Prepared in cooperation with the U.S. Department of Defense

\title{
Hydrogeologic Barriers to the Infiltration of Treated Wastewater at the Joint Base McGuire-Dix-Lakehurst Land Application Site, Burlington County, New Jersey
}

- Scientific Investigations Report 2016 5065 :

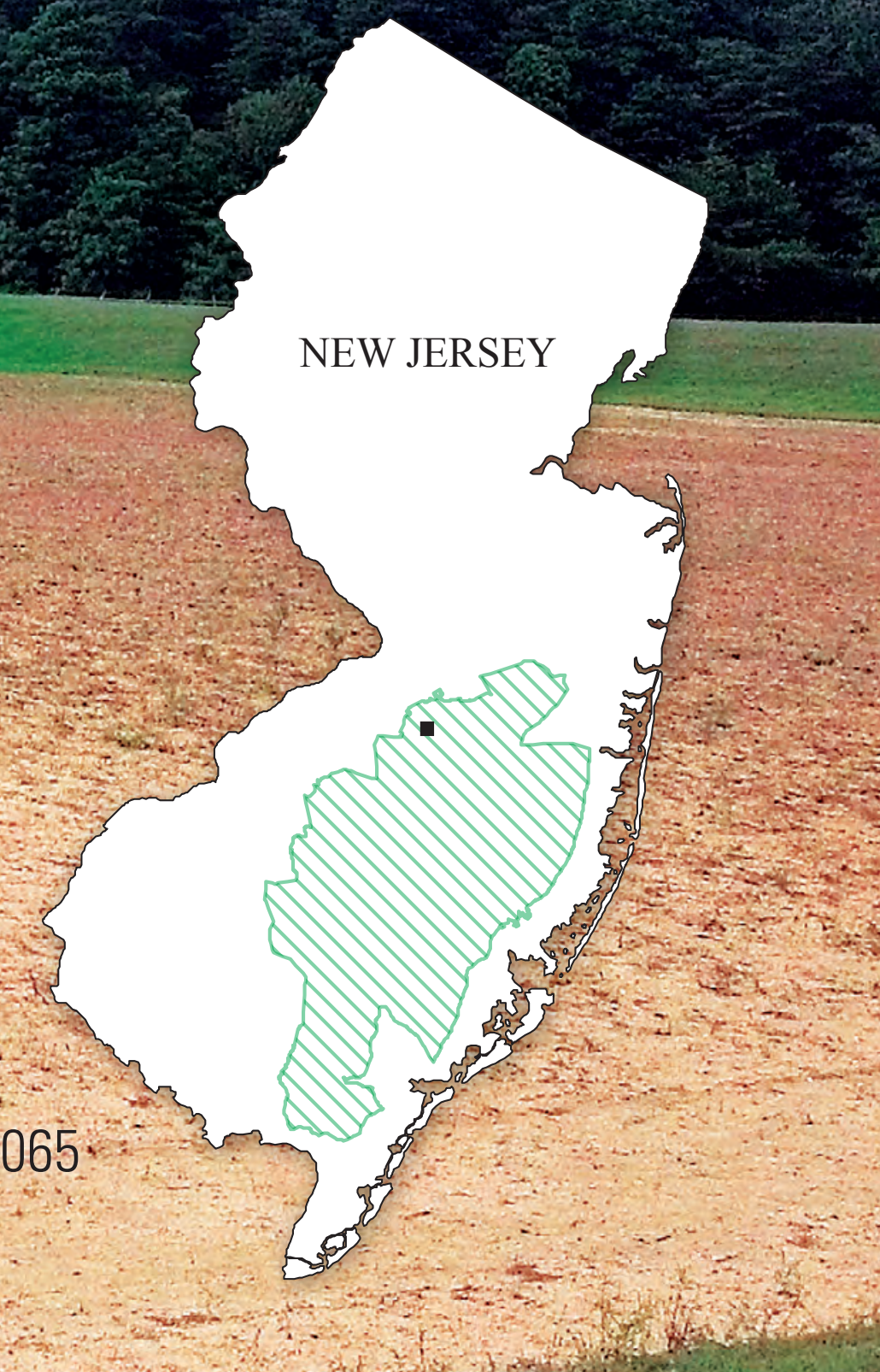


Cover. Map showing location of Joint Base McGuire-Dix-Lakehurst Land Application Site, New Jersey. Green shading represents extent of Pinelands National Reserve. Photograph showing infiltration basin A2, Joint Base McGuire-Dix-Lakehurst Land Application Site, New Jersey. 


\section{Hydrogeologic Barriers to the Infiltration of Treated Wastewater at the Joint Base McGuire-Dix-Lakehurst Land Application Site, Burlington County, New Jersey}

By Alex R. Fiore

Prepared in cooperation with the U.S. Department of Defense

Scientific Investigations Report 2016-5065 


\title{
U.S. Department of the Interior SALLY JEWELL, Secretary
}

\section{U.S. Geological Survey Suzette M. Kimball, Director}

\author{
U.S. Geological Survey, Reston, Virginia: 2016
}

For more information on the USGS - the Federal source for science about the Earth, its natural and living resources, natural hazards, and the environment—visit http://www.usgs.gov or call 1-888-ASK-USGS.

For an overview of USGS information products, including maps, imagery, and publications, visit http://www.usgs.gov/pubprod/.

Any use of trade, firm, or product names is for descriptive purposes only and does not imply endorsement by the U.S. Government.

Although this information product, for the most part, is in the public domain, it also may contain copyrighted materials as noted in the text. Permission to reproduce copyrighted items must be secured from the copyright owner.

Suggested citation:

Fiore, A.R., 2016, Hydrogeologic barriers to the infiltration of treated wastewater at the Joint Base McGuire-DixLakehurst Land Application Site, Burlington County, New Jersey: U.S. Geological Survey Scientific Investigations Report 2016-5065, 83 p., http://dx.doi.org/10.3133/sir20165065.

ISSN 2328-0328 (online) 


\section{Acknowledgments}

The author thanks Joint Base McGuire-Dix-Lakehurst for their support and cooperation.

The author also thanks Optech Monette, LLC, for ready access to the site, operational data, and engineering reports. James R. Degnan and Timothy J. Reilly of the U.S. Geological

Survey (USGS) provided valuable reviews that greatly improved this manuscript. Gratefully acknowledged are USGS colleagues Glen B. Carleton and Pierre J. Lacombe for their insightful discussions, and Jerilyn Collenburg, Eric Jacobsen, and Robert Rosman for their field assistance. 


\section{Contents}

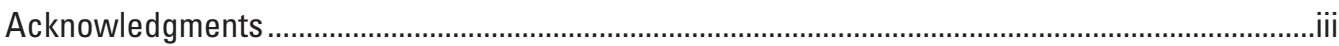

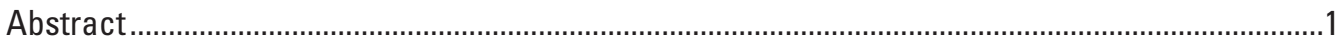

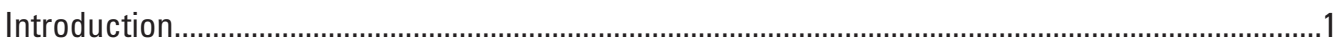

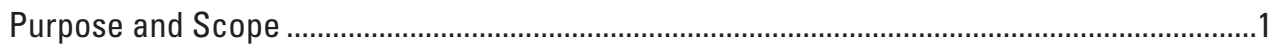

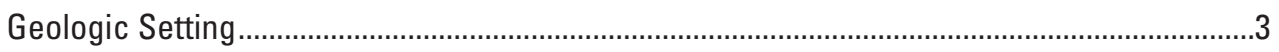

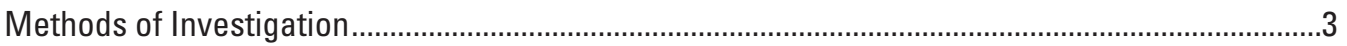

Borehole and Surface Geophysics ................................................................................

Sediment Collection and Analysis .......................................................................................

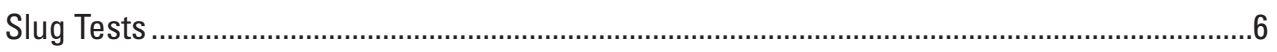

Groundwater-Level Measurements.................................................................................

Altitude Surveying.............................................................................................................

Assessment of Site Hydrogeology and Applic ability to Wastewater Infiltration Effectiveness.......7

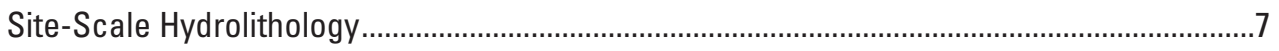

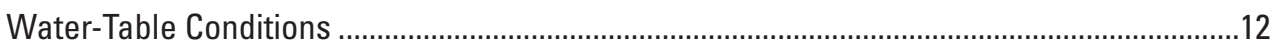

Intersection of Water Table with Basins B5 and B6 ....................................................12

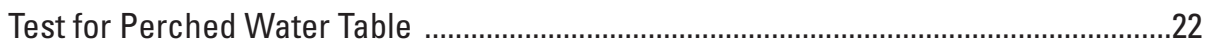

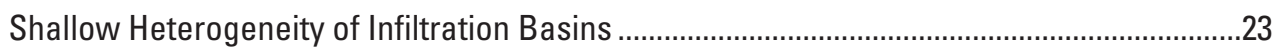

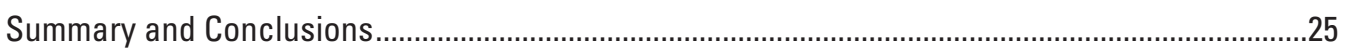

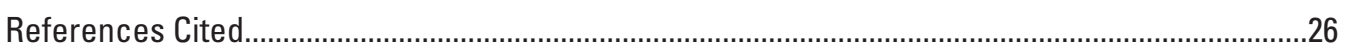

Appendix 1. Ground-penetrating radar profile images from the Joint Base McGuire-DixLakehurst Land Application Site, New Jersey .................................................................29

Appendix 2. Natural gamma logs of wells at the Joint Base McGuire-Dix-Lakehurst Land Application Site and vicinity, New Jersey.......................................................................

Appendix 3. Table of well construction and driller log descriptions from wells at the Joint Base McGuire-Dix-Lakehurst Land Application Site and vicinity, New Jersey .................57

Appendix 4. Normalized water-level displacement as a function of time during slug tests of piezometer wells at the Joint Base McGuire-Dix-Lakehurst Land Application Site, New Jersey, using Bouwer and Rice (1976) solution ................................................................63

Appendix 5. Table of discrete water-level altitudes in piezometer wells at the Joint Base McGuire-Dix-Lakehurst Land Application Site, New Jersey, as measured by site operators from January 2000-December 2014 ................................................................67

Appendix 6. Discrete water levels in piezometer wells at the Joint Base McGuire-DixLakehurst Land Application Site, New Jersey, as measured by site operators from January 2000-December 2014 


\section{Figures}

1. Map showing locations of wells, temporary auger borings, core sites, and transect sections at the Joint Base McGuire-Dix-Lakehurst Land Application Site, New Jersey...

2. Map showing surficial geology in the vicinity of the Joint Base McGuire-DixLakehurst Land Application Site, New Jersey...

3. Map showing locations of ground-penetrating radar survey lines at the Joint Base McGuire-Dix-Lakehurst Land Application Site, New Jersey..

4. Natural gamma log, well construction diagram, and driller log of MW-1D, Joint Base McGuire-Dix-Lakehurst Land Application Site, New Jersey..

5. Natural gamma log, well construction diagram, and driller log of MW-4D, Joint Base McGuire-Dix-Lakehurst Land Application Site, New Jersey.

6. Natural gamma log, well construction diagram, and driller log of MW-6D, Joint Base McGuire-Dix-Lakehurst Land Application Site, New Jersey.

7. Natural gamma log, well construction diagram, and driller log of MW-9D, Joint Base McGuire-Dix-Lakehurst Land Application Site, New Jersey.

8. Section $A-A$ ' showing natural gamma logs of MW-4D, PW-B6, PW-B5, and MW-8D, and depths of fine-grained material in the South Core, Joint Base McGuire-Dix-Lakehurst Land Application Site, New Jersey...

9. Photograph of ferric oxide stained sediment from North Core and muscovite mica-rich quartz sand from South Core, Joint Base McGuire-Dix-Lakehurst Land Application Site, New Jersey...

10. Map showing topography and estimated water-table contours in the vicinity of the Joint Base McGuire-Dix-Lakehurst Land Application Site, New Jersey.....

11. Section $B-B^{\prime}$ showing water levels in relation to infiltration basins $B 4$ and $B 6$, Joint Base McGuire-Dix-Lakehurst Land Application Site, New Jersey.

12. Section $C-C^{\prime}$ showing water levels in relation to infiltration basins $B 2$ and $B 4$, Joint Base McGuire-Dix-Lakehurst Land Application Site, New Jersey.

13. Section $D-D$ 's showing water levels in relation to infiltration basins $B 2$ and $B 5$, Joint Base McGuire-Dix-Lakehurst Land Application Site, New Jersey.

14. Photograph of seepage face flow structures on the berm between basin B5 and basin B2, Joint Base McGuire-Dix-Lakehurst Land Application Site, New Jersey ........21

15. Segment of ground-penetrating radar line 10 with interpreted reflections, Joint Base McGuire-Dix-Lakehurst Land Application Site, New Jersey...

16. Ground-penetrating radar line 33 in basin B5 with interpreted water table reflection, Joint Base McGuire-Dix-Lakehurst Land Application Site, New Jersey.

17. Ground-penetrating radar line 15 in basin B3 with interpreted reflections, Joint Base McGuire-Dix-Lakehurst Land Application Site, New Jersey. 


\section{Tables}

1. Water-level conditions and hydraulic conductivity estimates for wells at the Joint Base McGuire-Dix-Lakehurst Land Application Site, New Jersey, 2000-15..........13

2. Grain size analysis results as estimated by use of the wet sieve method through 74-micron mesh, Joint Base McGuire-Dix-Lakehurst Land Application Site, New Jersey...

3. Description of auger boring test holes and depth to water measurements, Joint Base McGuire-Dix-Lakehurst Land Application Site, New Jersey, April 2015. 


\section{Conversion Factors}

U.S. customary units to International System of Units

\begin{tabular}{|c|c|c|}
\hline Multiply & By & To obtain \\
\hline \multicolumn{3}{|c|}{ Length } \\
\hline inch (in.) & 2.54 & centimeter $(\mathrm{cm})$ \\
\hline inch (in.) & 25.4 & millimeter $(\mathrm{mm})$ \\
\hline foot $(\mathrm{ft})$ & 0.3048 & meter $(\mathrm{m})$ \\
\hline mile (mi) & 1.609 & kilometer $(\mathrm{km})$ \\
\hline \multicolumn{3}{|c|}{ Area } \\
\hline acre & 4,047 & square meter $\left(\mathrm{m}^{2}\right)$ \\
\hline acre & 0.4047 & hectare (ha) \\
\hline acre & 0.4047 & square hectometer $\left(\mathrm{hm}^{2}\right)$ \\
\hline acre & 0.004047 & square kilometer $\left(\mathrm{km}^{2}\right)$ \\
\hline square foot $\left(\mathrm{ft}^{2}\right)$ & 929.0 & square centimeter $\left(\mathrm{cm}^{2}\right)$ \\
\hline square foot $\left(\mathrm{ft}^{2}\right)$ & 0.09290 & square meter $\left(\mathrm{m}^{2}\right)$ \\
\hline \multicolumn{3}{|c|}{ Volume } \\
\hline ounce, fluid (fl. oz) & 0.02957 & liter (L) \\
\hline pint (pt) & 0.4732 & liter $(\mathrm{L})$ \\
\hline quart (qt) & 0.9464 & liter $(\mathrm{L})$ \\
\hline gallon (gal) & 3.785 & liter (L) \\
\hline cubic inch $\left(\mathrm{in}^{3}\right)$ & 0.01639 & liter $(\mathrm{L})$ \\
\hline \multicolumn{3}{|c|}{ Flow rate } \\
\hline foot per day (ft/d) & 0.3048 & meter per day $(\mathrm{m} / \mathrm{d})$ \\
\hline million gallons per day $(\mathrm{Mgal} / \mathrm{d})$ & 0.04381 & cubic meter per second $\left(\mathrm{m}^{3} / \mathrm{s}\right)$ \\
\hline \multicolumn{3}{|c|}{ Mass } \\
\hline ounce, avoirdupois (oz) & 28.35 & $\operatorname{gram}(\mathrm{g})$ \\
\hline \multicolumn{3}{|c|}{ Hydraulic conductivity } \\
\hline foot per day (ft/d) & 0.3048 & meter per day $(\mathrm{m} / \mathrm{d})$ \\
\hline \multicolumn{3}{|c|}{ Geologic gradient } \\
\hline foot per mile (ft/mi) & 0.1894 & meter per kilometer $(\mathrm{m} / \mathrm{km})$ \\
\hline
\end{tabular}

\section{Datum}

Vertical coordinate information is referenced to the National Geodetic Vertical Datum of 1929 (NGVD 29).

Horizontal coordinate information is referenced to the North American Datum of 1983 (NAD 83).

Altitude, as used in this report, refers to distance above the vertical datum. 


\section{Abbreviations}

BLS below land surface

DC direct current

GPR ground-penetrating radar

JBMDL Joint Base McGuire-Dix-Lakehurst

$\mathrm{K} \quad$ hydraulic conductivity

LAS land application site

USGS U.S. Geological Survey 


\title{
Hydrogeologic Barriers to the Infiltration of Treated Wastewater at the Joint Base McGuire-Dix-Lakehurst Land Application Site, Burlington County, New Jersey
}

\author{
By Alex R. Fiore
}

\section{Abstract}

For the final phase of wastewater treatment operations at Joint Base McGuire-Dix-Lakehurst in Burlington County, New Jersey, treated effluent is pumped to 12 infiltration basins on a Land Application Site to recharge the unconfined Kirkwood-Cohansey aquifer system. Two of the 12 infiltration basins are operationally ineffective because discharged effluent fails to percolate and remains ponded on the basin surfaces. A study conducted by the U.S. Geological Survey, in cooperation with the U.S. Department of Defense, investigated the potential hydrogeologic conditions preventing infiltration in these basins by testing the geophysical, lithological, and hydraulic characteristics of the aquifer material underlying the site. Saturated sand, sandy clay, and unsaturated sand were encountered in succession through the upper 4 feet of sediment below land surface at the two ineffective basins. Water levels in auger borings penetrating the clay and underlying dry sand were measured as deeper than water levels in nested auger borings in the saturated sand overlying the clay, which indicates a downward vertical gradient was established after removal of the clay in the deeper borings created a conduit for drainage from the surficial saturated sands. Ground-penetrating radar surveys and additional water levels measured in piezometer wells adjacent to the infiltration basins indicated a lack of connectivity between the ponded basin water and the regional water table, and demonstrated that perched conditions were not present in native formation materials outside the inoperable basins. Therefore, the near-surface low permeability clay is likely preventing infiltration from the basin surface and causes the ineffectiveness of the two basins for wastewater land application operations.

\section{Introduction}

The wastewater treatment system of Joint Base McGuireDix-Lakehurst (JBMDL) in Burlington County, New Jersey, incorporates a Land Application Site (LAS) as the final phase of the treatment process. Following disinfection at a treatment plant, wastewater effluent is pumped to infiltration basins at the LAS, inducing recharge to groundwater. Twelve infiltration basins, numbered A1 through A6 and B1 through B6, were built at the LAS for this purpose (fig. 1). Basins vary in area from about 3.5 to 5 acres and are enclosed by constructed soil berms that vary in height from less than 6 to more than 25 feet (ft). Wastewater effluent discharges into the basins through outfalls, and each basin is paired with another through spillways carved into the berms. Effluent is discharged until the basin water level reaches a few feet height, whereupon an empty basin is chosen at the discretion of the site operator to receive the effluent (Optech Monette, LLC., written commun., 2014).

Two of the 12 basins (B5 and B6) quickly became saturated following construction of the LAS in the mid-1990s and are considered unsuitable for wastewater infiltration; the remaining 10 basins exhibited varying rates of drainage effectiveness (Optech Monette, LLC., written commun., 2014). The full permitted capacity of the LAS is 4.6 million gallons per day (Mgal/d), but currently (2015) about $2 \mathrm{Mgal} / \mathrm{d}$ is recharged to groundwater through the treatment system. The LAS can adequately handle $2 \mathrm{Mgal} / \mathrm{d}$, but the ineffective performance of basins B5 and B6 may cause capacity issues for the treatment system if the wastewater quantity handled by the treatment plant is increased. The discharge of wastewater effluent into surface water is prohibited owing to the location of JBMDL in the Pinelands National Reserve (New Jersey Pinelands Commission, 2014), so understanding the hydrogeology of the LAS is the first step in assessing the current and prospective capabilities of the LAS for sustained recharge of treated wastewater into groundwater. Therefore, a study was conducted by the U.S. Geological Survey (USGS), in cooperation with the U.S. Department of Defense, to evaluate the hydrogeologic conditions leading to the ineffective infiltration performance of basins B5 and B6.

\section{Purpose and Scope}

This report summarizes results of an investigation to document the hydrogeologic factors that may inhibit wastewater infiltration at 2 of the 12 basins at the LAS and cause different 


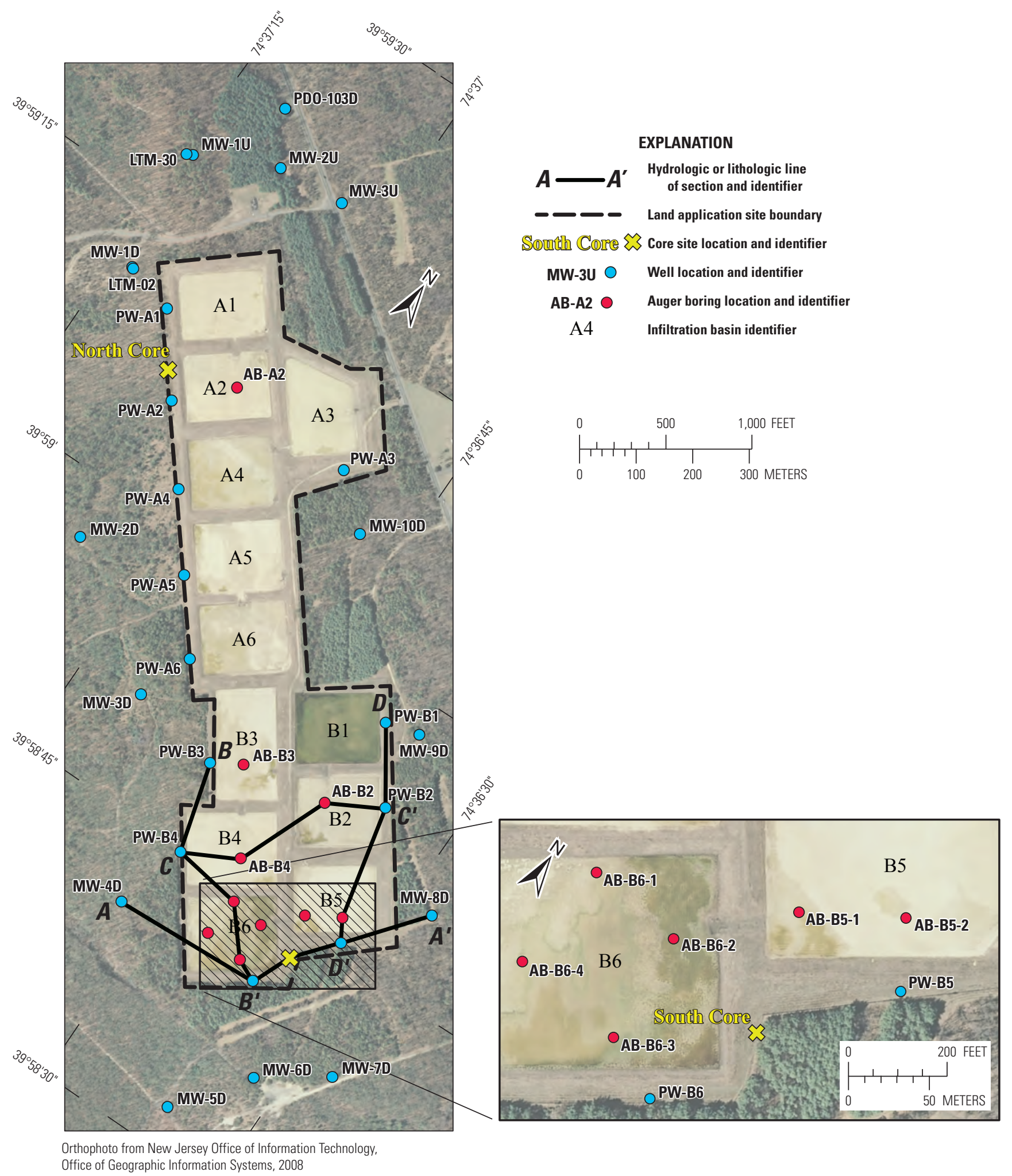

Figure 1. Locations of wells, temporary auger borings, core sites, and transect sections at the Joint Base McGuire-Dix-Lakehurst Land Application Site, New Jersey. 
rates of infiltration in the 10 functioning basins. The investigation seeks to determine whether the different infiltration rates can be explained by conditions such as the intersection of the regional water table with topographically low basins, local hydrogeologic conditions such as perched water tables associated with low permeability clays, and (or) construction-related differences of the basins. Material from this report will inform an ongoing study to test whether present site conditions can sustain infiltration at the full $4.6 \mathrm{Mgal} / \mathrm{d}$ rate.

\section{Geologic Setting}

The JBMDL LAS covers nearly 100 acres within the New Jersey Coastal Plain Physiographic Province (fig. 2). The Coastal Plain consists of unconsolidated sands and clays of Cretaceous to Holocene age that dip toward the southeast (Owens and Minard, 1964; Zapecza, 1989; Owens and others, 1999). The LAS is located where the middle Mioceneage Cohansey Formation and Pleistocene and Holocene-age alluvium, colluvium, and lag gravels constitute the surficial sediments (fig. 2) (Owens and Minard, 1964; Newell and others, 2000). The Cohansey Formation consists primarily of sand with discontinuous lenses of clay (Owens and Minard, 1964; Zapecza, 1989; Sugarman and others, 2005). In outcrop, the Cohansey sands are weathered to an orange-yellow color distinguishable from the unweathered light beige/gray of the sands at depth (Owens and Minard, 1964; Newell and others, 2000; Sugarman and others, 2005). The Cohansey Formation unconformably overlies the lower Miocene-age Kirkwood Formation, specifically the lower member that consists of massive bedded gray and dark brown very fine to fine sand and silt (Minard and Owens, 1963). An auger hole drilled about 1 mile northwest of the LAS during a previous study (Minard and Owens, 1963) revealed the contact between the formations at about $35 \mathrm{ft}$ below land surface (BLS), and another auger hole about 1 mile southeast of the LAS from a different study (Owens and Minard, 1964) revealed the contact at about $20 \mathrm{ft}$ BLS. The formations (and contact) dip between 8 and $20 \mathrm{ft}$ per mile southeastward in the study area (Owens and Minard, 1964; Minard and Owens, 1963).

The Kirkwood-Cohansey aquifer system is an important unconfined aquifer in the region (Zapecza, 1989; Sugarman and others, 2005) and is the aquifer to which the LAS wastewater effluent recharges. A thickness of $50 \mathrm{ft}$ is estimated for the aquifer in this area (Zapecza, 1989; Watt and others, 2002). Semi-confined conditions and perched water tables that can be present locally in the Kirkwood-Cohansey aquifer system (Zapecza, 1989) have been identified as inhibitors of wastewater infiltration at other facilities in the Coastal Plain (Reilly and others, 2010).

Pleistocene and Holocene sediments overlying the Cohansey Formation accumulate within alluvial valleys or atop topographic highs (Owens and Minard, 1964; Newell and others, 2000). Owens and Minard (1964) report thicknesses of 4 and 5 feet for these deposits at two specific locations within 1 mile of the LAS and consider Miocene formations to be exposed where younger sediments are less than $3 \mathrm{ft}$ thick. Throughout the entire New Jersey Coastal Plain, these deposits are generally less than $7 \mathrm{ft}$ thick but can be present locally up to about $26 \mathrm{ft}$ thick (Newell and others, 2000).

\section{Methods of Investigation}

Borehole and surface geophysics, slug tests, sediment analysis, and water-level measurements were used in the investigation to identify zones of relative low permeability beneath basins. The methods are described below.

\section{Borehole and Surface Geophysics}

Ground-penetrating radar (GPR) data were collected along survey lines to obtain radar reflection profiles of the subsurface beneath the LAS. GPR equipment consists of a control unit, a transmitter antenna that emits a radio-frequency electromagnetic pulse into the subsurface, and a receiver antenna that collects its reflected signal. The reflections occur as the emitted radio wave encounters an interface between earth materials of contrasting electromagnetic properties, including electrical conductivity and dielectric permittivity (Beres and Haeni, 1991). Wave velocity slows and signal attenuation increases in materials of high electrical conductivity and large dielectric constant. Increased attenuation lessens the depth penetration of the emitted pulse. Strong wave reflections occur at interfaces where the contrast is high, such as from unsaturated to saturated sediment and sand to clay. Data acquired are recorded on a computer as the GPR unit is towed across the ground surface.

The GPR unit used in this study was a 100 megahertz shielded antenna by MALÅ Geoscience $\AA$. Thirty-three lines were surveyed at the LAS along southwest-northeast or northwest-southeast orientations (fig. 3). One set of 10 lines was surveyed along the outer perimeter of the LAS along a chain-link fence. The antenna was pulled at a constant distance parallel to the fence so that any interference caused by the fence would be equally maintained throughout each perimeter line. The remaining 23 lines were surveyed within basins A2, A3, A4, A5, A6, B1, B2, B3, B4, and B5. Basins A1 and B6 had too much standing water at the time of the survey to safely obtain data without damaging the equipment. Similarly, some standing water in basins A2, B3, and B4, although less extensive, allowed for fewer lines surveyed; surveys were performed along the periphery of those basins where ponding was relatively minimal. A direct current (DC) removal filter with 660 start sample for calculation was applied to all GPR data. Uninterpreted GPR profiles are provided in appendix 1, with no assumed ground velocity because of a lack of calibration targets. 


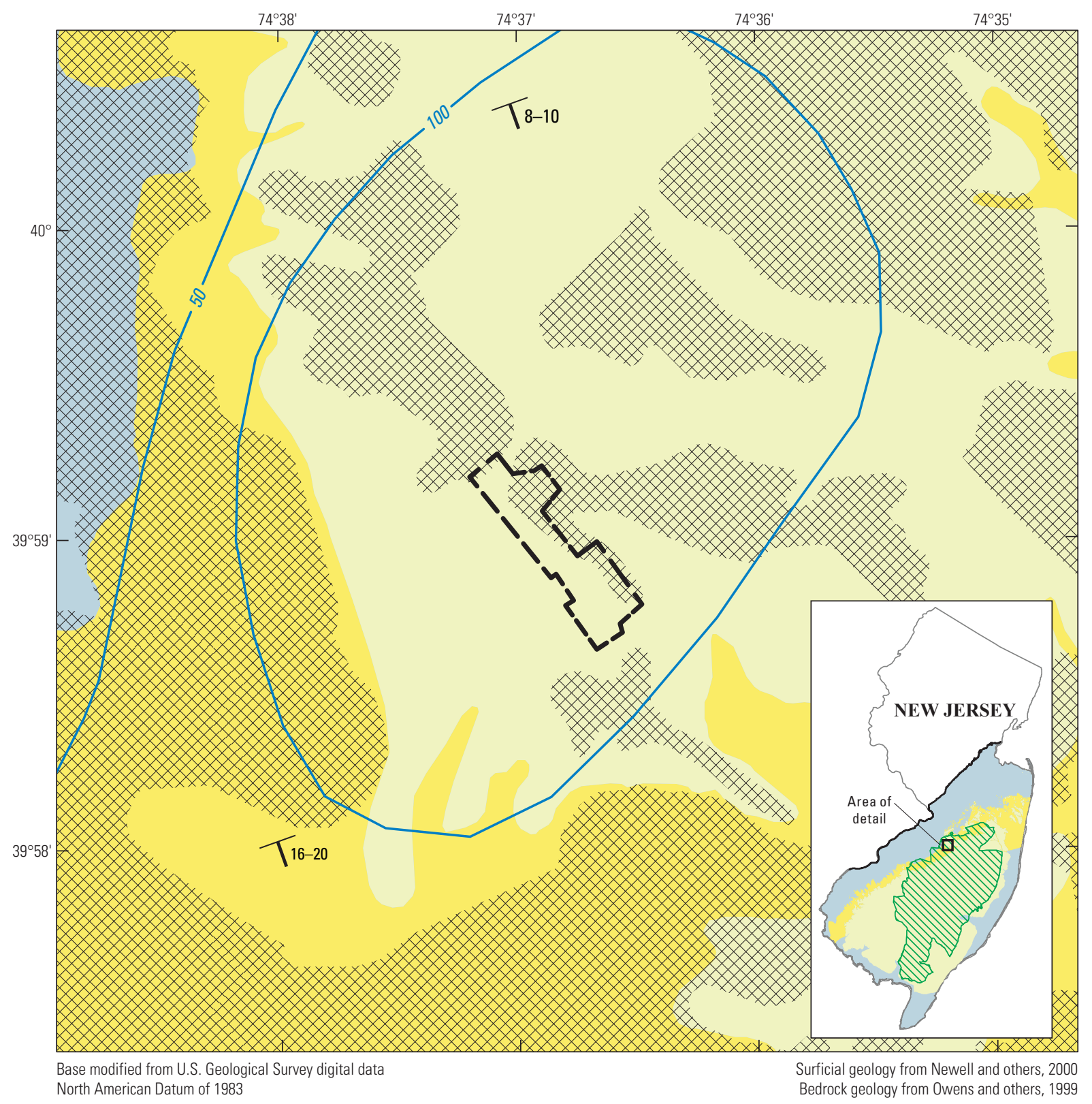

EXPLANATION

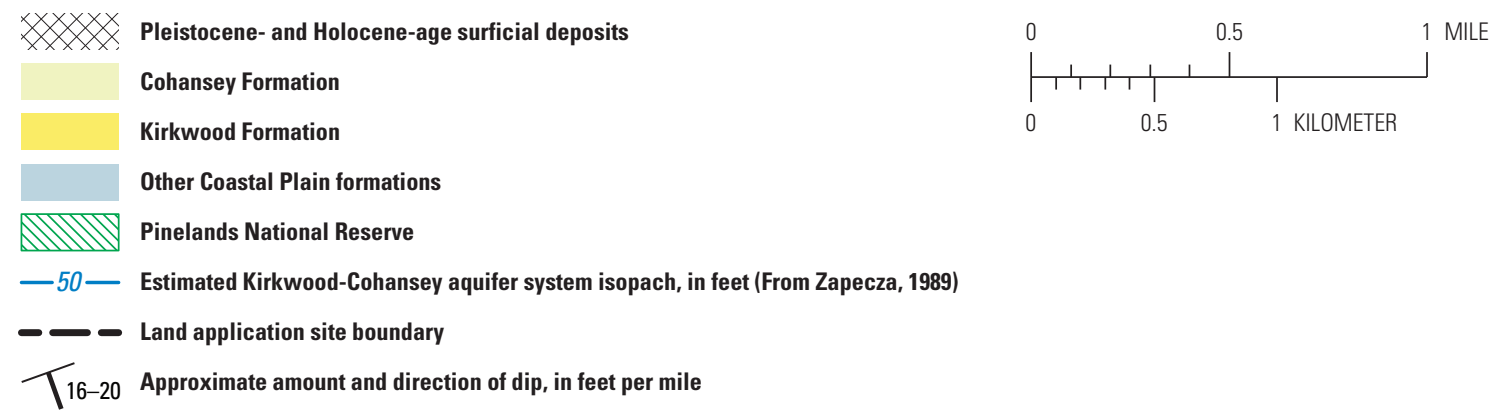

Figure 2. Surficial geology in the vicinity of the Joint Base McGuire-Dix-Lakehurst Land Application Site, New Jersey. 


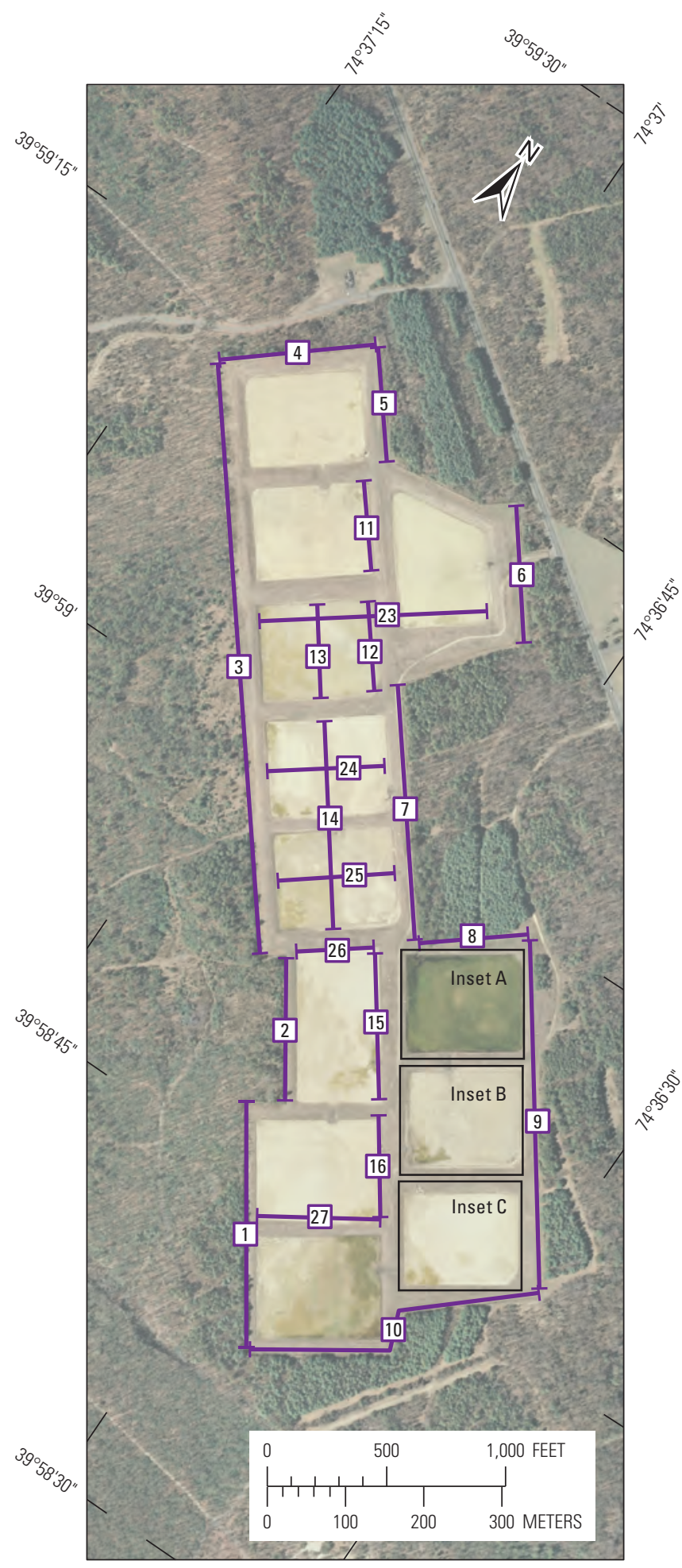

EXPLANATION

-32] $\begin{gathered}\text { Raw ground-penetrating radar } \\ \text { line and identifier }\end{gathered}$
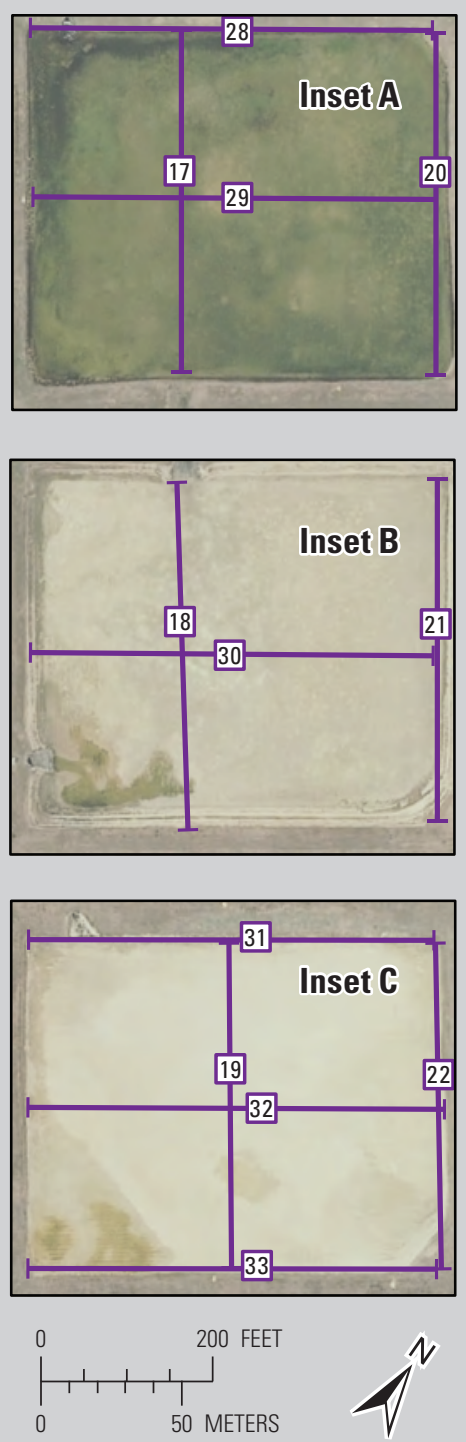

Orthophoto from New Jersey Office of Information Technology, Office of Geographic Information Systems, 2008

Figure 3. Locations of ground-penetrating radar survey lines at the Joint Base McGuire-Dix-Lakehurst Land Application Site, New Jersey. 
Natural-gamma logs were collected to identify the lithology of sediments underlying the LAS. A gamma log is collected by lowering a probe down a borehole with a winch that is connected to a logger and laptop at land surface. The probe records the amount of natural gamma radiation emitted by the sediments immediately surrounding the borehole. Clays generally contain relatively larger quantities of the high gamma emitting radioisotope potassium- 40 than sands and gravels. Therefore, higher gamma counts in a log generally correspond to clays and lower gamma counts to sands or gravels (Keys, 1990).

The logging system used in this study was a Mount Sopris ${ }^{\circledR}$ MGXII logger and winch and a 2 PGA-1000 gamma tool. Logs were collected from the 12 on-site piezometer wells (PW-A1, PW-A2, PW-A3, PW-A4, PW-A5, PW-A6, PW-B1, PW-B2, PW-B3, PW-B4, PW-B5, and PW-B6), the 13 offsite monitoring wells (MW-1U, MW-2U, MW-3U, MW-1D, MW-2D, MW-3D, MW-4D, MW-5D, MW-6D, MW-7D, MW-8D, MW-9D, and MW-10D), and 3 additional off-site wells nearby (LTM-02, LTM-30, and PDO-103D) (fig. 1). Gamma logs from this study are provided in appendix 2 .

\section{Sediment Collection and Analysis}

Two sediment cores were collected with a Geoprobe ${ }^{\circledR}$ Macro-Core Soil Sampler to identify finer-grained layers that may impede infiltration. Core sites were selected on opposite sides of the LAS (fig. 1) for geographic disparity, and outside basins and off berms to obtain sediments most closely representative of native lithology. Additional sediment samples were collected with a hand auger through the first 3-5 feet below the bottoms of basins A2, B2, B3, B4, B5, and B6 (fig. 1) in approximately 1-ft bulk intervals. One auger boring was installed per basin in A2, B2, B3, and B4; two borings were installed in B5; and four borings were installed in B6. These additional borings in $\mathrm{B} 5$ and $\mathrm{B} 6$ were added to test for possible heterogeneity in the shallow sediments, depending on location in the basin. Each auger boring was a temporary fixture refilled with the excavated sediments at the end of the field day.

A wet sieve analysis was performed to obtain approximations of percentages of clay/silt and sand. Approximately 50 grams of representative sediment samples were extracted from each auger interval and core. Large pebbles and organic matter, such as plant roots, were removed from larger bulk samples to avoid overestimation of mass if they were included in a representative sample. Samples were air dried in a vent hood, then weighed to obtain a dry mass prior to sieving. Samples were then treated with a 40 -gram per liter deflocculant solution of sodium hexametaphosphate (ASTM, 2007) to disperse clays into suspension and break up "clumps" that may not otherwise have passed through a sieve. Samples were then wet-sifted through a 74-micron sieve. Sediments passing through a 74-micron mesh represent silt-and clay-sized particles; those retained are sand and gravel. Retained sediments were again air dried in a vent hood and weighed to obtain post-sieving mass. A combined clay and silt percentage was calculated by subtracting the mass of the retained sediment from the total mass before sieving, then dividing by the total mass and multiplying by 100 . The division between clay and silt texture was not tested.

Verbatim descriptions of drill cuttings logged by the well drillers and official well-record specified construction information (Optech Monette, LLC, written commun., 2014; New Jersey Department of Environmental Protection, written commun., 2015) are included in appendix 3 . The descriptions in appendix 3 are identical to those provided by drillers to avoid misinterpretation and assumptions for abbreviations used by the drillers for lithology. Where not specified outright in the record, depths of cutting intervals and well features were estimated from the information provided. Accuracy of well records and driller-provided information is dubious and was not verified by the USGS.

\section{Slug Tests}

Slug tests were performed in on-site piezometer wells to evaluate the hydraulic properties of the aquifer surrounding the wells adjacent to the basins. The slug tests followed standard USGS methods (Cunningham and Schalk, 2011). Slug tests consist of two parts, a falling head or "slug-in" test and a rising head or "slug-out" test. A slug-in test is performed by instantaneously inserting a solid object (slug) below the water level in a well, causing the water level to rise, then measuring the recovery time for return to its initial static position. Then, a slug-out test is performed by instantaneously removing the slug from the well, causing the water level to fall, then again measuring recovery time of the water level to return to its initial static position. The nature of the water-level recovery can be used to estimate hydraulic conductivity $(\mathrm{K})$ or transmissivity. LAS piezometer wells were tested with a polyvinyl chloride slug designed for $2 \mathrm{ft}$ of water-level displacement (measuring about 1.6 inches in diameter by $3.12 \mathrm{ft}$ in length), and water levels were monitored with an In-Situ ${ }^{\circledR}$ Level Troll 500 pressure transducer recording at 0.5 second intervals for the duration of each test. Each pre-test water level was at least $3 \mathrm{ft}$ above the top of the screen, so all 2-ft displacements were entirely within the casing. PW-B2 was dry and not tested. All tests were repeated at least twice to ensure each well was properly developed and $\mathrm{K}$ estimates were consistent. Smaller volume slugs were also used to ensure consistency in $\mathrm{K}$ estimates given different displacements. Slug-out test results are reported rather than slug-in test results because a slug is removed from a well with less splashing and less noise in transducer readings compared to slug insertion when using this method (Fiore, 2014). A correction for the frictional loss effects from the transducer and cable (Butler, 2002) was applied to the results after processing. 
Various methods exist to estimate $\mathrm{K}$ from slug test data. The analytical solution method of Bouwer and Rice (1976) was deemed appropriate for LAS slug tests because it was designed for unconfined aquifers such as the KirkwoodCohansey aquifer system and allows for the partially penetrating depths of LAS piezometer wells, assuming an aquifer thickness of 50-100 $\mathrm{ft}$ for the Kirkwood-Cohansey aquifer system in the study area (fig. 2) (Zapecza, 1989; Watt and others, 2002). This method also requires an assumption of finite well diameters, which was assumed to be met by LAS piezometer wells. The recorded data fit the solution well (appendix 4), which confirms Bouwer and Rice (1976) as an adequate choice for analysis. However, because of assumptions and the neglect of well bore storage and specific yield in the computation of K by the Bouwer and Rice (1976) method, K values are reported to one significant figure per USGS recommendations (Cunningham and Schalk, 2011) and are to be considered order-of-magnitude estimates.

\section{Groundwater-Level Measurements}

Discrete groundwater levels measured by USGS personnel in 2014 and 2015 using standardized procedures (Cunningham and Schalk, 2011), and monthly measurements recorded by LAS site operators in piezometer wells from 2000 to 2014 (appendix 5, 6) (Optech Monette, LLC, written commun., 2015), were evaluated to determine the range of possible water levels for each piezometer well at the LAS. Maximum, mean, and minimum water levels for each piezometer well were evaluated. The water table often falls below the bottom of the well screen of PW-B2, making a water-level measurement impossible, so the mean and lowest water levels cannot be calculated at that location. Water levels in off-site monitoring wells are not included in the monthly measurements by the site operator, so those sites were omitted from the analysis as a result of a lack of data. All USGS-acquired water levels in wells were measured with an electric tape. Water levels in temporary auger borings were measured with a steel tape. Water levels measured by USGS are stored in the USGS National Water Information System database. Operator-measured water levels are provided in appendix 5. Hydrographs of these water levels created for each piezometer well are included in appendix 6 .

\section{Altitude Surveying}

Previously surveyed altitudes for piezometer wells, monitoring wells, and basin bottoms used by site operators are also used in this report for consistency (Optech Monette, LLC, written commun., 2014). Relative altitudes of the two core sites and the auger borings in basin $\mathrm{B} 6$ were acquired by differential leveling. Horizontal coordinates of wells, borings, and core sites were measured with a consumer-grade global positioning system with $\pm 10 \mathrm{ft}$ accuracy.

\section{Assessment of Site Hydrogeology and Applicability to Wastewater Infiltration Effectiveness}

Results of the investigation and discussions of the potential effects of LAS hydrogeology on the infiltration of treated wastewater effluent are discussed in this section.

\section{Site-Scale Hydrolithology}

Short high gamma count intervals recorded in numerous logs give the appearance of numerous discontinuous clay lenses beneath the LAS, but information from well records conflicts with this interpretation. Well construction records show that a bentonite seal about 1-3 ft thick was grouted above the gravel pack in numerous wells. Some gamma "spikes" occur at depths similar to that of the bentonite grout (fig. 4-7; appendix 2), which can contain more potassium-40 and produce higher gamma emissions than the surrounding formation material, creating anomalous high gamma artifacts associated with well construction rather than native features. In addition, bentonite was mixed with cement to grout the annular space above the seal, which may further obscure the signal of gamma emissions from the natural formation material, making proper interpretation of the gamma logs problematic. Examples of this issue are exemplified in the logs of wells shown in figures 4-7. MW-1D has a gamma "spike" that correlates very well to the depth of the bentonite seal (fig. 4). MW-4D does as well, but the driller log indicated gray silt at a depth of about $14 \mathrm{ft}$ (fig. 5) that could potentially produce high gamma counts also. The MW-6D driller log indicates gray sandy clay at a depth of about $8 \mathrm{ft}$ that does not appear to produce significantly higher gamma counts despite its description (fig. 6), and MW-9D has two "spikes" that do not correlate to the reported bentonite seal depth, which did not appear to produce high gamma in that log (fig. 7). The differing responses on the LAS gamma logs indicate high heterogeneities in lithology and (or) well completion materials that cannot be differentiated with gamma analysis alone, so these gamma logs are not appropriate for use in lithologic interpretation for this study.

Gamma counts in the screened intervals of each well are less influenced by the bentonite in the annular space behind the casing and are likely more representative of natural formation properties. Casing muting effects on gamma counts (Keys, 1990) are likely consistent throughout the borehole for the LAS wells, assuming negligible differences of the effect from casings versus screens. Therefore, the absence of bentonite in the filter pack behind the screen will allow for greater gamma penetration in those intervals as the probe moves farther from the casing. An increase of gamma counts with depth occurs within the screens of wells adjacent to the infiltration basins. However, slug tests and cores indicate the gamma 


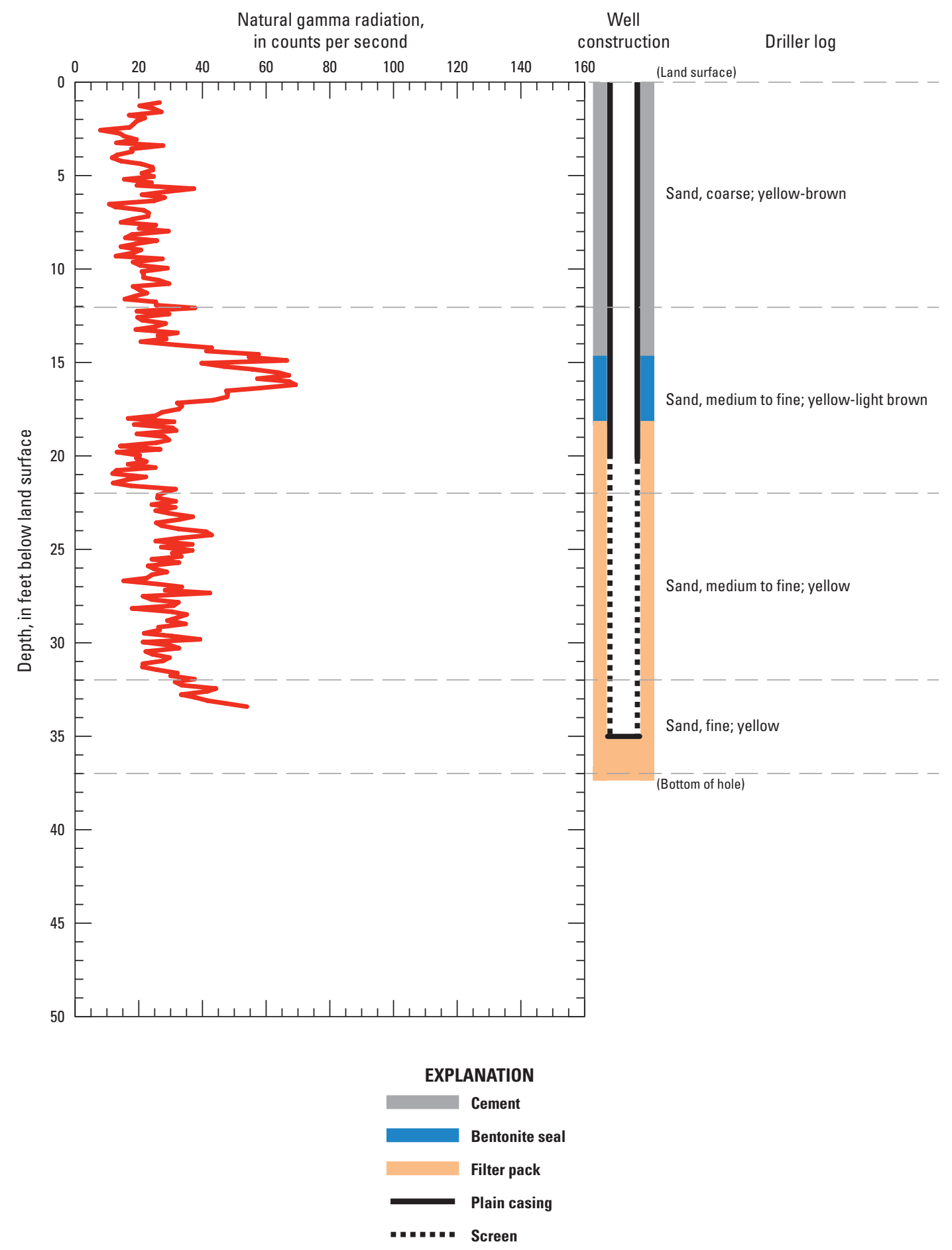

Figure 4. Natural gamma log, well construction diagram, and driller log of MW-1D, Joint Base McGuireDix-Lakehurst Land Application Site, New Jersey. 


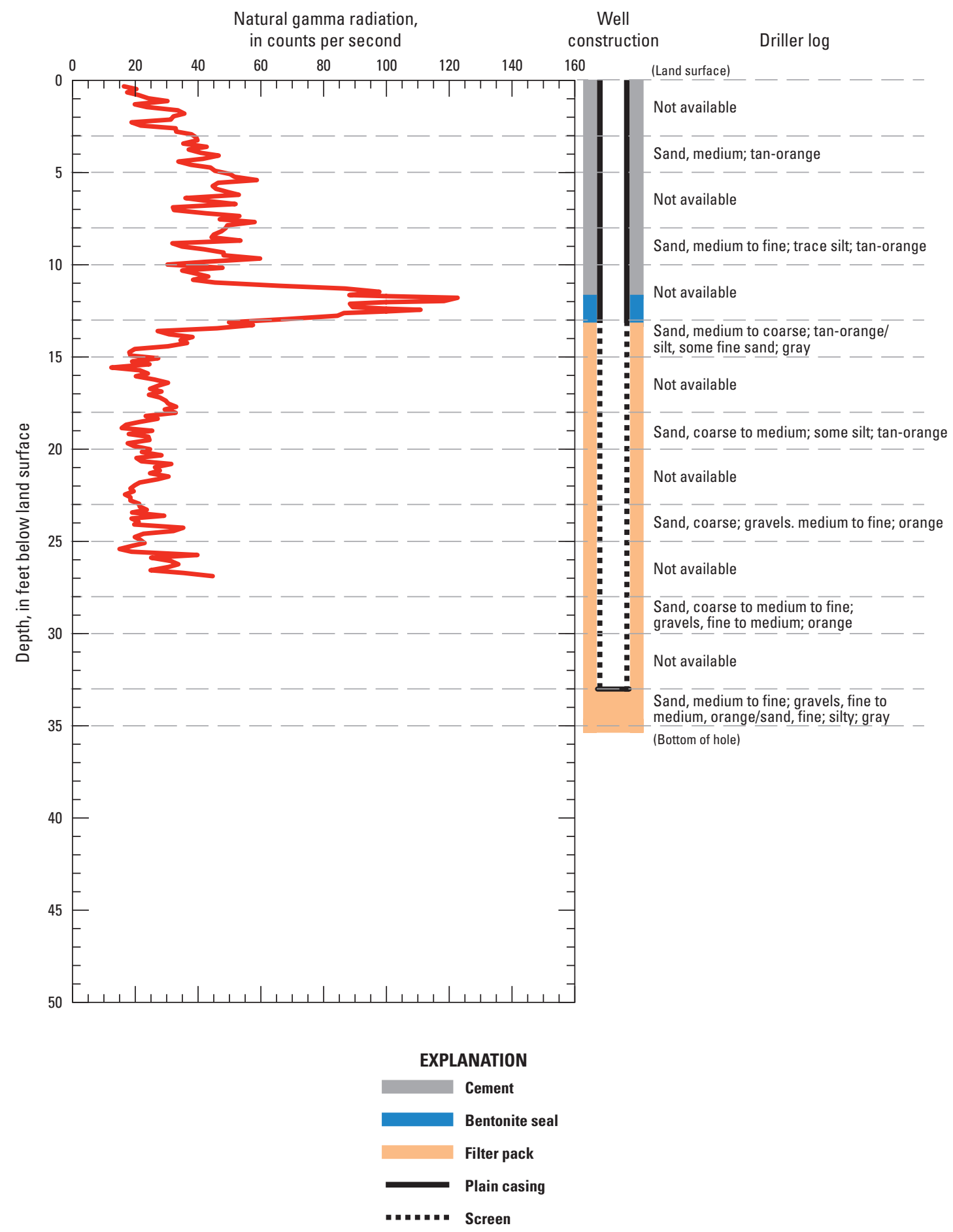

Figure 5. Natural gamma log, well construction diagram, and driller log of MW-4D, Joint Base McGuire-DixLakehurst Land Application Site, New Jersey. 


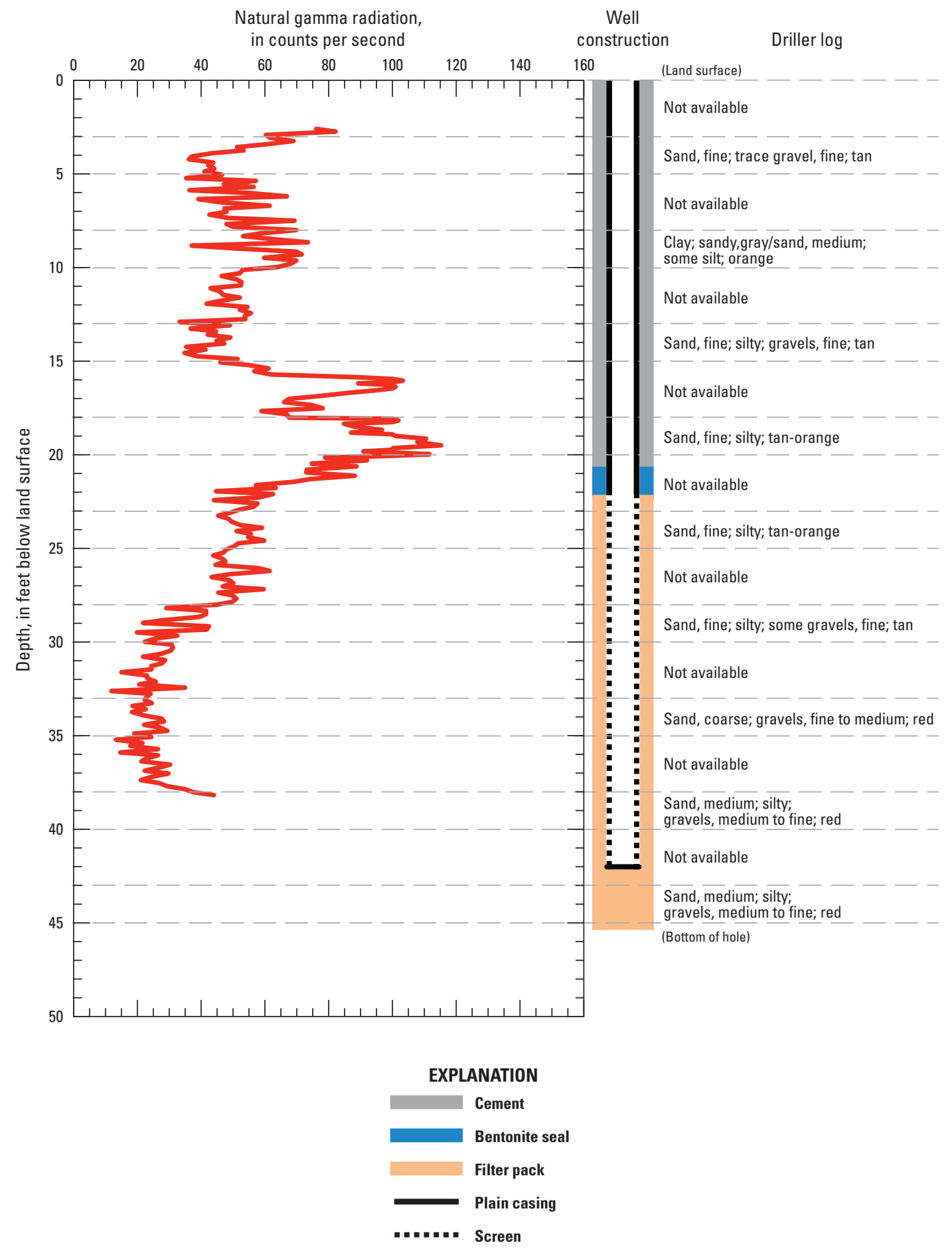

Figure 6. Natural gamma log, well construction diagram, and driller log of MW-6D, Joint Base McGuireDix-Lakehurst Land Application Site, New Jersey. 


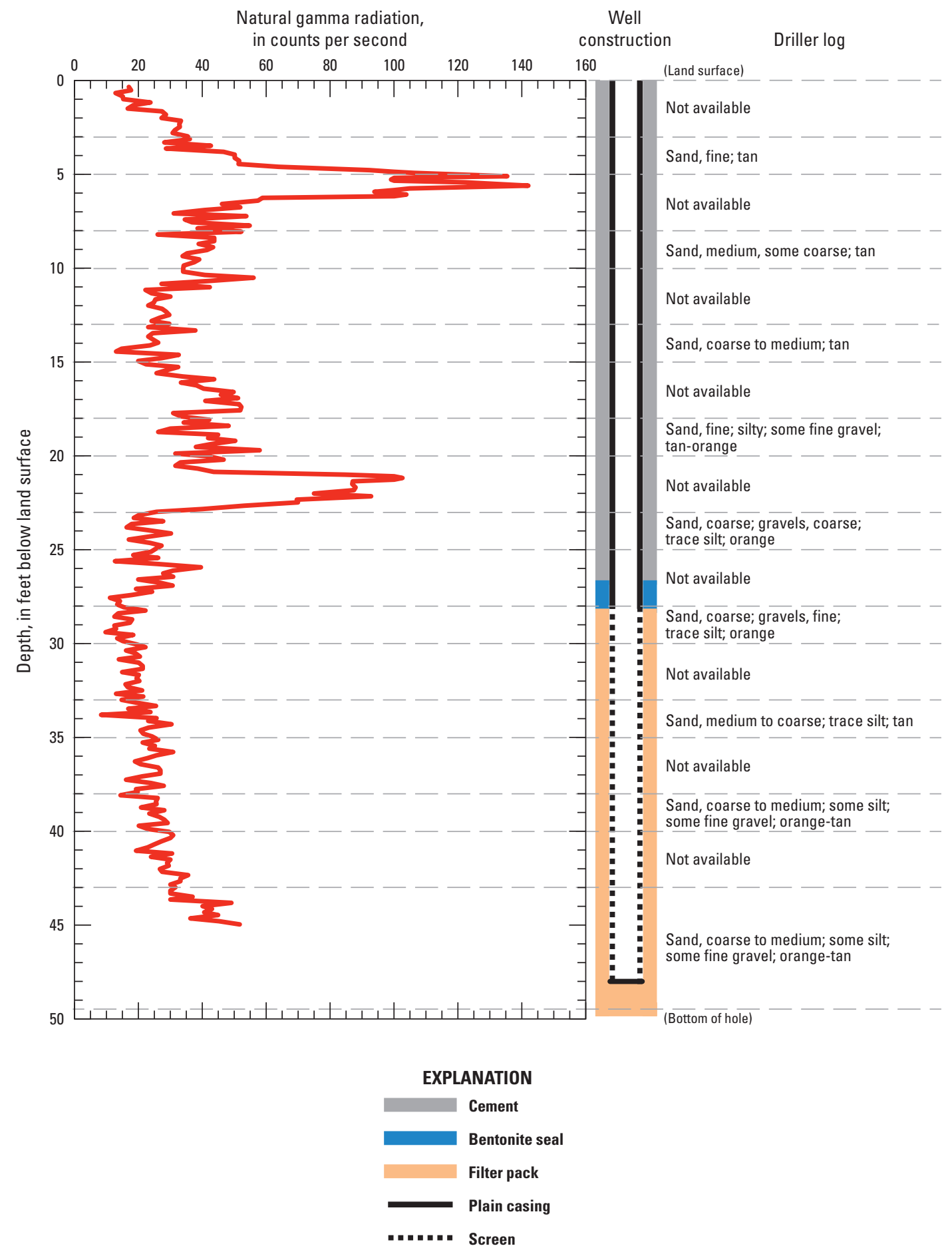

Figure 7. Natural gamma log, well construction diagram, and driller log of MW-9D, Joint Base McGuireDix-Lakehurst Land Application Site, New Jersey. 
changes are likely not associated with textural changes. For example, the slug tests of PW-A1 returned the lowest estimated $\mathrm{K}$ of $1 \mathrm{ft} /$ day despite low gamma counts, whereas PW-B3 returned a $\mathrm{K}$ of $60 \mathrm{ft} /$ day despite high gamma counts (table 1). K estimates at LAS piezometer wells differ across an order of magnitude, but all $\mathrm{K}$ estimates are within the typical $\mathrm{K}$ range for sand-size material (Halford and Kuniansky, 2002). Therefore, high gamma counts may be associated with mineralogy, such as high mica content within the sand. Minard and Owens (1963) describe the Kirkwood Formation in the study area as rich in muscovite mica, of which potassium is a major constituent. The gamma logs may be recording high gamma emissions from radioactive potassium-40 in muscovite at those depth intervals, the tops of which may also represent the unconformity between the Kirkwood Formation and overlying Cohansey Formation with less mica (Minard and Owens, 1963), but this contact likely has negligible hydraulic influence on the groundwater system beneath the LAS.

Two units of apparent fine-grained material recovered in the South Core between basins B5 and B6 at depth intervals of 7.5-9.9 ft and 15.75-17.2 ft appear to correlate to intervals of high gamma counts above the screened intervals of PW-B5 and PW-B6 (fig. 8). No fine sediments were recovered in the North Core between PW-A1 and PW-A2 where gamma counts are lower. South Core sediment samples from 7.9 to $8.0 \mathrm{ft}$ and 15.9 to $16.1 \mathrm{ft}$ in the apparent fine-grained units consist of about 75 percent (\%) and $89 \%$ sand post-sieve analysis, respectively (table 2). These sand percentages are generally indicative of higher permeability material (Schoeneberger and others, 2012). Sediment samples were sieved only to bulk sand and were not divided further within the range of sand sizes, so the fine-grained appearance of the South Core samples is likely relative to coarser sands above and below. A notable difference between the bulk sand-sized fraction of the North Core and South Core is that the North Core has more ferric iron-oxide staining (indicated by the yellow-orange color), and the South Core has more mica (fig. 9). The mica is colorless, which is a notable trait of potassium-rich muscovite and is further evidence for the potentially high gamma-emitting behavior of muscovite at the LAS rather than an effect of clays.

\section{Water-Table Conditions}

Changing patterns in basin use are related to spatially variable water-table responses at the LAS, so representing true static water-table conditions is problematic because pausing wastewater infiltration activity for a period of time for the aquifer to equilibrate is not possible. Water levels at the LAS can vary as much as $19 \mathrm{ft}$, such as in PW-B1 (table 1; appendix 5,6). Seasonal fluctuations of the water table in this area of New Jersey are typically as much as $8 \mathrm{ft}$ (Watt and others, 2002), so higher variations in LAS water levels are likely an effect of the infiltrating wastewater at the site. The regional unconfined flow gradient through the site is toward the southeast (Watt and others, 2002) (fig. 10), except where groundwater discharges to streams that flank the LAS. Two possible explanations regarding water-table related barriers to wastewater infiltration in B5 and B6 were considered - (1) the intersection of the regional water table with topographically low basin surfaces and (2) a perched water table.

\section{Intersection of Water Table with Basins B5 and B6}

A possible explanation for the persistent ponded water on the surfaces of basins B5 and B6 is the intersection of the water table with land surface. For this scenario to be met, certain hydrologic conditions are required. Well PW-B2 is upgradient from PW-B5, and PW-B4 is upgradient from PW-B6, so the water-table altitudes in upgradient PW-B2 and PW-B4 must be higher than the altitudes of downgradient basin bottoms of B5 and B6 for the water table to intersect. Because wastewater effluent is no longer pumped into basins B5 and B6, mounding centered at those basins that could result in downgradient wells with higher water levels than those upgradient will not occur. Water levels in PW-B4 indicate these conditions are not met for the ponded water on the surface of B6 to result from water table intersection. From 2000-15, the highest water level measured in PW-B4 was $107.12 \mathrm{ft}$ on February 27, 2004 (appendix 5) (Optech Monette, LLC., written commun., 2015), an altitude less than the basin B6 altitude of $108 \mathrm{ft}$ (table 1, fig. 11). The measured PW-B6 water level on this date was $101.66 \mathrm{ft}$ (appendix 5), so the groundwater flow gradient was from PW-B4 to PW-B6. Regardless of whether basin $\mathrm{B} 6$ had ponded water at the time of measurement, the water table could not have reached the altitude necessary to intersect with land surface in B6 on that 1-dimensional line (fig. 11). During observed hydrologic conditions in April 2015, ponded water covered the entire surface of B6, except for a small patch around auger boring nest AB-B6-1, where depth to water was $0.15 \mathrm{ft}$ below the basin surface (table 1). Concurrent measured water levels in PW-B4 and PW-B6 indicate a hypothetical water table surface about 7-9 ft below the basin surface, too low for water-table intersection between those points (fig. 11). The low water level of PW-B6 is particularly important to this notion because groundwater was present at a 3.5-ft depth in auger boring AB-B4 at an altitude of $108.5 \mathrm{ft}$, which is almost $6 \mathrm{ft}$ higher than in PW-B4 and $0.5 \mathrm{ft}$ higher than the bottom of basin B6 (table 1). The difference in water levels between AB-B4 and PW-B4 occurred over a large enough distance (about $300 \mathrm{ft}$ ) (fig. 12) to reasonably assume a realistic match for water-table altitude conditions, so flow from basin B4 entering basin B6 and ponding on the surface is plausible. However, the altitude drop of $10 \mathrm{ft}$ over a distance of less than $100 \mathrm{ft}$ between the ponding on basin B6 and the water level in PW-B6 (fig. 11) is an unrealistic match to regional water-table altitude conditions. Therefore, another factor besides the water table is preventing the basin water from infiltrating, and the ponded water remaining on basin B6 following a supposed intersection of the water table is 


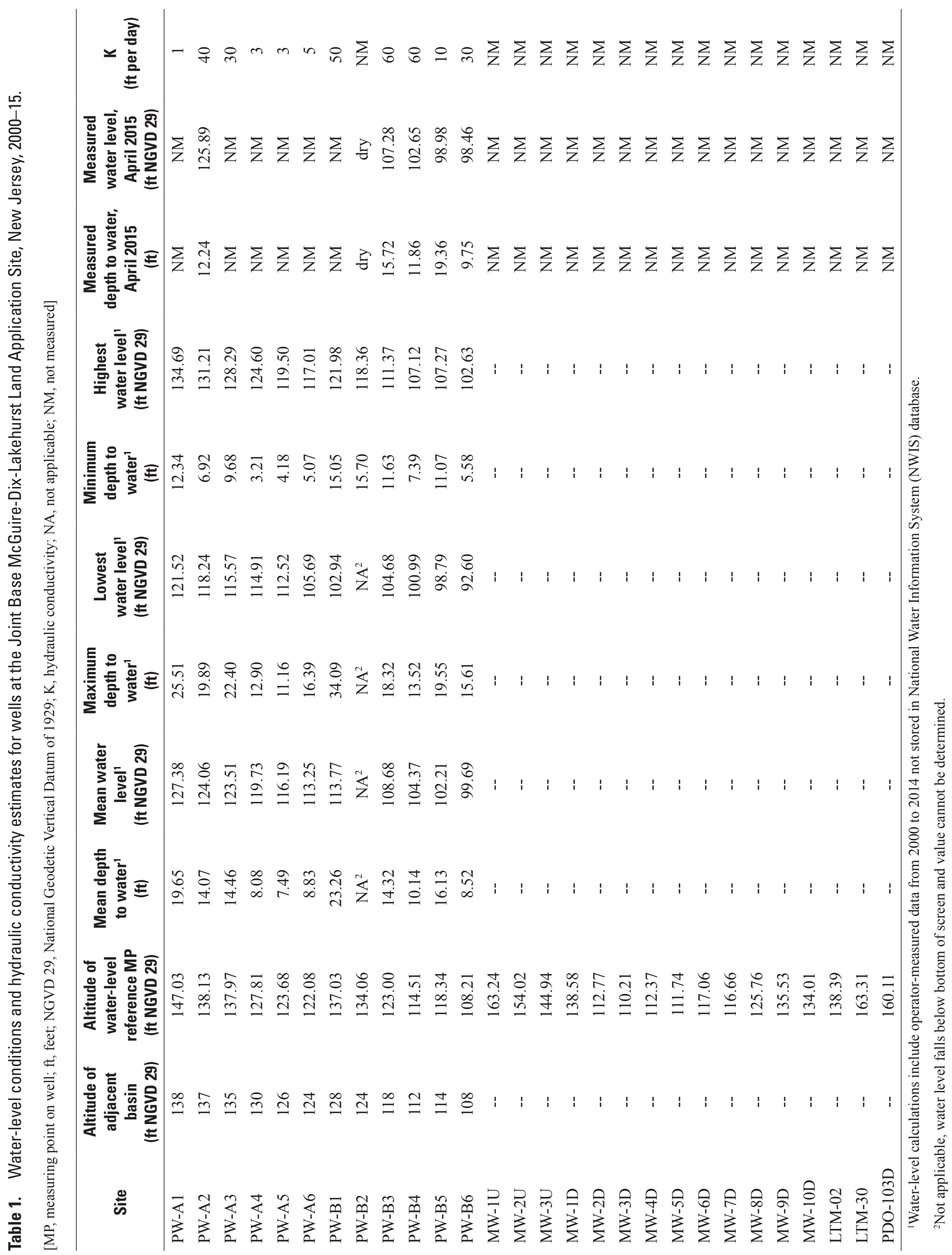


A

FEET

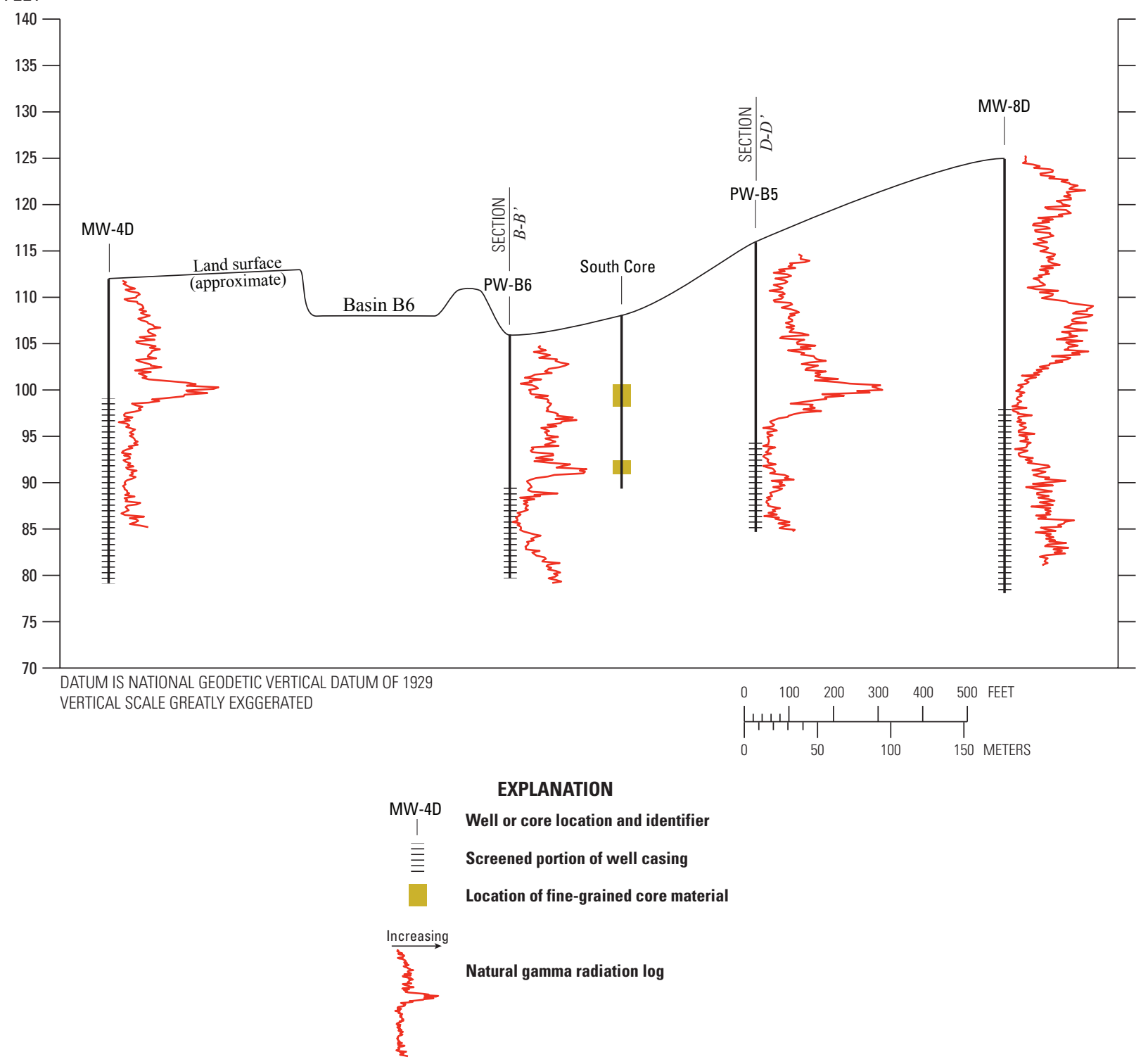

Figure 8. Section $A-A$ 's showing natural gamma logs of MW-4D, PW-B6, PW-B5, and MW-8D, and depths of fine-grained material in the South Core, Joint Base McGuire-Dix-Lakehurst Land Application Site, New Jersey. Gamma radiation increases to the right. 


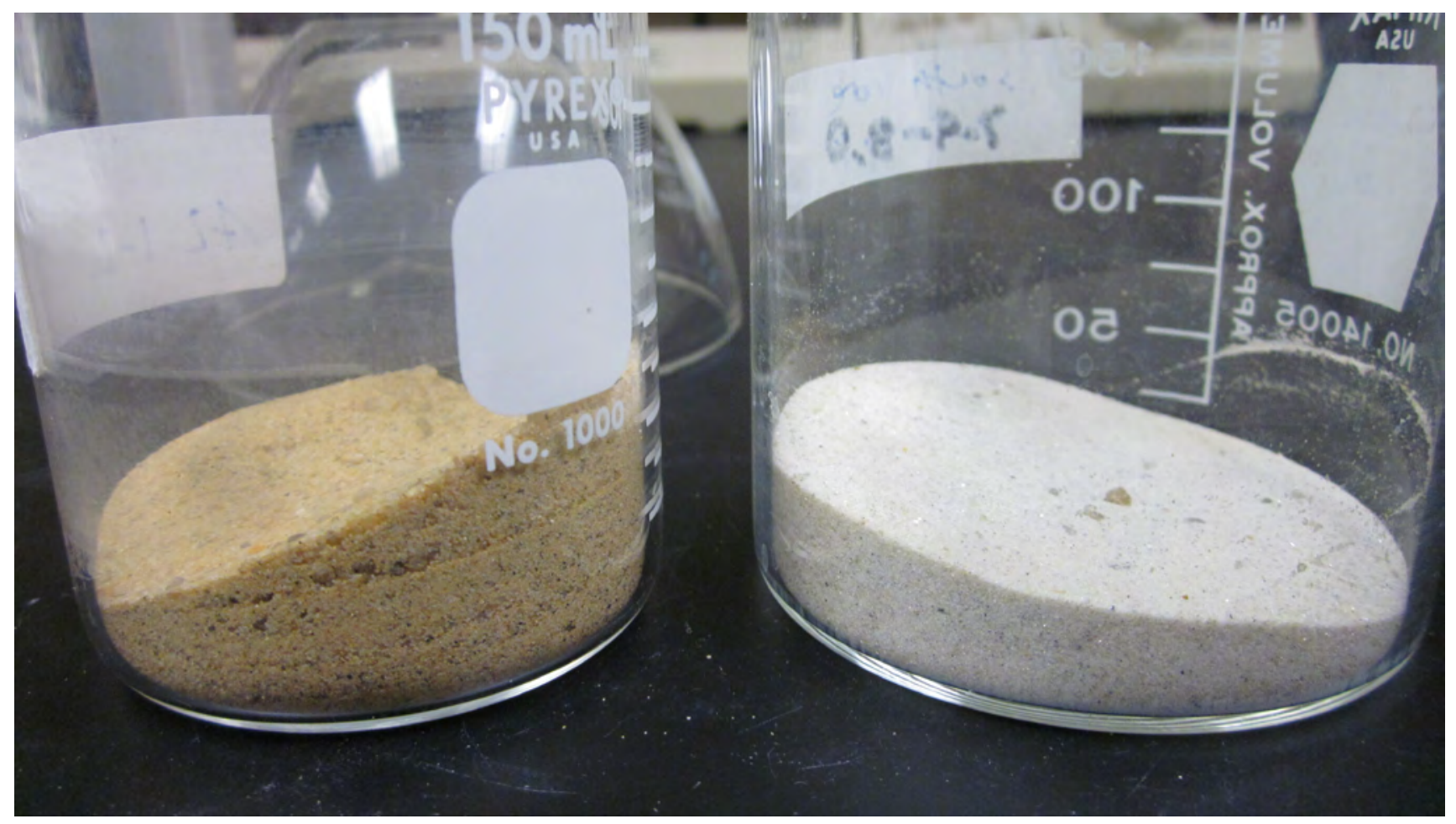

Figure 9. Ferric oxide stained sediment from North Core (left) and muscovite mica-rich quartz sand from South Core (right), Joint Base McGuire-Dix-Lakehurst Land Application Site, New Jersey. 


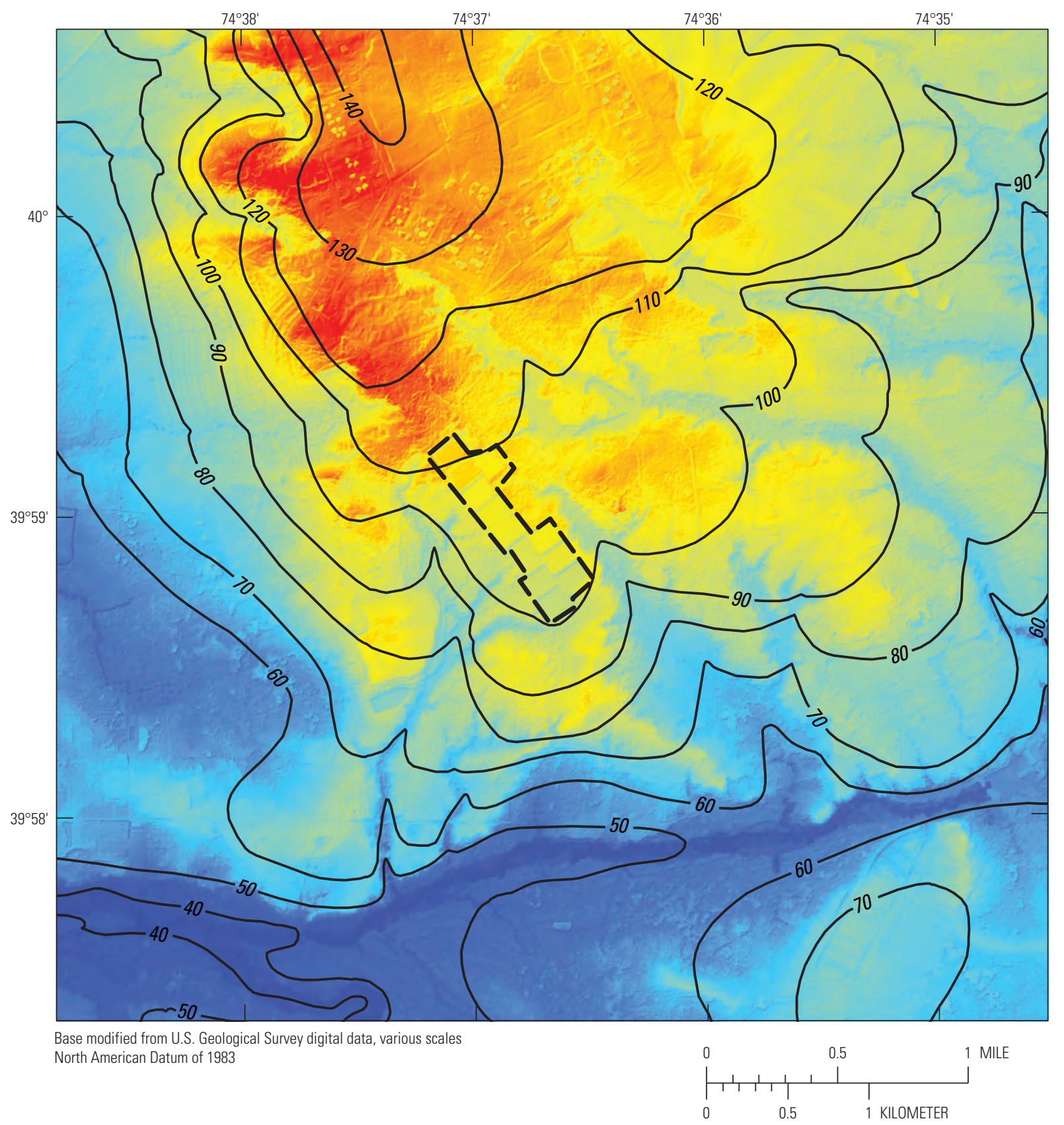

\section{EXPLANATION}

High : 230

LiDAR Digital Elevation Model (New Jersey Office of Information Technology, 2011) Low : 30

Figure 10. Topography and estimated water-table contours in the vicinity of the Joint Base McGuire-Dix-Lakehurst Land Application Site, New Jersey. 

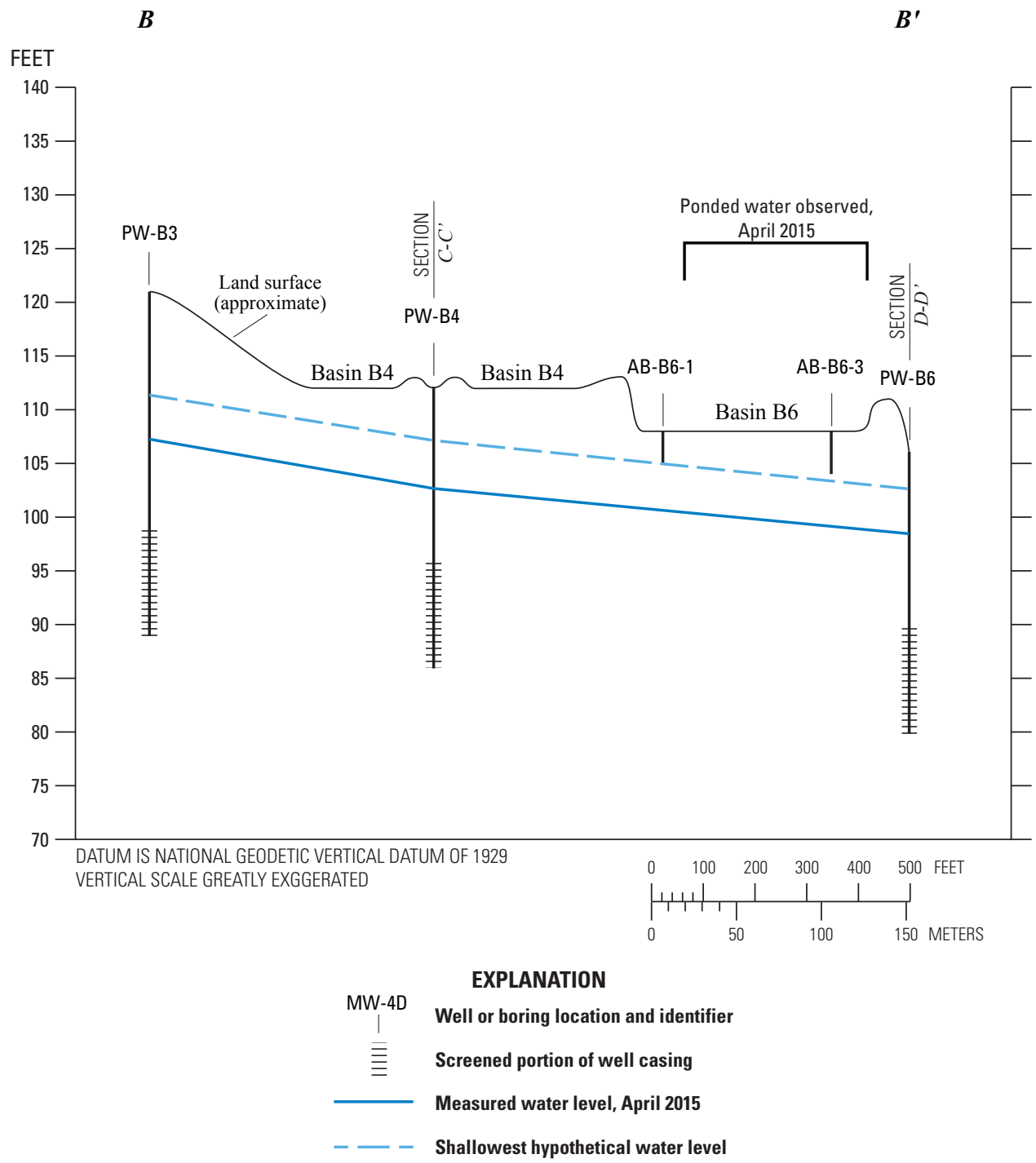

Figure 11. Section $B-B^{\prime}$ showing water levels in relation to infiltration basins $B 4$ and $B 6$, Joint Base McGuire-Dix-Lakehurst Land Application Site, New Jersey. 
$C$

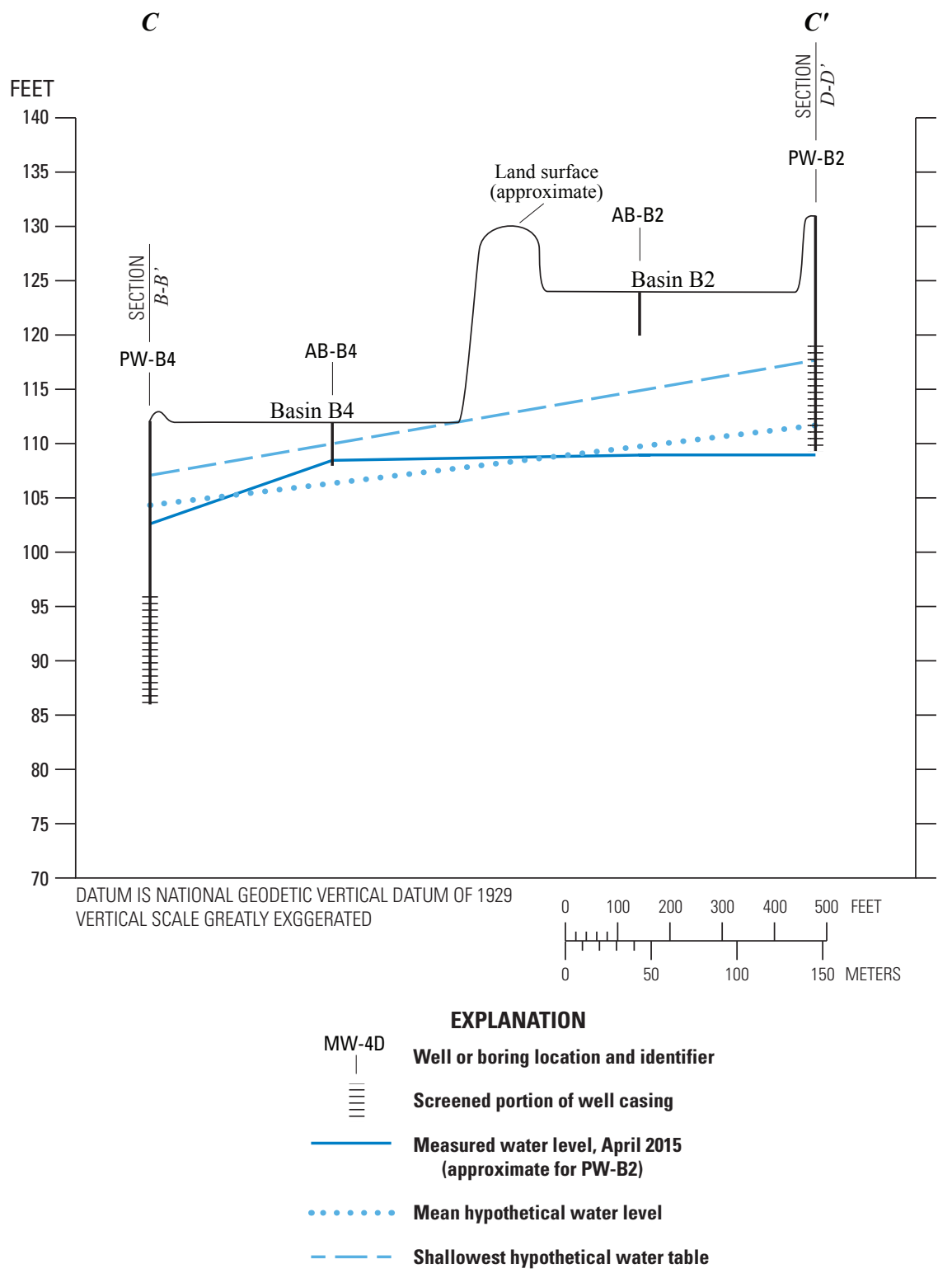

Figure 12. Section $C$ - $C^{\prime}$ showing water levels in relation to infiltration basins $B 2$ and B4, Joint Base McGuire-Dix-Lakehurst Land Application Site, New Jersey. 
Table 2. Grain size analysis results as estimated by use of the wet sieve method through 74-micron mesh, Joint Base McGuireDix-Lakehurst Land Application Site, New Jersey.

[ft BLS, feet below land surface]

\begin{tabular}{lccc}
\hline Site name & $\begin{array}{c}\text { Zone } \\
\text { (ft BLS) }\end{array}$ & $\begin{array}{c}\text { Percent } \\
\text { sand, } \\
\text { by mass }\end{array}$ & $\begin{array}{c}\text { Percent } \\
\text { clay/silt, } \\
\text { by mass }\end{array}$ \\
\hline AB-A2 & $0-1$ & 83 & 17 \\
AB-A2 & $1-2$ & 89 & 11 \\
AB-A2 & $2-3$ & 92 & 8 \\
AB-A2 & $3-4$ & 92 & 8 \\
AB-A2 & $0-1$ & 95 & 5 \\
AB-B2 & $0-1$ & 95 & 5 \\
AB-B2 & $1-2$ & 88 & 12 \\
AB-B2 & $2-3$ & 83 & 17 \\
AB-B2 & $3-4$ & 98 & 2 \\
AB-B3 & $0-1$ & 94 & 6 \\
AB-B3 & $1-2$ & 95 & 5 \\
AB-B3 & $2-3$ & 90 & 10 \\
AB-B4 & $0-1$ & 94 & 6 \\
AB-B4 & $1-2$ & 89 & 11 \\
AB-B4 & $2-3$ & 76 & 24 \\
AB-B4 & $3-4$ & 96 & 4 \\
AB-B5-1 & $0-1$ & 84 & 16 \\
AB-B5-1 & $1-2$ & 74 & 26 \\
AB-B5-1 & $2-3$ & 76 & 24 \\
AB-B5-1 & $3-4$ & 77 & 23 \\
AB-B5-2 & $0-1$ & 77 & 23 \\
AB-B5-2 & $1-2$ & 90 & 10 \\
AB-B5-2 & $2-3$ & 86 & 14 \\
AB-B5-2 & $3-4$ & 91 & 9 \\
AB-B6-1 & $0-1$ & 85 & 15 \\
AB-B6-1 & $1-2$ & 83 & 17 \\
AB-B6-1 & $2-3$ & 56 \\
AB-B6-1 & Isolated finer subsample & 58 & 14 \\
South core & $7.9-1$ & 85 \\
South core & 15.8 & \\
\hline & & 95 \\
\hline
\end{tabular}

restricted by another factor. The possibility of a perched water table at that location acting as that factor is discussed in the section "Test for Perched Water Table."

Numerous water levels in PW-B2 recorded between 2000 and 2015 were at high enough altitudes to potentially intersect basin B5 (table 1; appendix 5). However, basin B5 had ponded water in April 2015 when PW-B2 was dry. The water table at PW-B2 must fall below the bottom of the screen for the well to be dry, and the bottom of PW-B2 is at a lower altitude than the bottom of basin B5, so a hypothetical water table would fall at least $8 \mathrm{ft}$ below the basin surface, depending on how far the water table is below the screen (fig. 13). A seepage face present on the berm separating B5 and B2 (fig. 14) indicates flow occurs through the dividing berm into B5 when B2 is holding water, which is evidenced further by high moisture content observed on the B5 side when B2 was in use on a later date. The top of the seepage face on the slope on the B5 side correlates approximately with the altitude of the bottom of basin B2 on the opposite side. When wastewater effluent is infiltrating, not all flow is downward; there is a lateral component through the berms allowing water to flow from one basin to another. Water can flow into B5 from B2 during this process, but as in B6, the assumed gradient between B5 ponded water and the water level in PW-B5 would be very large, and another factor must be present that prevents infiltration. Flow across berms also may provide a source of ponded water in B5 and B6. Because effluent is not directly discharged to B5 and B6, ponded water in those basins must originate elsewhere. The source is likely some combination of cross-berm flow, precipitation directly into the basins, and runoff down berm slopes. Because B2 is frequently in use (Optech Monette, LLC., written commun., 2014), a portion of the effluent from B2 will concurrently flow through the berm into B5. B2 effluent may also surface in B6, if it is passing through B4.

In general, differences in altitude between basin surfaces and mean water levels in associated adjacent piezometers are smaller in the topographically lower basins, especially in basin B4 and site PW-B4 (table 1). A shallower water table and shorter unsaturated zone would slow down the infiltration of wastewater, but that is not enough to explain persistent ponded water on B5 and B6. The relatively poor, but not completely ineffective wastewater infiltration capabilities of basins B3 and B4 are more likely caused by a shallow water table (table 1). As stated previously, the shallow water table at AB-B4 in April 2015 matches the regional conditions, and a higher gradient from basin B2 can potentially cause the water table below B4 to be even shallower (fig. 12). This also applies to basin $\mathrm{B} 3$ because groundwater was reached at a depth of about $2 \mathrm{ft}$ in auger boring $\mathrm{AB}-\mathrm{B} 3$ in basin $\mathrm{B} 3$ in April 2015 (table 3). Nearby basins A5, A6, and B1 were in operation infiltrating wastewater in April 2015 when these measurements were made. Local groundwater mounding below A5, A6, and B1 likely raised the water level in boring $\mathrm{AB}-\mathrm{B} 3$ to a gradient more than $8 \mathrm{ft}$ higher than in well PW-B3 (table 1), unless a low permeability layer went undetected at 


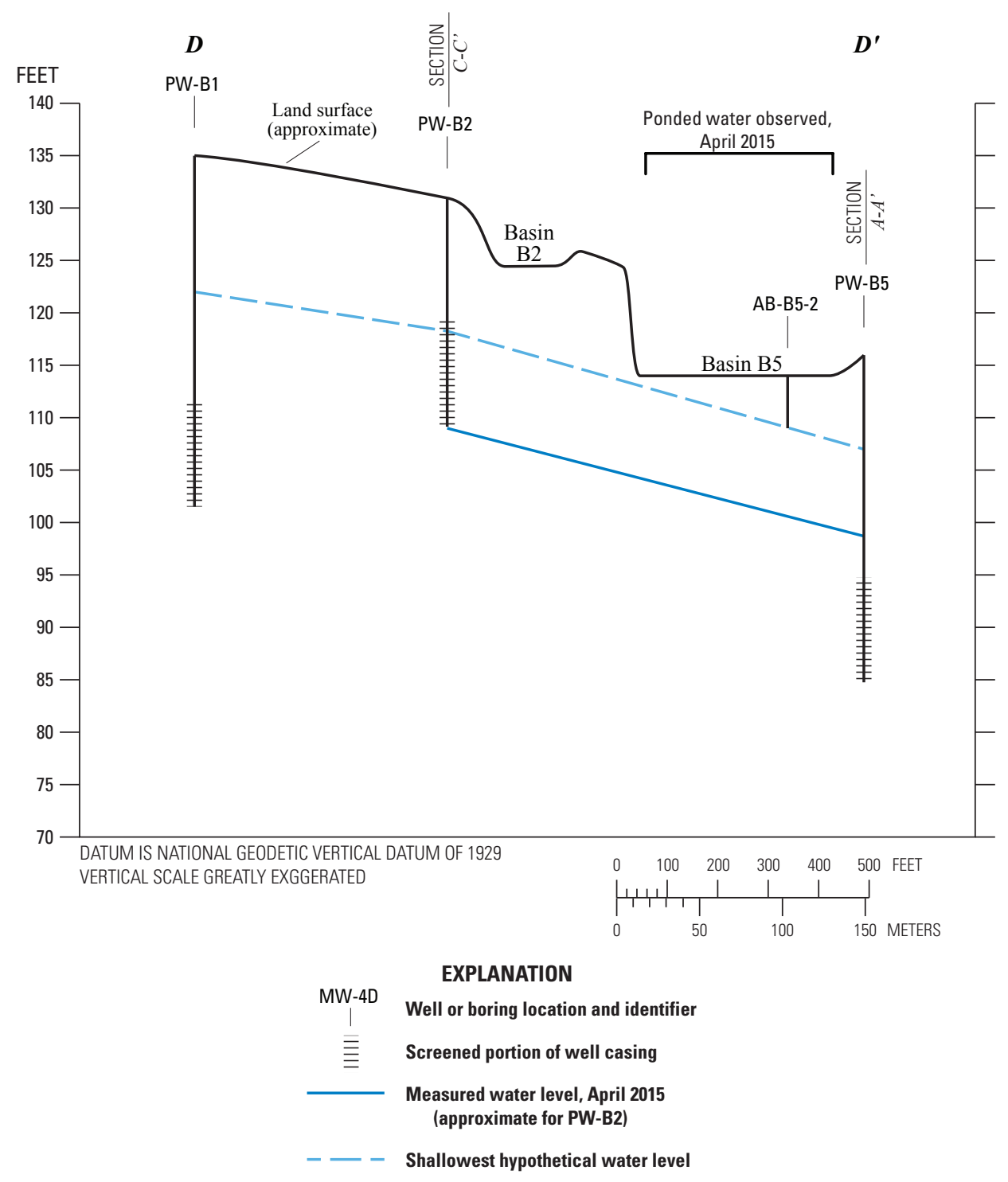

Figure 13. Section $D-D^{\prime}$ showing water levels in relation to infiltration basins B2 and B5, Joint Base McGuire-Dix-Lakehurst Land Application Site, New Jersey. 


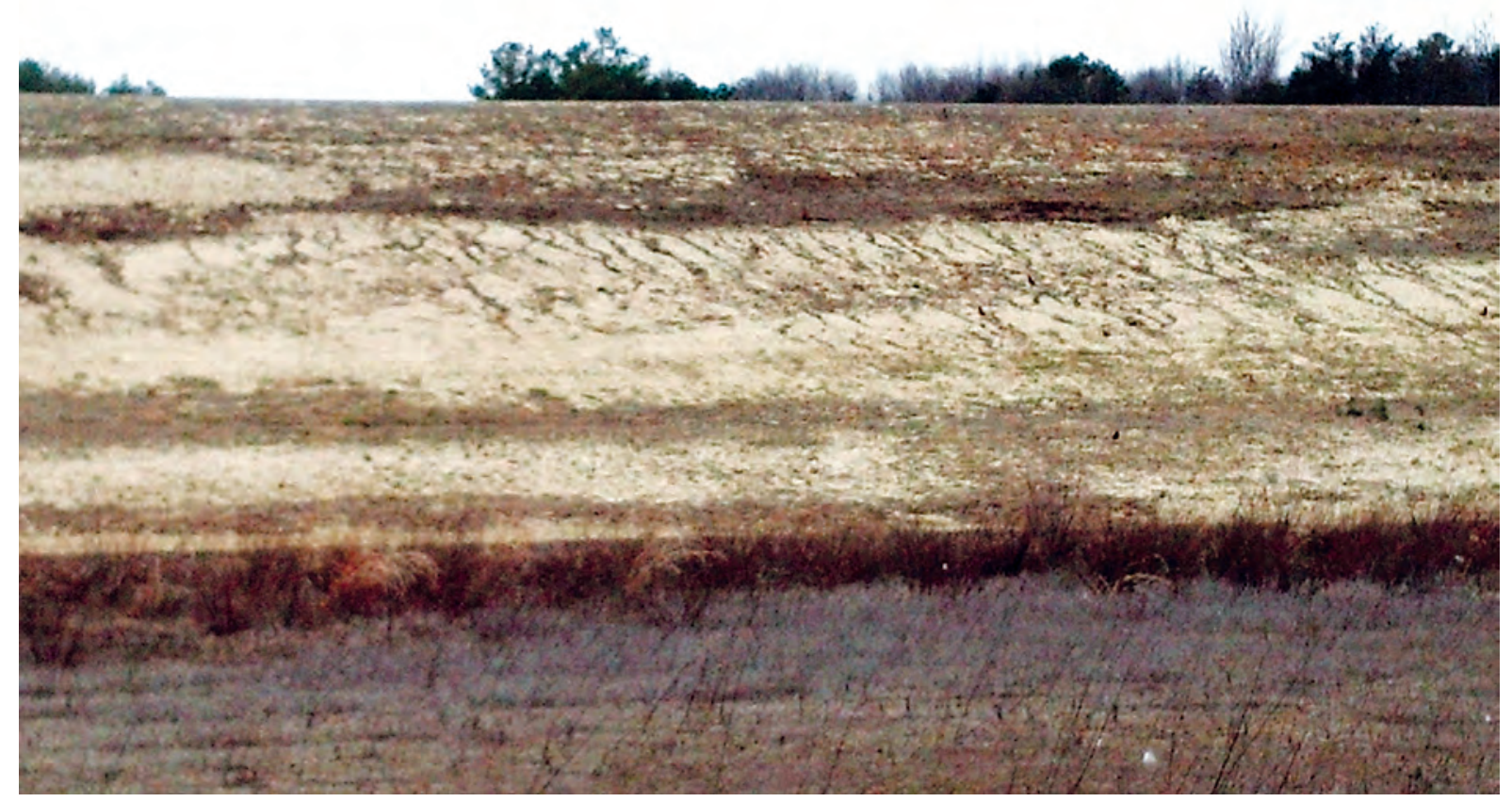

Figure 14. Seepage face flow structures on the berm between basin B5 and basin B2, Joint Base McGuire-DixLakehurst Land Application Site, New Jersey. Flow structures originate about 10 feet above the bottom of basin B5 at the approximate altitude of basin B2 on the opposing side.

Table 3. Description of auger boring test holes and depth to water measurements, Joint Base McGuire-Dix-Lakehurst Land Application Site, New Jersey, April 2015

[USGS ID, U.S. Geological Survey station number; NJUID, New Jersey unique identifier; BLS, below land surface; ALS, above land surface]

\begin{tabular}{lcccc}
\hline \multicolumn{1}{c}{ Site } & USGS ID & NJUID & $\begin{array}{c}\text { Depth of } \\
\text { hole, in } \\
\text { feet BLS }\end{array}$ & $\begin{array}{c}\text { Depth to } \\
\text { water, in } \\
\text { feet BLS }\end{array}$ \\
\hline AB-A2 & 395909074370201 & 051973 & 4 & Dry \\
AB-B2 & 395852074363901 & 051972 & 4 & Dry \\
AB-B3 & 395851074364601 & 051971 & 4 & 2 \\
AB-B4 & 395846074364201 & 051970 & 4 & 3.5 \\
AB-B5-1A & 395846074363601 & 051966 & 3 & 0.9 \\
AB-B5-1B & 395846074363602 & 051967 & 2 & 0.3 \\
AB-B5-1C & 395846074363603 & 051968 & 1 & 0.3 \\
AB-B5-2 & 395846074363301 & 051969 & 5 & Dry \\
AB-B6-1A & 395844074364101 & 051963 & 3 & 0.8 \\
AB-B6-1B & 395844074364102 & 051964 & 2 & 0.15 \\
AB-B6-1C & 395844074364103 & 051965 & 1 & 0.15 \\
AB-B6-2 & 395844074363801 & 051962 & 3 & ALS \\
AB-B6-3 & 395842074363801 & 051960 & 2 & ALS \\
AB-B6-4 & 395842074364101 & 051961 & 5 & ALS \\
\hline
\end{tabular}


depths between the bottom of AB-B3 and screen of PW-B3. Therefore, although regional water-table intersection with B5 and B6 is not impossible, it does not appear to be the primary cause of the persistent ponded water, and the ponded water is not a surficial expression of the water table intersecting with land surface.

\section{Test for Perched Water Table}

The high percentages of sand and apparent lack of clays in the South Core and North Core are unlikely to support a perched water table, but the possible existence of a perched water table, as demonstrated in the previous section, requires testing. A temporary nested borehole was hand augered $2 \mathrm{ft}$ from PW-B6 to test for a perched water table at that location. The water level in PW-B6 at the time of the test was measured to be about $8 \mathrm{ft}$ below land surface, and groundwater was first encountered in the auger hole at $8 \mathrm{ft}$ below land surface. Basin B6 had ponded water at the time. If a perched water table was present, groundwater would have been reached at depths shallower than $8 \mathrm{ft}$ in the auger boring, but equal water levels indicate the sediments surrounding the screen of well PW-B6 and those in the upper $8 \mathrm{ft}$ of the test boring are hydraulically connected and both unconfined. The GPR profile traversing PW-B6 provides supplementary evidence that no perched water table is present (fig. 15). At the time of the GPR survey, the water level in PW-B6 was measured to be $7.43 \mathrm{ft}$ below land surface. A large reflection at 25 nanoseconds (ns) (fig. 15; appendix 1, line 10) can be calibrated to $7.43 \mathrm{ft}$ assuming a ground velocity of about $594 \mathrm{ft} /$ microsecond, which is within the expected velocity range for unsaturated sands (Pierre Lacombe, USGS, oral commun., 2015). This reflection extends laterally throughout the profile and is likely caused by the water table, further confirming the absence of perched water near basin B6. Perched water was not tested at well PW-B5 because hand augering is unwieldy considering the greater depth to water at that location. However, no obvious water-table reflection is noticeable on the GPR line 10

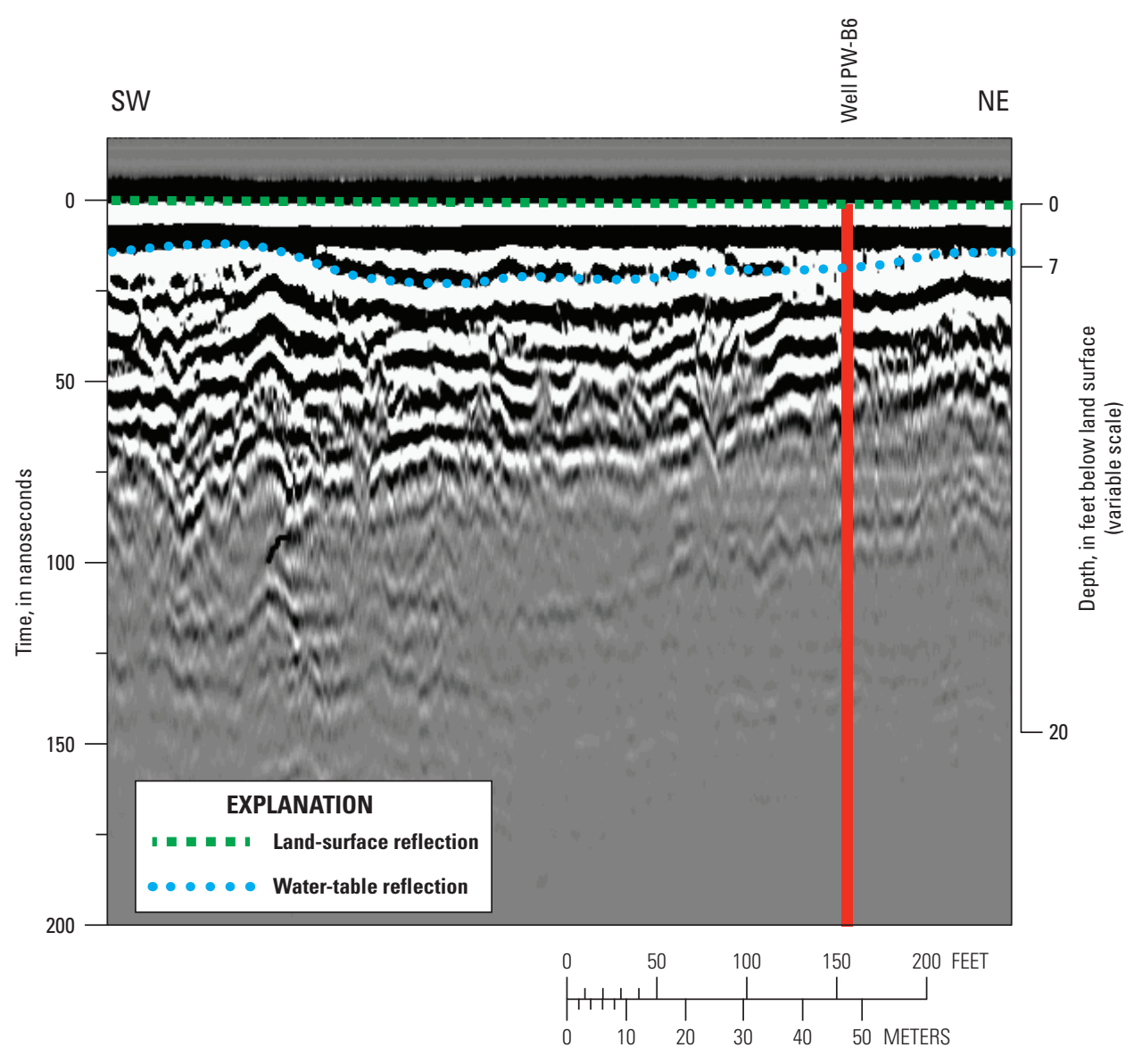

Figure 15. Segment of ground-penetrating radar line 10 with interpreted reflections, Joint Base McGuire-Dix-Lakehurst Land Application Site, New Jersey. A direct current (DC) removal filter with start sample 660 was applied to all ground-penetrating radar data for calculation of DC level. Assumed ground velocity 515 feet per microsecond (ft/ $\mu \mathrm{s}$ ) above water table, $200 \mathrm{ft} / \mu \mathrm{s}$ below water table. Well diameter not to scale. 
near well PW-B5 (appendix 1), which indirectly indicates the absence of perched water table at that location. Assuming the same ground velocity at PW-B5 as calibrated with PW-B6 and using the same filter settings, the GPR signal extinguishes at about $19 \mathrm{ft}$, just before it reaches the water-table depth as measured in PW-B5. The signal reaches nearly $100 \mathrm{~ns}$, which is almost double the travel time of that near PW-B6. The signal is probably attenuated through time by lithology rather than a strong reflection, such as the water table in PW-B6, which indicates a perched water table likely is not present at PW-B5.

\section{Shallow Heterogeneity of Infiltration Basins}

Sediments recovered in auger borings through the first 3-5 $\mathrm{ft}$ below the bottoms of basins were consistently at least $74 \%$ sand (table 2). The sediments of the untested basins A1, A3, A4, A5, A6, and B1 are likely of similar composition. The only outlier is a shallow clay layer observed in auger borings within basins B3, B4, B5, and B6 that may provide the best explanation for the ineffective infiltration in B5 and B6.

Boring AB-B6-1A was augered in a small patch of relatively dry sediment in B6 when most of the basin had ponded water on the surface. Sediments in the first $2 \mathrm{ft} \mathrm{BLS}$ were mostly sand of similar texture to that encountered in auger holes of other basins, except for a thin layer of decaying plant material and organics at the surface that likely accumulated after the sustained exclusion of B6 from site operations since the 1990s. Saturation developed a few inches below the basin surface. Approximately $2 \mathrm{ft}$ BLS was a dense, highly pliable clay and sand mixture overlying loose dry sand about $2.5 \mathrm{ft}$ BLS. The clay layer at $2 \mathrm{ft}$ BLS was estimated to be about $42 \%$ clay/silt and $58 \%$ sand from the sieve analysis and would be classified as a "sandy clay" or "sandy clay loam" on the basis of National Resource Conservation Service soil texture parameters (Schoeneberger and others, 2012). The clay percentage might be underestimated if any clay was inadvertently washed out of the auger bucket during sampling. The auger hole was terminated at $3 \mathrm{ft}$ BLS because of repeated collapse. Nested 1-ft (AB-B6-1C) and 2-ft (AB-B6-1B) deep auger borings were installed with $\mathrm{AB}-\mathrm{B} 6-1 \mathrm{~A}$ above the clay layer at $2 \mathrm{ft}$ BLS to test the hydraulic nature of the clay layer. Stabilized water levels in the 1-ft and 2-ft borings were equal, about $0.15 \mathrm{ft} \mathrm{BLS}$ (table 3). The stabilized water level in the 3 -ft boring was deeper, about $0.8 \mathrm{ft}$ BLS (table 3 ). Differential level surveys of each boring in the nest put the true vertical elevations within $0.03 \mathrm{ft}$ of each other, so the 0.65 - $\mathrm{ft}$ lower water level in the $3-\mathrm{ft}$ boring was not caused by topographic deviations of land surface. Removal of clay during augering likely formed a conduit between the saturated and unsaturated material, and the lower water level in the 3 - $\mathrm{ft}$ boring represents the slow leakage of groundwater into the deeper sand after removal and disturbance of the clay. Therefore, the clay acts as a low permeability barrier preventing the downward flow of water from the overlying saturated sand into the underlying unsaturated sand.
This low permeability clay was also present near the southwest corner of basin B5 in auger boring AB-B5-1A at about $2 \mathrm{ft}$ BLS with saturation above and unsaturation below around $2.75 \mathrm{ft}$ BLS. A nest of auger borings installed with AB-B5-1A had stabilized water levels similar to those of the AB-B6-1 nest. Water levels in 1-ft (AB-B5-1C) and 2-ft (AB-B5-1B) deep nested borings were both about $0.3 \mathrm{ft}$ BLS, whereas the water-level depth in the 3-ft deep AB-B5-1A was $0.9 \mathrm{ft}$ BLS (table 3). Differential level surveys were not completed in this nest, but based on the results in basin B6, the water-level decline in the 3-ft auger boring likely resulted from the removal of low permeability clay rather than topographic deviation. Auger boring AB-B5-2 was installed farther away from ponded water than AB-B5-1 and did not contain any clay or groundwater through $5 \mathrm{ft} \mathrm{BLS}$ (table 2) during these conditions.

Observations from additional auger borings further indicate lithologic heterogeneity within the basins. Auger borings AB-B6-2, AB-B6-3, and AB-B6-4, installed in basin B6 (fig. 1) on a later date when the land surface was dry, contained clay at about $2 \mathrm{ft}$ BLS but with varying thicknesses. The clay encountered in boring AB-B6-2 was at least $1.5 \mathrm{ft}$ thick, which is the thickest of all locations where it was observed. In boring AB-B6-3, the clay was at least $1 \mathrm{ft}$ thick. Saturated sand above the clay in AB-B6-2 and AB-B6-3 kept collapsing the hole, so the bottom of the clay and potentially dry sand beneath were never reached as in AB-B5-1A and AB-B6-1A. The clay encountered in AB-B6-4 was about $0.5 \mathrm{ft}$ thick, and no groundwater was encountered through $5 \mathrm{ft}$. The absence of groundwater in AB-B6-4 may result from the thinner clay that allowed water to penetrate or a slightly higher sand content with greater permeability, rather than an absence of groundwater causing clay shrinkage because of specific mineralogy with high shrink/swell capabilities.

The absence of clay in AB-B5-2 indicates the clay in basin $\mathrm{B} 5$ pinches out at some location between AB-B5-1 and AB-B5-2, which may be observable on GPR line 33 (fig. 16; appendix 1). At the time line 33 was surveyed, very wet conditions were present near the surface on the western side of basin B5 where the clay was observed. These wet conditions extended to a distance of approximately $165 \mathrm{ft}$ on line 33 and likely caused the obscured and distorted appearance of the underlying reflections across this interval (fig. 16). The interpreted water-table reflection is better defined when these conditions subside. PW-B5 and AB-B5-2 are approximately normal to the $260-\mathrm{ft}$ distance on line 33 where clay and groundwater were not observed during the spring high water-level season. Many ground velocities through unsaturated sand can be safely applied to line 33 that would put the $25 \mathrm{~ns}$ water-table reflection at more than $5 \mathrm{ft}$ BLS, indicating the water table at $260 \mathrm{ft}$ distance could potentially be deeper than the ponded water to the west. The wet conditions to the west are perched on top of the clay found in nest AB-B5-1, and the decline of these conditions at $165 \mathrm{ft}$ may correspond to a pinch-out of the clay at this distance. High signal attenuation in an area with ponded water in line 31 (about 220-375 ft) and 


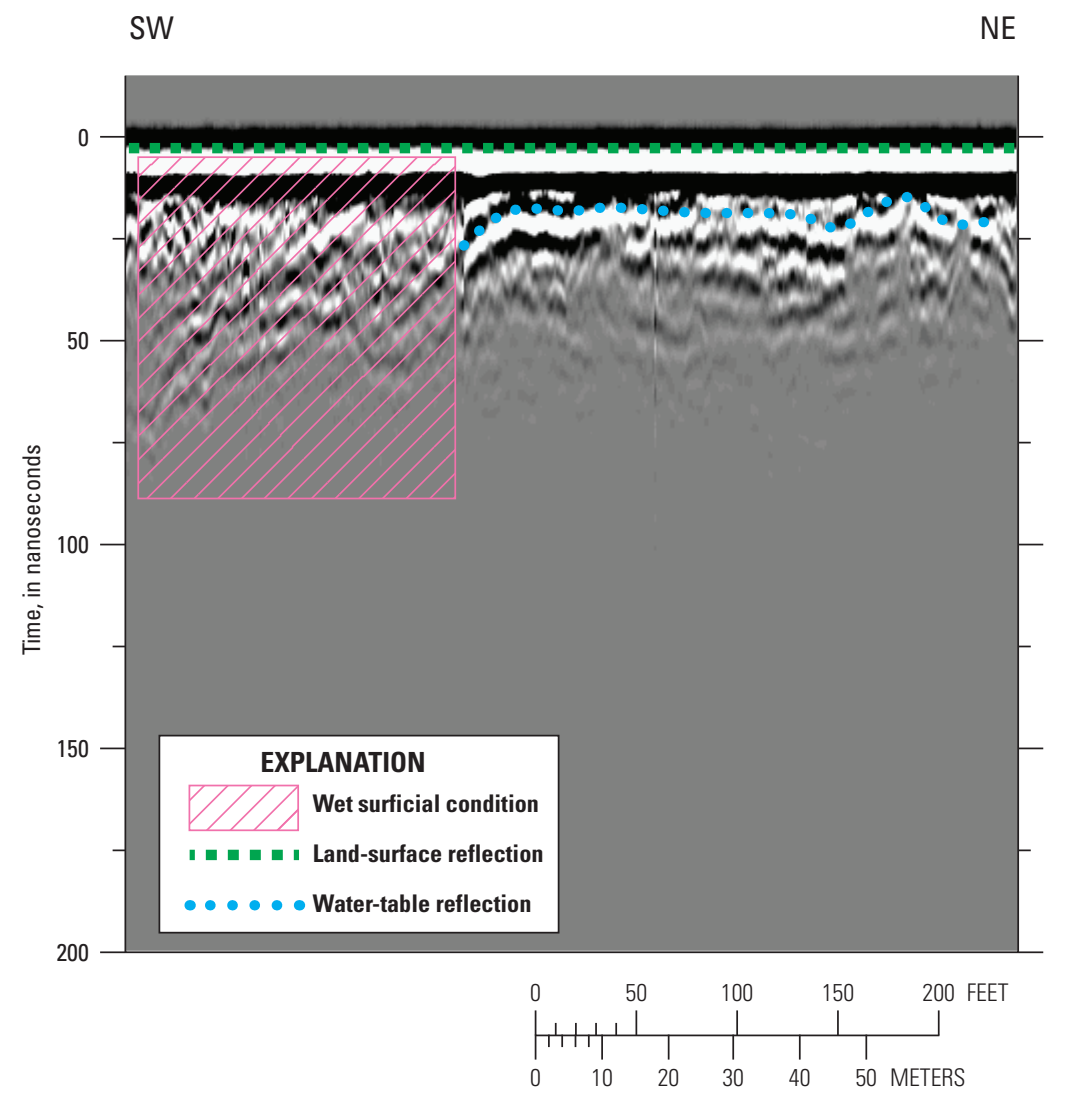

Figure 16. Ground-penetrating radar line 33 in basin B5 with interpreted water table reflection, Joint Base McGuire-Dix-Lakehurst Land Application Site, New Jersey. A direct current (DC) removal filter with start sample 660 was applied to all ground-penetrating radar data for calculation of DC level. No assumed ground velocity due to lack of calibration targets. Contrast between positive and negative peaks reduced for better visual clarity.

line 32 (390-470 ft) indicates clay extent may also reach to the northeastern corner of B5 (appendix 1).

Thin layers (less than $0.5 \mathrm{ft}$ thick) resembling the clay below basins $\mathrm{B} 5$ and $\mathrm{B} 6$ were also present in borings AB-B3 and AB-B4 at depths of $2.5 \mathrm{ft}$ and $3.75 \mathrm{ft}$ BLS, respectively, with saturation of both overlying and underlying sands, which indicates low shrink/swell capability and infiltration of water through these thinner zones. Samples of this material from $\mathrm{B} 3$ and B4 were too thin to be isolated for sieve analysis, so the texture of this unit compared to seemingly similar restrictive units observed in B5 and B6 could not be quantitatively evaluated for a potentially higher sand content. The interpreted water table is a very strong reflection on GPR line 15 that around $250 \mathrm{ft}$ begins to appear at increasingly later times as a shallower reflector appears above (fig. 17). Later reflection times do not necessarily correspond to deeper depths, but instead longer travel times resulting from attenuated velocities of the emitted pulse with a change of electromagnetic properties of subsurface materials above the reflector interface. The shallower reflection in line 15 may be caused by a bedding pinch-out of the AB-B3 "clay." This bedding reflection occurs progressively earlier in time as the water-table reflection occurs progressively later, which may result from the bed thickening toward the southeast and causing the underlying water-table reflection to appear increasingly later in time. At about $450 \mathrm{ft}$, signal penetration decreases and both reflectors are obscured (fig. 17) from greater attenuation at the basin surface. Relatively wetter conditions were present near the southeast corner of basin B3 at the time line 15 was surveyed, which likely enhanced the attenuation. Although AB-B3 results do not indicate perching of water, the bed in line 15 may thicken enough to slow infiltration and cause these wetter conditions near the southeast corner, which is likely given the heterogeneity present in basins B5 and B6. Line 16 surveyed in basin B4 is of limited utility because of noise and ghost reflections, so the nature of the clay in B4 is not evident from its GPR line.

The origin of this clay layer observed in these basins is unknown, as is whether the clay at each location forms one feature or multiple independent beds. Sediments underlying 


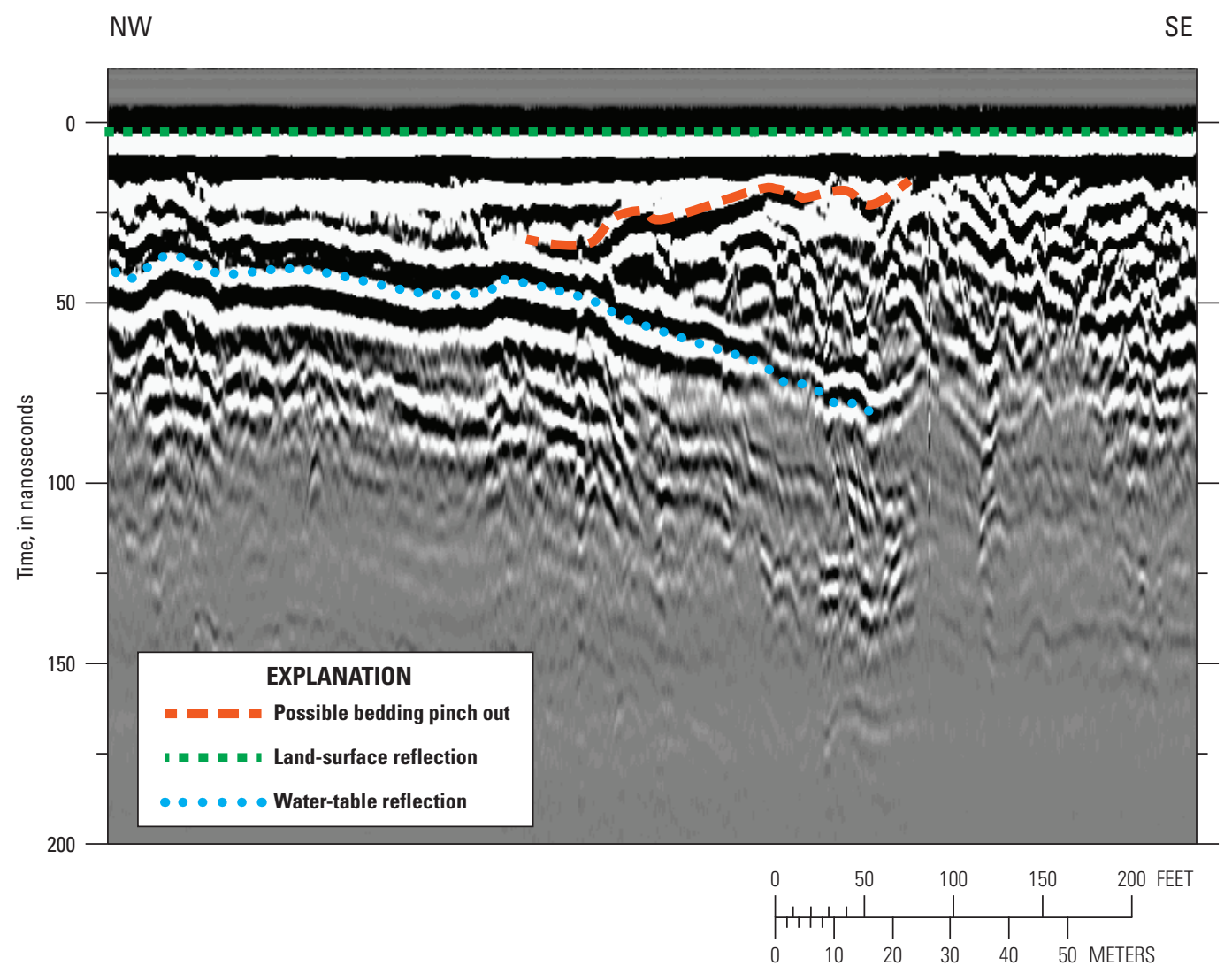

Figure 17. Ground-penetrating radar line 15 in basin B3 with interpreted reflections, Joint Base McGuire-Dix-Lakehurst Land Application Site, New Jersey. A direct current (DC) removal filter with start sample 660 was applied to all ground-penetrating radar data for calculation of DC level. No assumed ground velocity due to lack of calibration targets.

infiltration basins are likely unrepresentative of native material (even if originating from native formations) as a result of soil reworking to an unknown depth during site construction and maintenance, including possible geochemical alteration by the differing water quality of infiltrating wastewater compared to native groundwater. The sampled clay was about $2-4 \mathrm{ft}$ below each basin where encountered, but this is hardly informative as to its origins because a native Cohansey Formation clay lens could have been terraced during construction, or given that these basins are topographically lowest at the LAS, fines washed downhill from runoff during basin construction could have built up before subsequent tillage and other reworking of shallower sediments. However, the origins of this clay are not particularly or directly important operationally for the site; the clay is an obstruction for infiltration regardless of its origin. If the upper 3-4 ft of sediment in basins B5 and B6 were excavated and replaced with sand to maintain proper depth to the seasonal high water table below basin bottoms in accordance with Pinelands Comprehensive Management Plan standards (New Jersey Pinelands Commission, 2014), basins B5 and B6 could potentially be useful for the infiltration of wastewater effluent. However, a relatively shallow water table beneath B5 and B6 would lead the basins to perform similarly to slowdraining basins $\mathrm{B} 3$ and $\mathrm{B} 4$.

\section{Summary and Conclusions}

The Land Application Site (LAS) of Joint Base McGuireDix-Lakehurst, Burlington County, New Jersey, was constructed in the 1990s to pump treated wastewater effluent to infiltration basins for recharge into groundwater in the underlying Kirkwood-Cohansey aquifer system. Of the 12 basins constructed at the LAS designed for infiltration, basins B5 and B6 exhibited ineffective infiltration capabilities soon after construction and are no longer used in site operations because of persistent ponded water. The cause of poor infiltration in basins B5 and B6 was never definitively identified, and an understanding of the factors directly affecting the infiltration capacity of the LAS is essential when considering any future 
site plans. The U.S. Geological Survey (USGS) conducted an investigation, in cooperation with the Department of Defense, into the possible hydrogeologic conditions at the LAS that may hinder infiltration at basins B5 and B6. Natural gamma radiation logging in boreholes, ground-penetrating radar (GPR), slug tests of piezometer wells, textural analysis of sediment samples from cores, and water-level data from piezometer wells and auger borings were used in the investigation. Various hypotheses were examined that would potentially cause ineffective infiltration, including the presence of largescale or small-scale low permeability clay units, a perched water table, and the intersection of the regional water table with the B5 and B6 basin surfaces.

Borehole gamma logs were generally inconclusive because the signal was obscured by bentonite grout behind the well casings. High gamma counts from the screened interval indicate possible zones of relatively lower permeability but more likely result from high muscovite mica contents because hydraulic conductivities calculated from slug tests of these zones are more typical of sand than clay. Clay zones were not present in the North Core and South Core. The finestgrained unit in the South Core consisted primarily of very fine sand situated within medium and coarser sands. Piezometer well PW-B6 near the South Core had a water level equal to the shallower nested auger boring adjacently installed. An interpreted water-table reflection on the GPR image occurs around the same depth around the well as the measured water level in the well, which indicates the fine-grained units in the South Core are not impermeable and do not create a perched water table.

A hypothetical water table assumed from water-level measurements indicates the water table is shallower in the southern basins of the LAS where infiltration is less effective than the northern basins. Conditions exist whereby the water table height is sufficient for intersection with basin B6. However, given the lack of water perching at PW-B6, the low water levels measured in PW-B6 indicate that any water on the surface of B6 derived from water-table intersection remains ponded owing to a different cause than water table intersection. Samples of sediment from basins B5 and B6 contained a thin layer of clay that would inhibit infiltration. Sand above this clay was saturated, whereas the sand below the clay was unsaturated. Removal of this clay in auger borings in B5 and B6 formed a conduit that caused the water level in the shallow saturated sands to drop in nested borings. Therefore, this clay is likely preventing water from entering the underlying sand. This phenomenon was not encountered in the basins with effective infiltration, so the presence of this clay is the probable cause of ponded water on the surface of $\mathrm{B} 5$ and $\mathrm{B} 6$ that fails to infiltrate.

\section{References Cited}

ASTM, 2007, Active Standard ASTM D422, Standard Test Method for Particle-Size Analysis of Soils: West Conshohocken, Pa., ASTM International.

Beres, Milan, Jr., and Haeni, F.P., 1991, Application of ground-penetrating radar methods in hydrogeologic studies: Ground Water, v. 29, no. 3, p. 375-386.

Bouwer, Herman, and Rice, R.C., 1976, A slug test method for determining hydraulic conductivity of unconfined aquifers with completely or partially penetrating wells: Water Resources Research, v. 12, no. 3, p. 423-428.

Butler, J.J., Jr., 2002, A simple correction for slug tests in small-diameter wells: Ground Water, v. 40, no. 2, p. 303-307.

Cunningham, W.L., and Schalk, C.W., 2011, Groundwater technical procedures of the U.S. Geological Survey: U.S. Geological Survey Techniques and Methods 1-A1, 151 p.

Fiore, A.R., 2014, Transmissivity and storage coefficient estimates from slug tests, Naval Air Warfare Center, West Trenton, New Jersey: U.S. Geological Survey Open-File Report 2014-1020, 12 p.

Halford, K.J., and Kuniansky, E.L., 2002, Documentation of spreadsheets for the analysis of aquifer-test and slug-test data: U.S. Geological Survey Open-File Report 02-197, $51 \mathrm{p}$.

Keys, W.S., 1990, Borehole geophysics applied to groundwater investigations: U.S. Geological Survey Techniques of Water-Resources Investigation, book 2, chap. E-2, 150 p.

Minard, J.P., and Owens, J.P., 1963, Pre-Quaternary geology of the Browns Mills quadrangle, New Jersey: U.S. Geological Survey Geologic Quadrangle Map GQ-264, scale $1: 24,000$.

New Jersey Office of Information Technology, Office of Geographic Information Systems , 2008, 2007-2008 High Resolution Orthophotography 5000 foot Tile Index: Trenton, N.J.

New Jersey Pinelands Commission, 2014, Pinelands Comprehensive Management Plan, 272 p., accessed March 4, 2015 , at http://www.state.nj.us/pinelands/.

Newell, W.L., Powars, D.S., Owens, J.P., Stanford, S.D., and Stone, B.D., 2000, Surficial geologic map of central and southern New Jersey: U.S. Geological Survey Miscellaneous Investigations Series Map I-2540-D, scale 1:100,000.

Owens, J.P., and Minard, J.P., 1964, Pre-Quaternary geology of the Pemberton quadrangle, New Jersey: U.S. Geological Survey Geologic Quadrangle Map GQ-262, scale 1:24,000. 
Owens, J.P., Sugarman, P.J., Sohl, N.F., Parker, R.A., Houghton, H.F., Volkert, R.A., Drake, A.A., Jr., and Orndorff, R.C., 1999, Bedrock geologic map of central and southern New Jersey: U.S. Geological Survey Miscellaneous Investigations Series Map I-2540-B, scale 1:100,000.

Reilly, T.J., Romanok, K.M., Tessler, Steven, and Fischer, J.M., 2010, Assessment of physical, chemical, and hydrologic factors affecting the infiltration of treated wastewater in the New Jersey Coastal Plain, with emphasis on the Hammonton Land Application Facility: U.S. Geological Survey Scientific Investigations Report 2010-5006, 72 p.

Schoeneberger, P.J., Wysocki, D.A., and Benham, E.C., 2012, Field book for describing and sampling soils, version 3.0: U.S. Department of Agriculture, Natural Resource Conservation Service, National Survey Center, 300 p.

Sugarman, P.J., Miller, K.G., Browning, J.V., Kulpecz, A.A., McLaughlin, P.P, Jr., and Monteverde, D.H., 2005, Hydrostratigraphy of the New Jersey Coastal Plain: Sequences and facies predict continuity of aquifers and confining units: Stratigraphy, v. 2, no. 3, p. 259-275.

Watt, M.K., Kane, A.C., Charles, E.G., and Storck, D.A., 2002, Hydrology of the unconfined aquifer system, Rancocas Creek area, Rancocas, Crosswicks, Assunpink, Blacks, and Crafts Creek Basins, New Jersey, 1996: U.S. Geological Survey Water-Resources Investigations Report 2002-4280, $5 \mathrm{pl}$.

Zapecza, O.S, 1989, Hydrogeologic framework of the New Jersey Coastal Plain: U.S. Geological Survey Professional Paper 1404-B, 49 p., 24 pl. 


\section{Appendix 1}

Ground-penetrating radar (GPR) profile images from the Joint Base McGuire-Dix-Lakehurst Land Application Site, New Jersey. No assumption was made with respect to ground velocity. A direct current (DC) removal filter with start sample 660 was applied to all GPR data for calculation of DC level. 


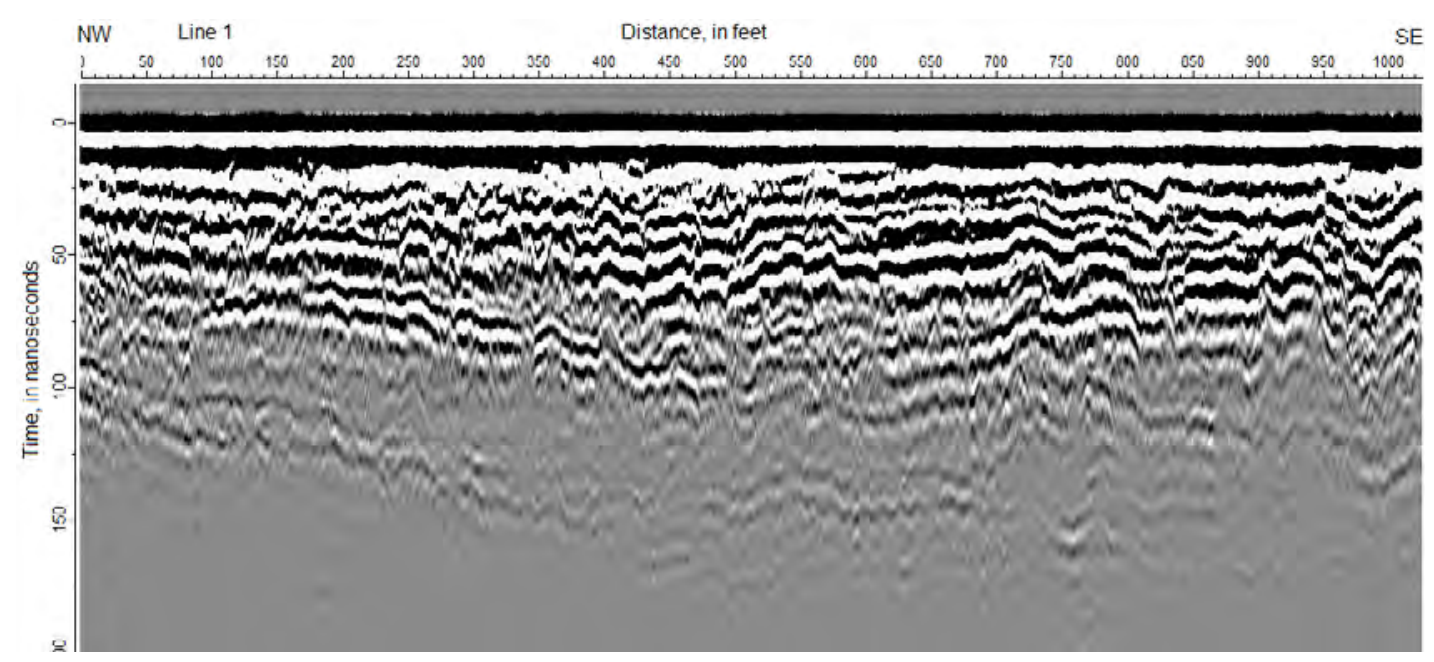

Figure 1-1. Ground-penetrating radar (GPR) profile, line 1, from the Joint Base McGuire-Dix-Lakehurst Land Application Site, New Jersey. No assumption was made with respect to ground velocity. A direct current (DC) removal filter with start sample 660 was applied to all GPR data for calculation of DC level. Vertical scale is time, in nanoseconds. Horizontal scale is distance, in feet.

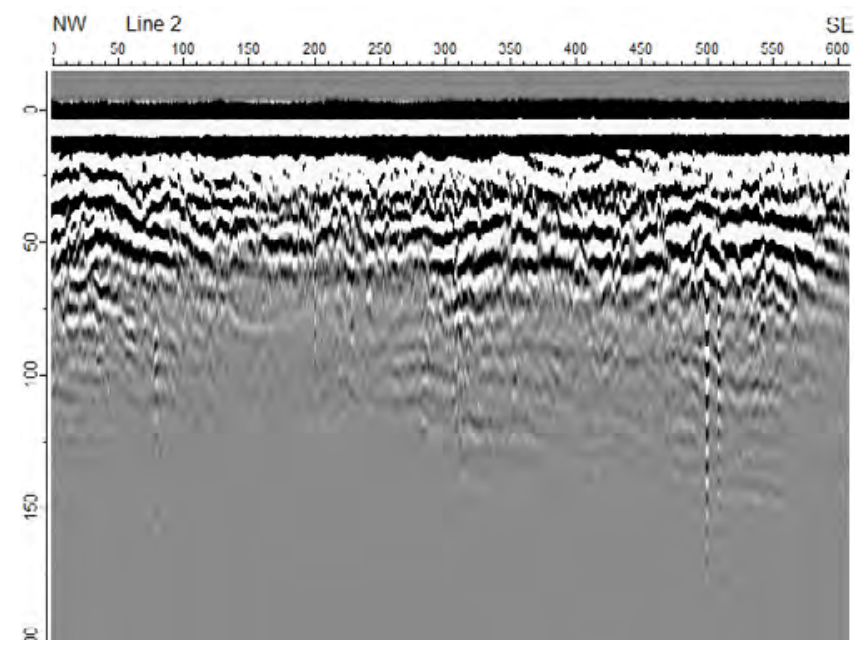

Figure 1-2. Ground-penetrating radar (GPR) profile, line 2, from the Joint Base McGuire-Dix-Lakehurst Land Application Site, New Jersey. No assumption was made with respect to ground velocity. A direct current (DC) removal filter with start sample 660 was applied to all GPR data for calculation of DC level. Vertical scale is time, in nanoseconds. Horizontal scale is distance, in feet. 

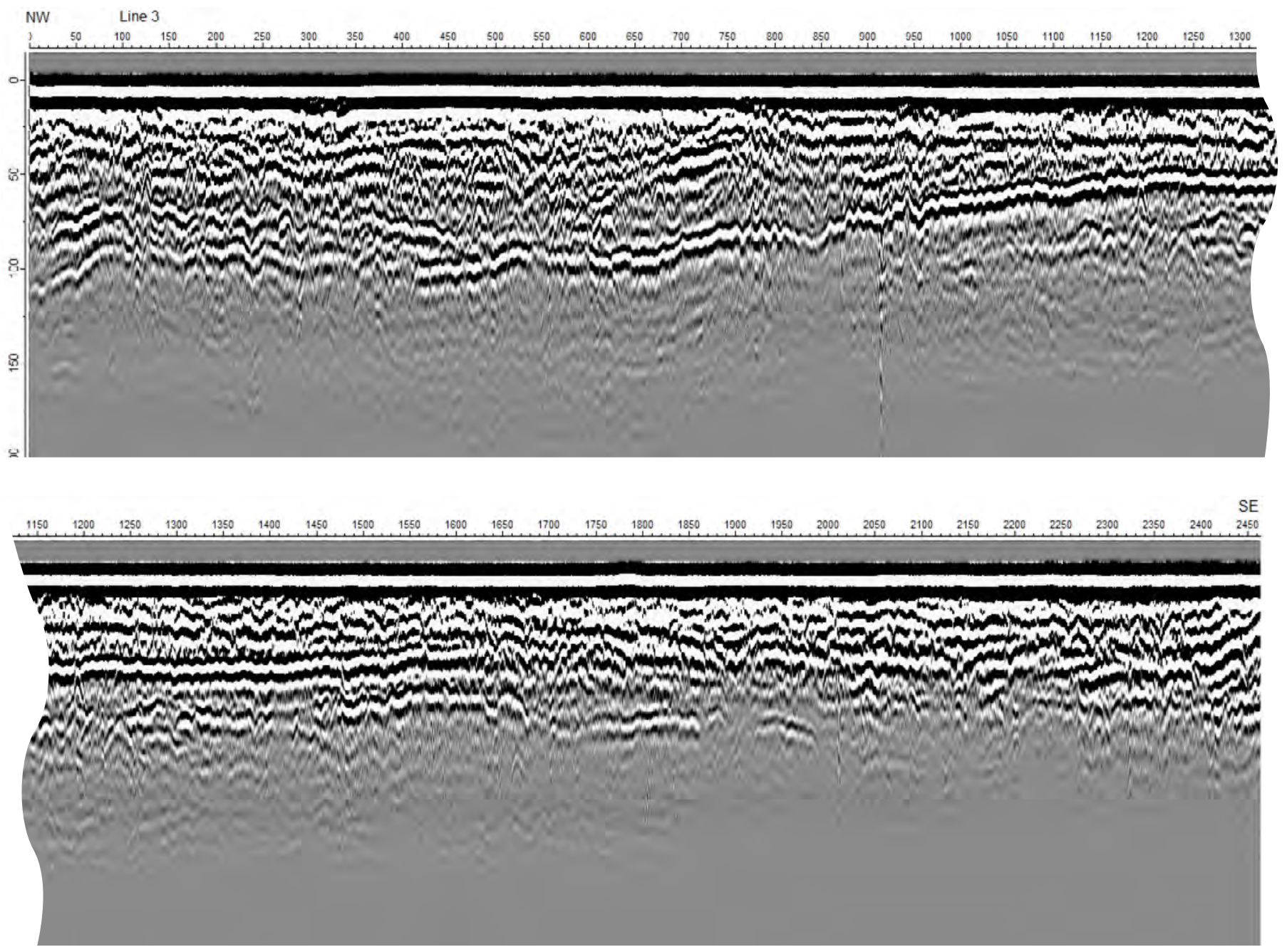

Figure 1-3. Ground-penetrating radar (GPR) profile, line 3, from the Joint Base McGuire-Dix-Lakehurst Land Application Site, New Jersey. No assumption was made with respect to ground velocity. A direct current (DC) removal filter with start sample 660 was applied to all GPR data for calculation of DC level. Vertical scale is time, in nanoseconds. Horizontal scale is distance, in feet. 


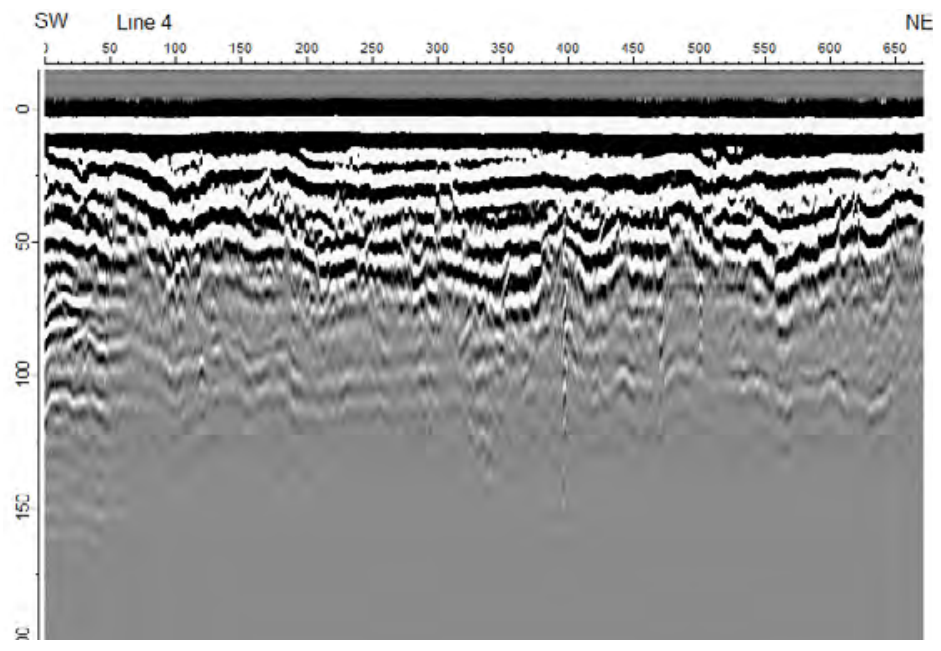

Figure 1-4. Ground-penetrating radar (GPR) profile, line 4, from the Joint Base McGuire-Dix-Lakehurst Land Application Site, New Jersey. No assumption was made with respect to ground velocity. A direct current $(D C)$ removal filter with start sample 660 was applied to all GPR data for calculation of DC level. Vertical scale is time, in nanoseconds. Horizontal scale is distance, in feet.

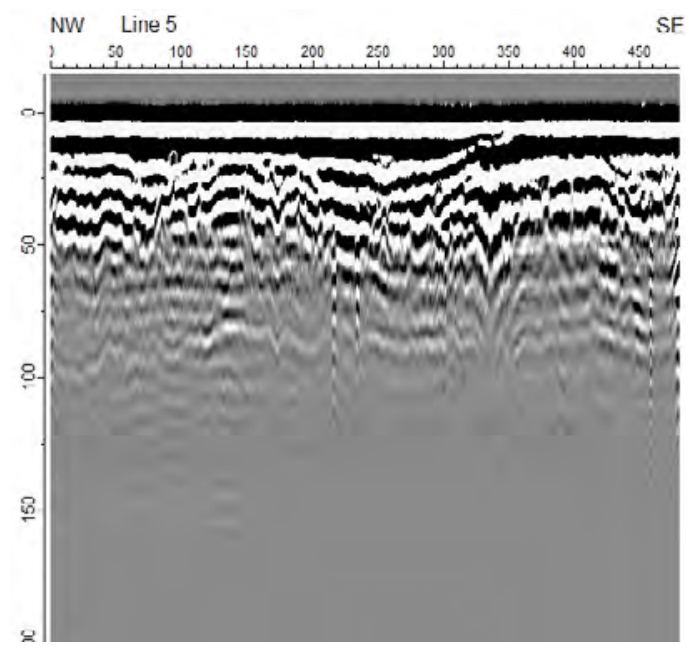

Figure 1-5. Ground-penetrating radar (GPR) profile, line 5, from the Joint Base McGuire-DixLakehurst Land Application Site, New Jersey. No assumption was made with respect to ground velocity. A direct current (DC) removal filter with start sample 660 was applied to all GPR data for calculation of DC level. Vertical scale is time, in nanoseconds. Horizontal scale is distance, in feet.

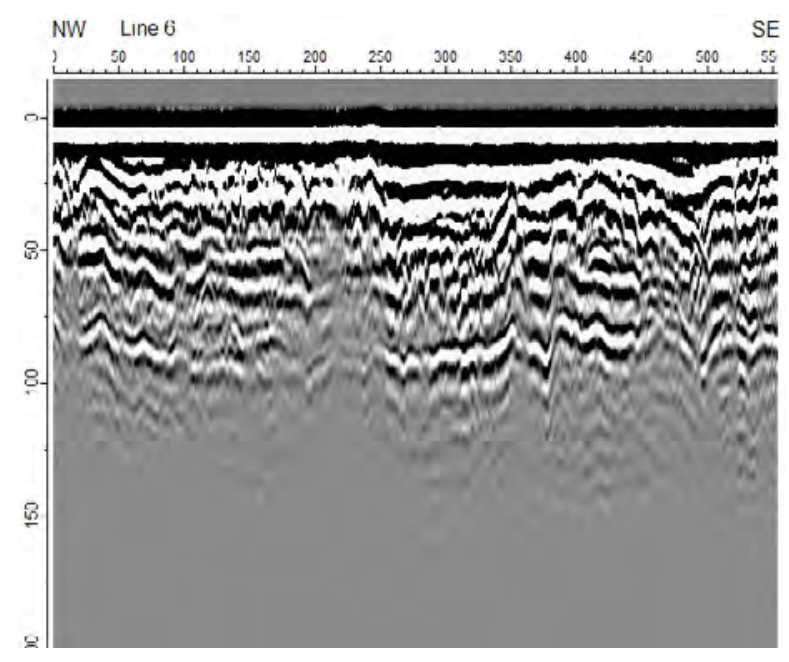

Figure 1-6. Ground-penetrating radar (GPR) profile, line 6, from the Joint Base McGuire-Dix-Lakehurst Land Application Site, New Jersey. No assumption was made with respect to ground velocity. A direct current (DC) removal filter with start sample 660 was applied to all GPR data for calculation of DC level. Vertical scale is time, in nanoseconds. Horizontal scale is distance, in feet. 


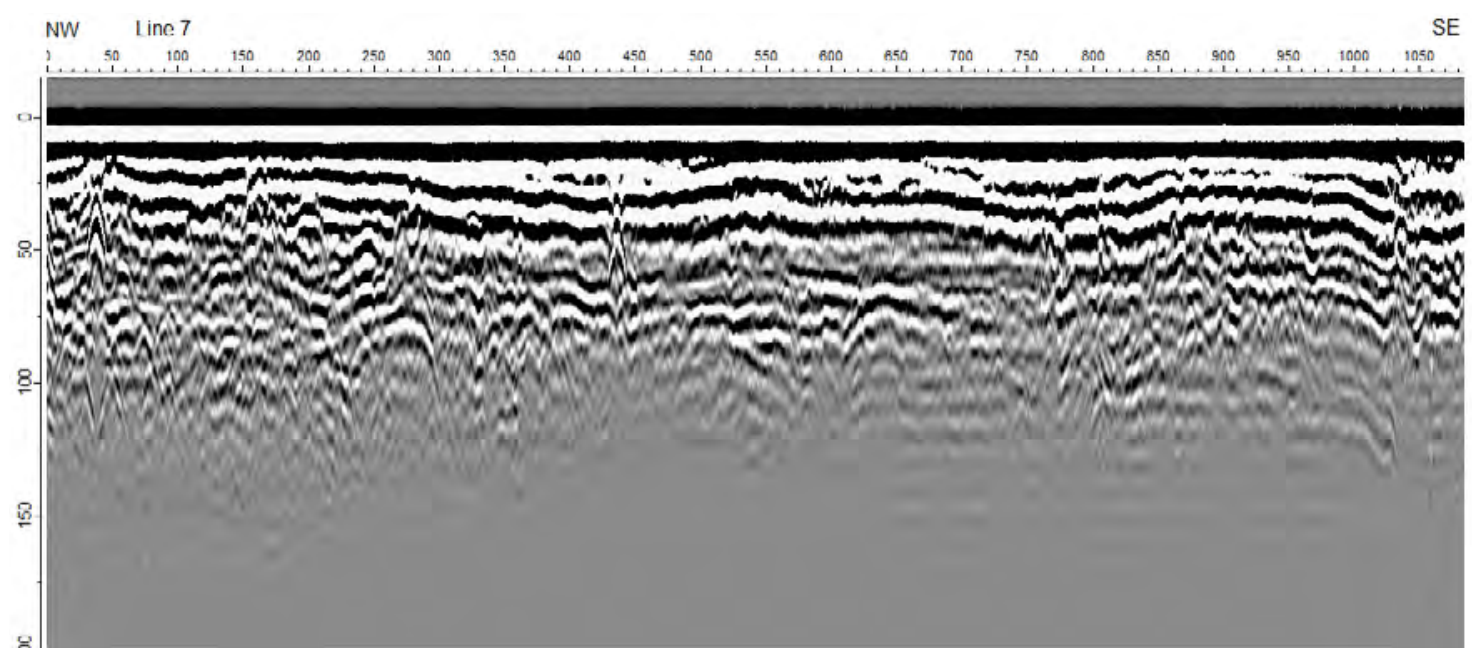

Figure 1-7. Ground-penetrating radar (GPR) profile, line 7, from the Joint Base McGuire-Dix-Lakehurst Land Application Site, New Jersey. No assumption was made with respect to ground velocity. A direct current (DC) removal filter with start sample 660 was applied to all GPR data for calculation of DC level. Vertical scale is time, in nanoseconds. Horizontal scale is distance, in feet.

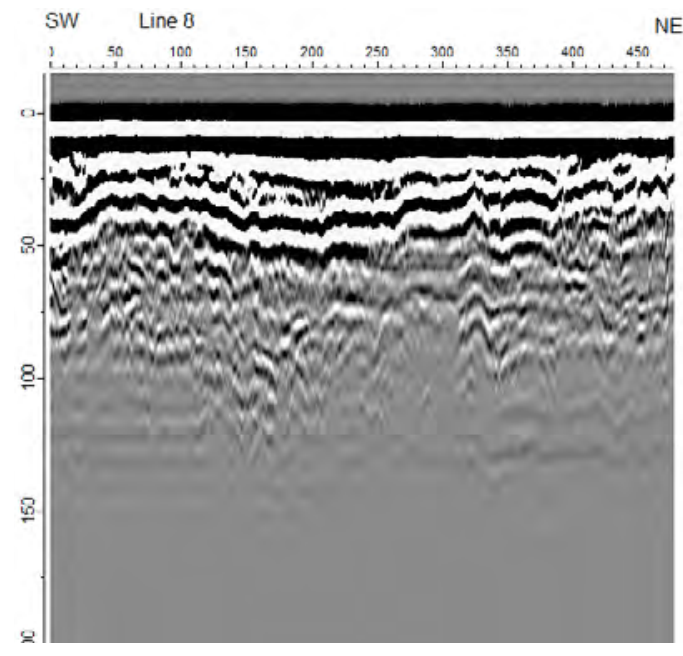

Figure 1-8. Ground-penetrating radar (GPR) profile, line 8, from the Joint Base McGuire-DixLakehurst Land Application Site, New Jersey. No assumption was made with respect to ground velocity. A direct current (DC) removal filter with start sample 660 was applied to all GPR data for calculation of DC level. Vertical scale is time, in nanoseconds. Horizontal scale is distance, in feet. 

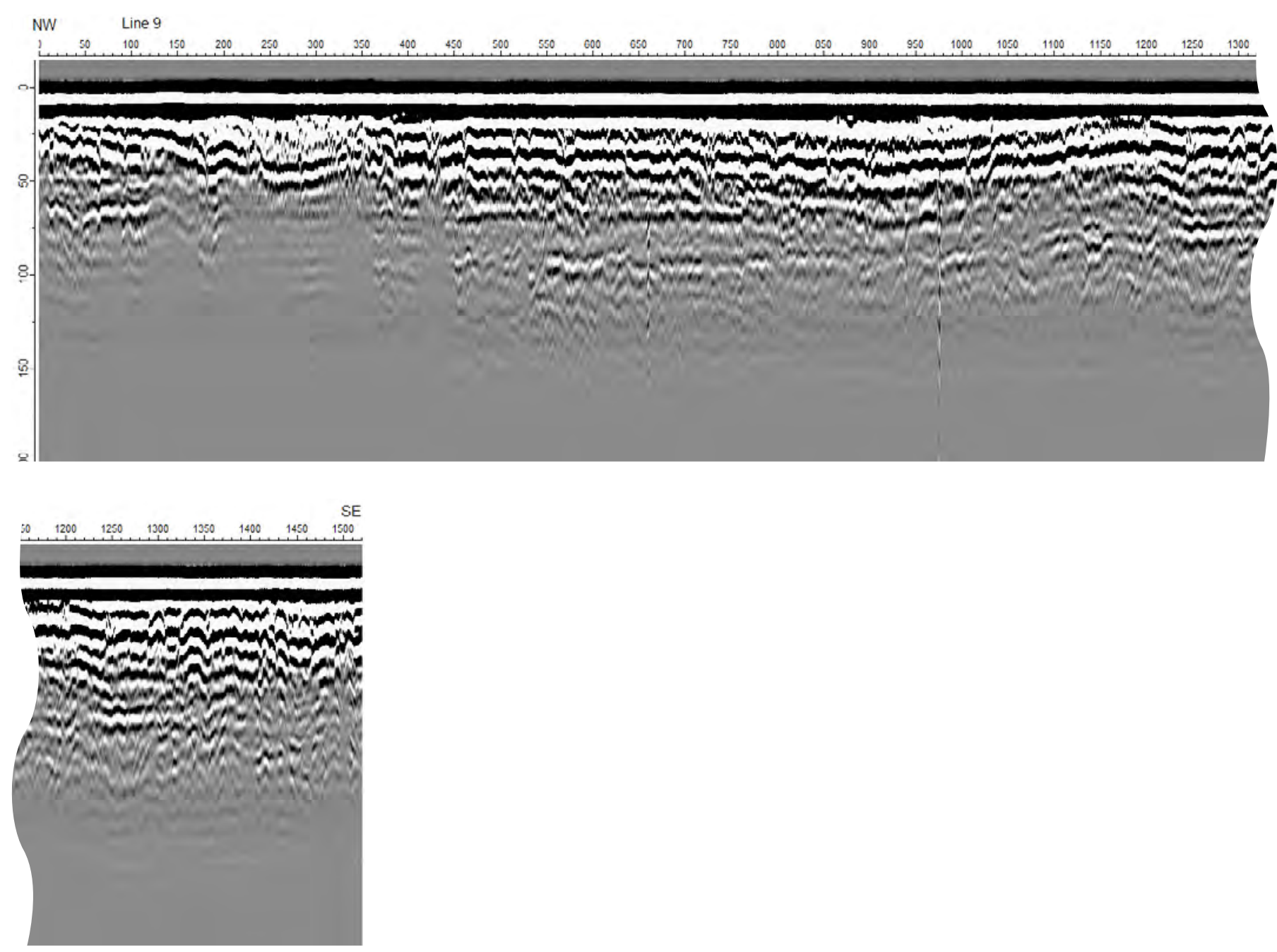

Figure 1-9. Ground-penetrating radar (GPR) profile, line 9, from the Joint Base McGuire-Dix-Lakehurst Land Application Site, New Jersey. No assumption was made with respect to ground velocity. A direct current (DC) removal filter with start sample 660 was applied to all GPR data for calculation of DC level. Vertical scale is time, in nanoseconds. Horizontal scale is distance, in feet. 


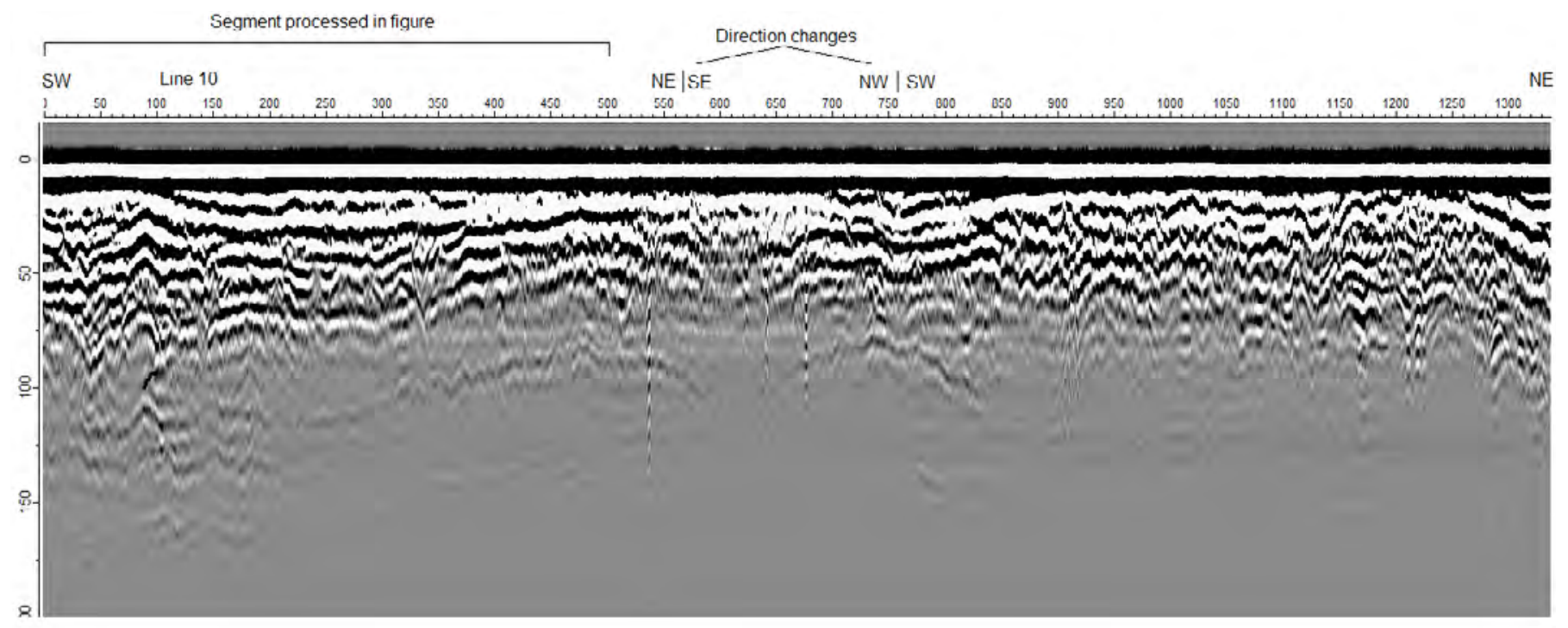

Figure 1-10. Ground-penetrating radar (GPR) profile, line 10, from the Joint Base McGuire-Dix-Lakehurst Land Application Site, New Jersey. No assumption was made with respect to ground velocity. A direct current (DC) removal filter with start sample 660 was applied to all GPR data for calculation of DC level. Vertical scale is time, in nanoseconds. Horizontal scale is distance, in feet.

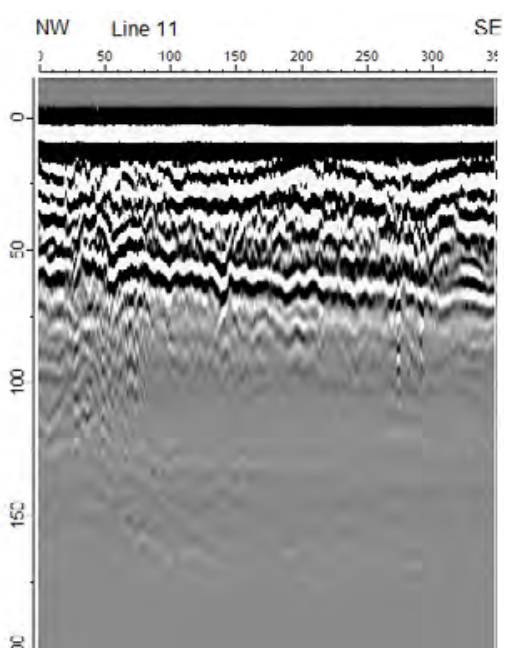

Figure 1-11. Ground-penetrating radar (GPR) profile, line 11, from the Joint Base McGuire-Dix-Lakehurst Land Application Site, New Jersey. No assumption was made with respect to ground velocity. A direct current (DC) removal filter with start sample 660 was applied to all GPR data for calculation of DC level. Vertical scale is time, in nanoseconds. Horizontal scale is distance, in feet.

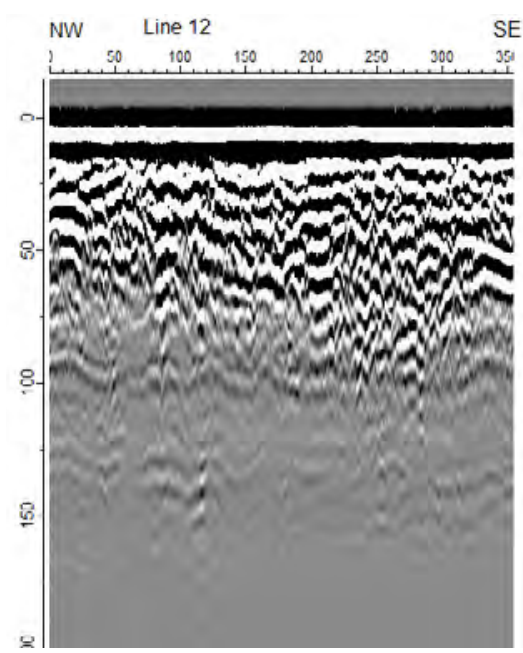

Figure 1-12. Ground-penetrating radar (GPR) profile, line 12, from the Joint Base McGuire-Dix-Lakehurst Land Application Site, New Jersey. No assumption was made with respect to ground velocity. A direct current (DC) removal filter with start sample 660 was applied to all GPR data for calculation of DC level. Vertical scale is time, in nanoseconds. Horizontal scale is distance, in feet.

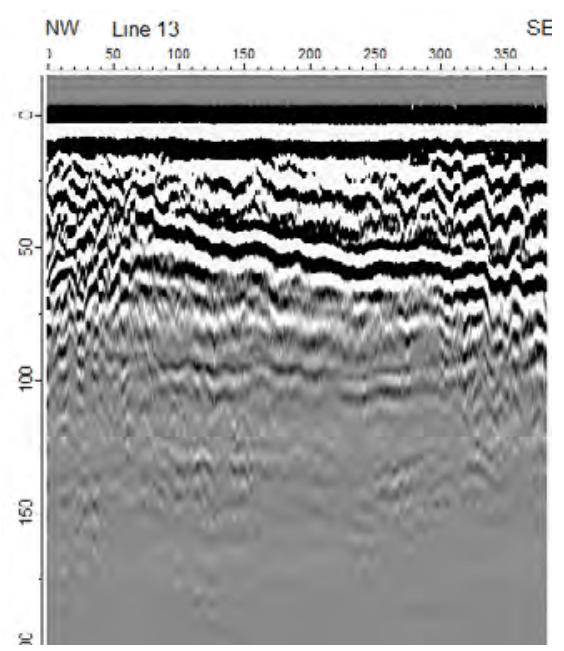

Figure 1-13. Ground-penetrating radar (GPR) profile, line 13, from the Joint Base McGuire-Dix-Lakehurst Land Application Site, New Jersey. No assumption was made with respect to ground velocity. A direct current (DC) removal filter with start sample 660 was applied to all GPR data for calculation of DC level. Vertical scale is time, in nanoseconds. Horizontal scale is distance, in feet. 


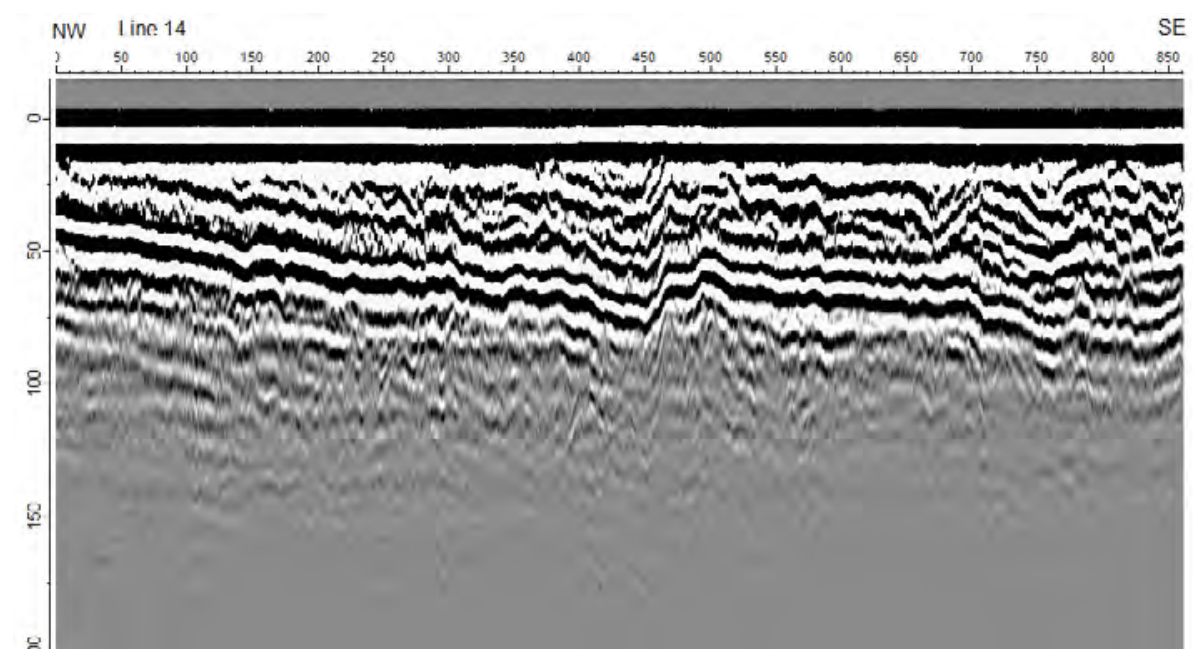

Figure 1-14. Ground-penetrating radar (GPR) profile, line 14, from the Joint Base McGuire-Dix-Lakehurst Land Application Site, New Jersey. No assumption was made with respect to ground velocity. A direct current (DC) removal filter with start sample 660 was applied to all GPR data for calculation of DC level. Vertical scale is time, in nanoseconds. Horizontal scale is distance, in feet.

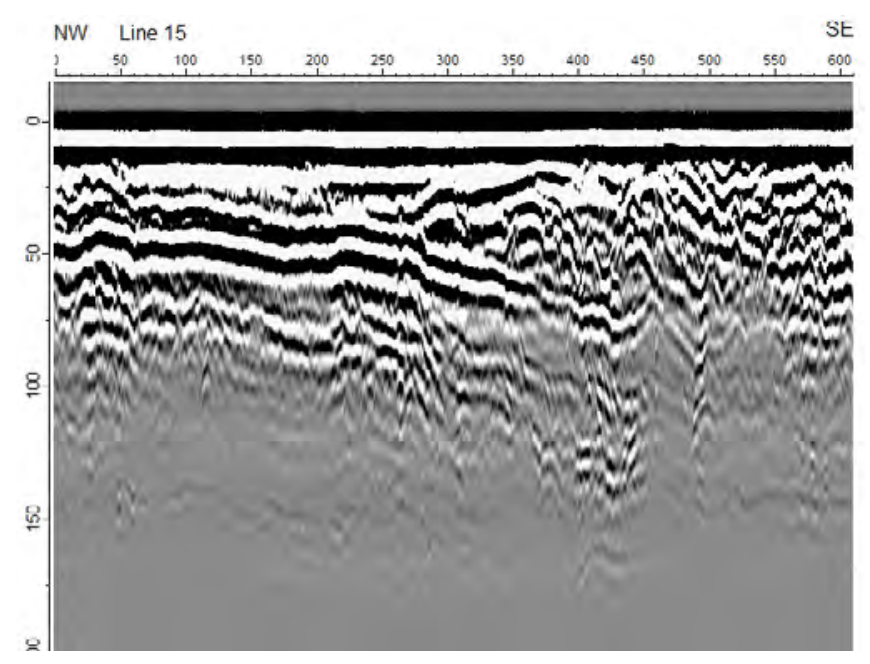

Figure 1-15. Ground-penetrating radar (GPR) profile, line 15, from the Joint Base McGuire-Dix-Lakehurst Land Application Site, New Jersey. No assumption was made with respect to ground velocity. A direct current (DC) removal filter with start sample 660 was applied to all GPR data for calculation of DC level. Vertical scale is time, in nanoseconds. Horizontal scale is distance, in feet.

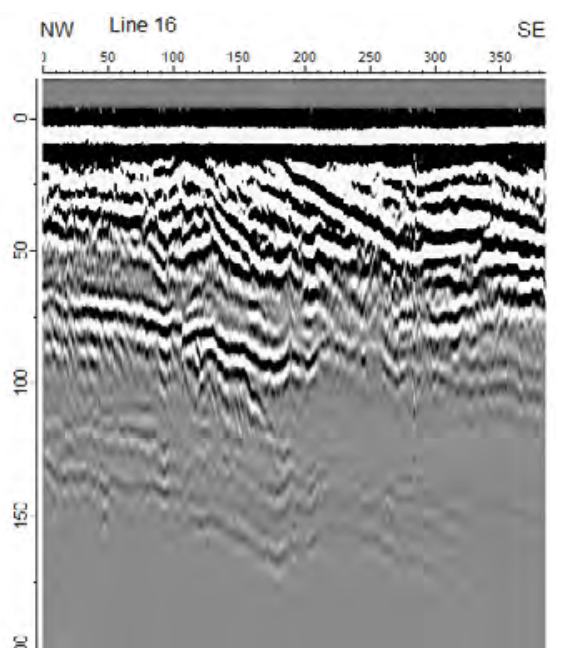

Figure 1-16. Ground-penetrating radar (GPR) profile, line 16, from the Joint Base McGuire-Dix-Lakehurst Land Application Site, New Jersey. No assumption was made with respect to ground velocity. A direct current (DC) removal filter with start sample 660 was applied to all GPR data for calculation of DC level. Vertical scale is time, in nanoseconds. Horizontal scale is distance, in feet. 


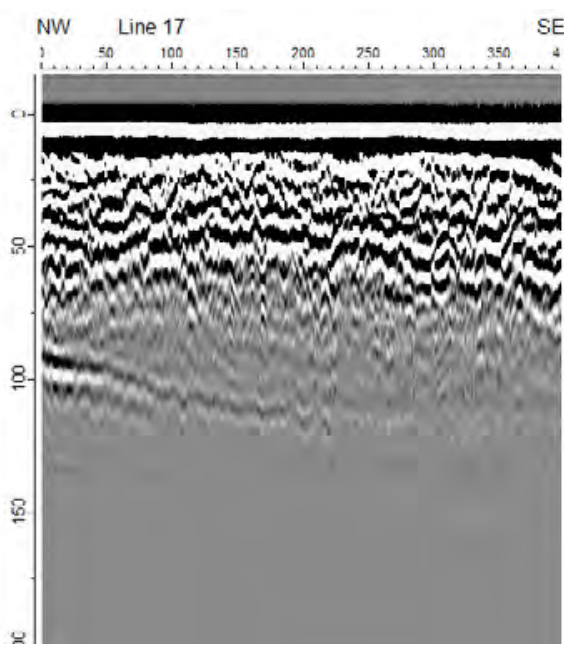

Figure 1-17. Ground-penetrating radar (GPR) profile, line 17, from the Joint Base McGuire-Dix-Lakehurst Land Application Site, New Jersey. No assumption was made with respect to ground velocity. A direct current (DC) removal filter with start sample 660 was applied to all GPR data for calculation of DC level. Vertical scale is time, in nanoseconds. Horizontal scale is distance, in feet.

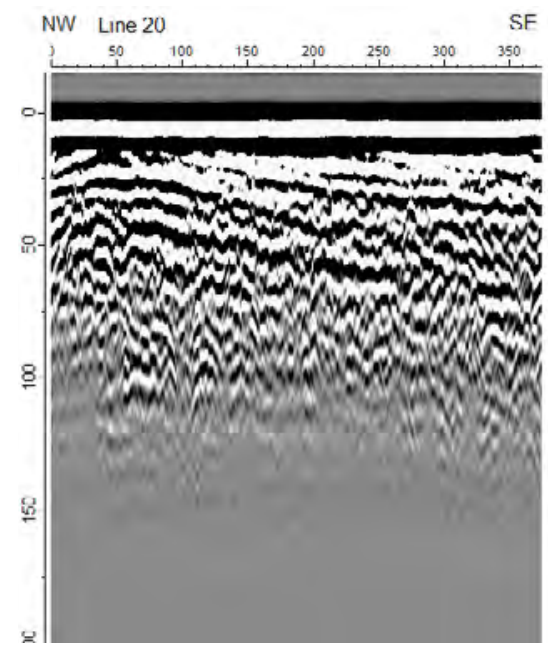

Figure 1-20. Ground-penetrating radar (GPR) profile, line 20, from the Joint Base McGuire-Dix-Lakehurst Land Application Site, New Jersey. No assumption was made with respect to ground velocity. A direct current (DC) removal filter with start sample 660 was applied to all GPR data for calculation of $D C$ level. Vertical scale is time, in nanoseconds. Horizontal scale is distance, in feet.

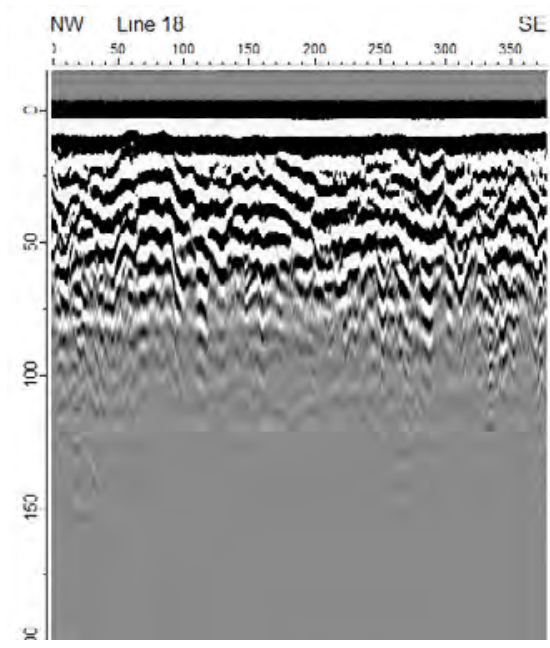

Figure 1-18. Ground-penetrating radar (GPR) profile, line 18, from the Joint Base McGuire-Dix-Lakehurst Land Application Site, New Jersey. No assumption was made with respect to ground velocity. A direct current (DC) removal filter with start sample 660 was applied to all GPR data for calculation of DC level. Vertical scale is time, in nanoseconds. Horizontal scale is distance, in feet.

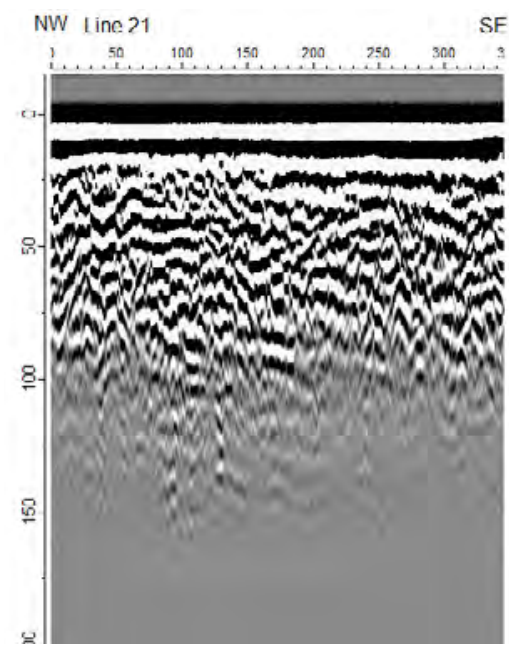

Figure 1-21. Ground-penetrating radar (GPR) profile, line 21, from the Joint Base McGuire-Dix-Lakehurst Land Application Site, New Jersey. No assumption was made with respect to ground velocity. A direct current (DC) removal filter with start sample 660 was applied to all GPR data for calculation of DC level. Vertical scale is time, in nanoseconds. Horizontal scale is distance, in feet.

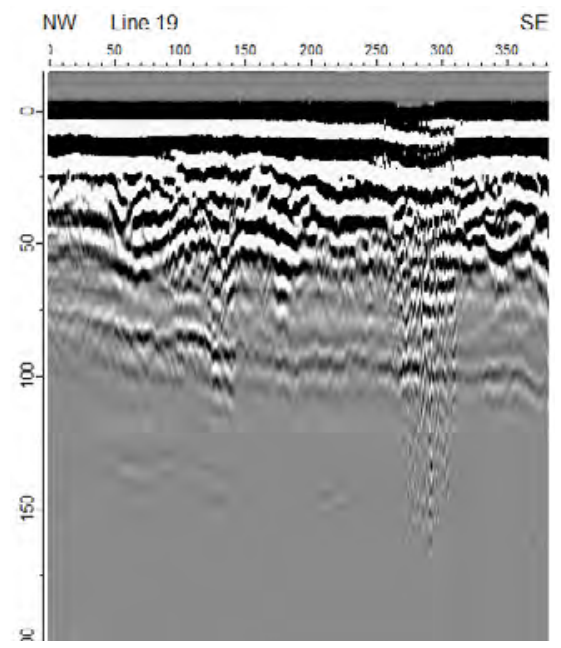

Figure 1-19. Ground-penetrating radar (GPR) profile, line 19, from the Joint Base McGuire-Dix-Lakehurst Land Application Site, New Jersey. No assumption was made with respect to ground velocity. A direct current (DC) removal filter with start sample 660 was applied to all GPR data for calculation of DC level. Vertical scale is time, in nanoseconds. Horizontal scale is distance, in feet.

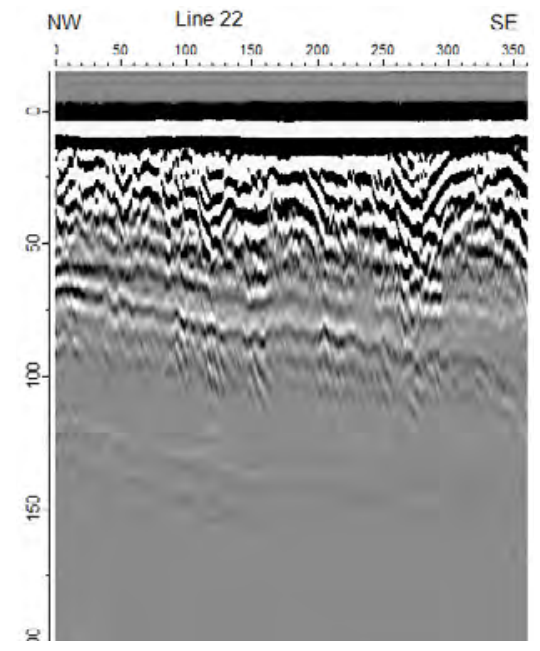

Figure 1-22. Ground-penetrating radar (GPR) profile, line 22, from the Joint Base McGuire-Dix-Lakehurst Land Application Site, New Jersey. No assumption was made with respect to ground velocity. A direct current (DC) removal filter with start sample 660 was applied to all GPR data for calculation of DC level. Vertical scale is time, in nanoseconds. Horizontal scale is distance, in feet. 


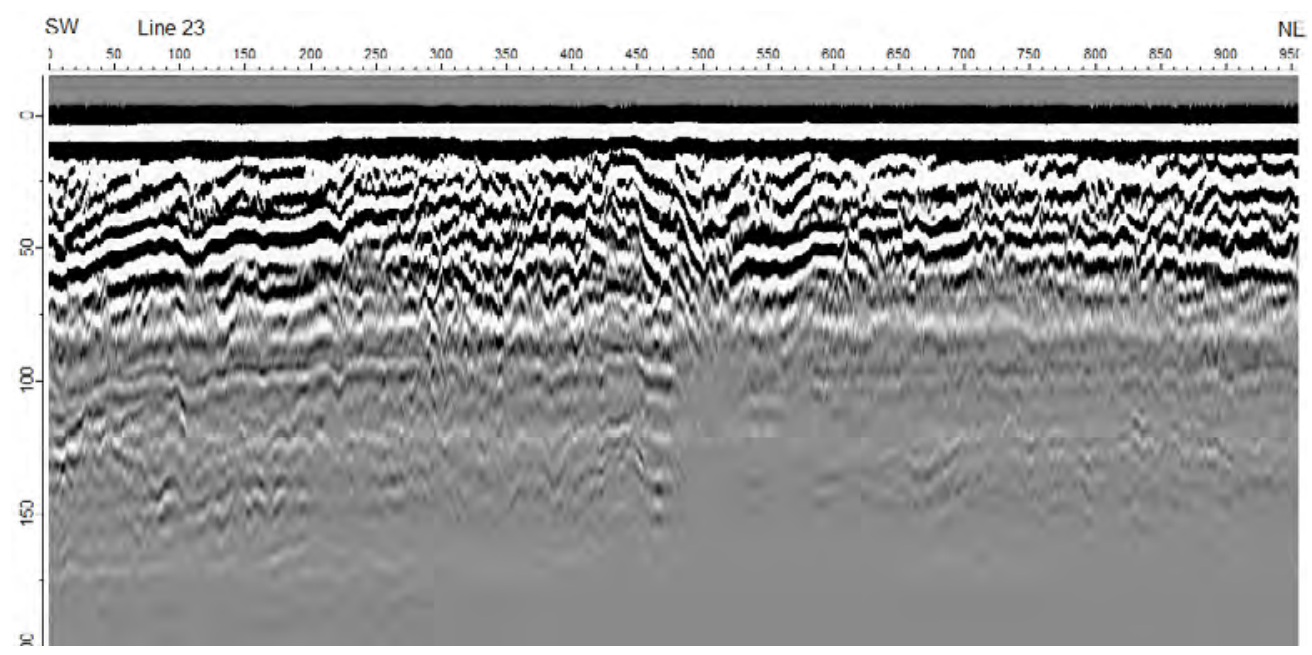

Figure 1-23. Ground-penetrating radar (GPR) profile, line 23, from the Joint Base McGuire-DixLakehurst Land Application Site, New Jersey. No assumption was made with respect to ground velocity. A direct current (DC) removal filter with start sample 660 was applied to all GPR data for calculation of DC level. Vertical scale is time, in nanoseconds. Horizontal scale is distance, in feet.

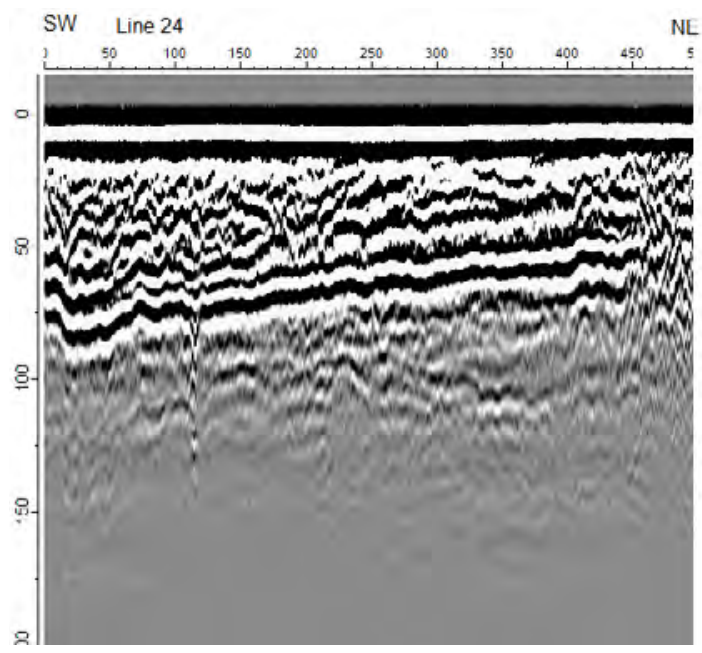

Figure 1-24. Ground-penetrating radar (GPR) profile, line 24, from the Joint Base McGuire-DixLakehurst Land Application Site, New Jersey. No assumption was made with respect to ground velocity. A direct current (DC) removal filter with start sample 660 was applied to all GPR data for calculation of DC level. Vertical scale is time, in nanoseconds. Horizontal scale is distance, in feet.

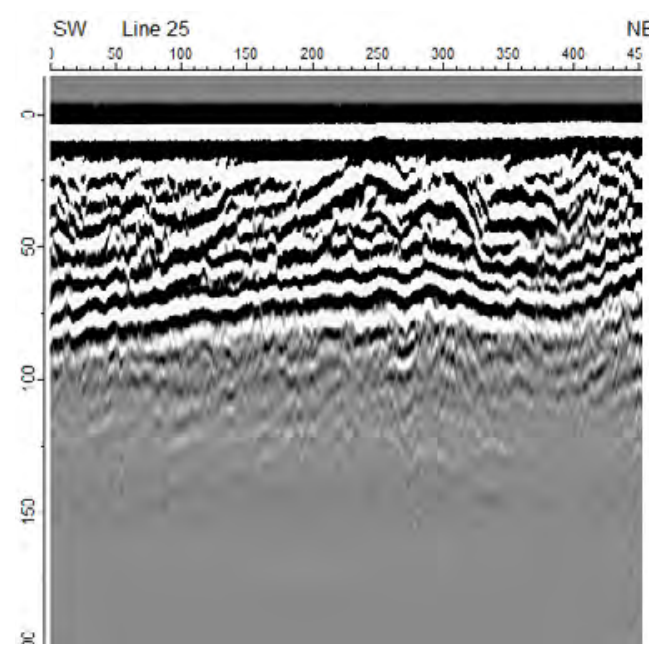

Figure 1-25. Ground-penetrating radar (GPR) profile, line 25, from the Joint Base McGuire-Dix-Lakehurst Land Application Site, New Jersey. No assumption was made with respect to ground velocity. A direct current (DC) removal filter with start sample 660 was applied to all GPR data for calculation of DC level. Vertical scale is time, in nanoseconds. Horizontal scale is distance, in feet. 


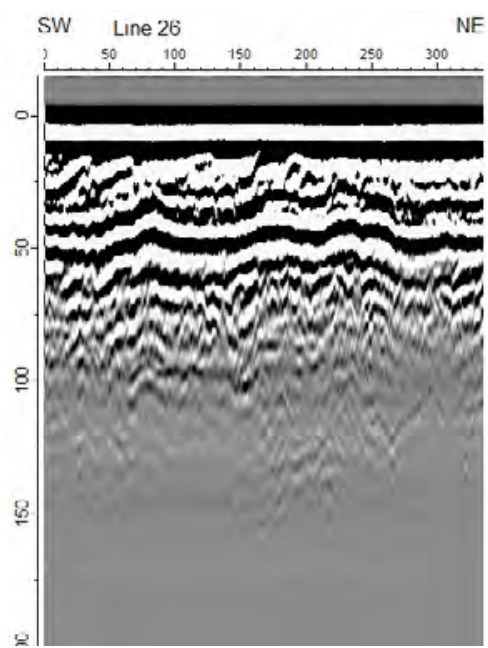

Figure 1-26. Ground-penetrating radar (GPR) profile, line 26 , from the Joint Base McGuire-Dix-Lakehurst Land Application Site, New Jersey. No assumption was made with respect to ground velocity. $A$ direct current (DC) removal filter with start sample 660 was applied to all GPR data for calculation of DC level. Vertical scale is time, in nanoseconds. Horizontal scale is distance, in feet.

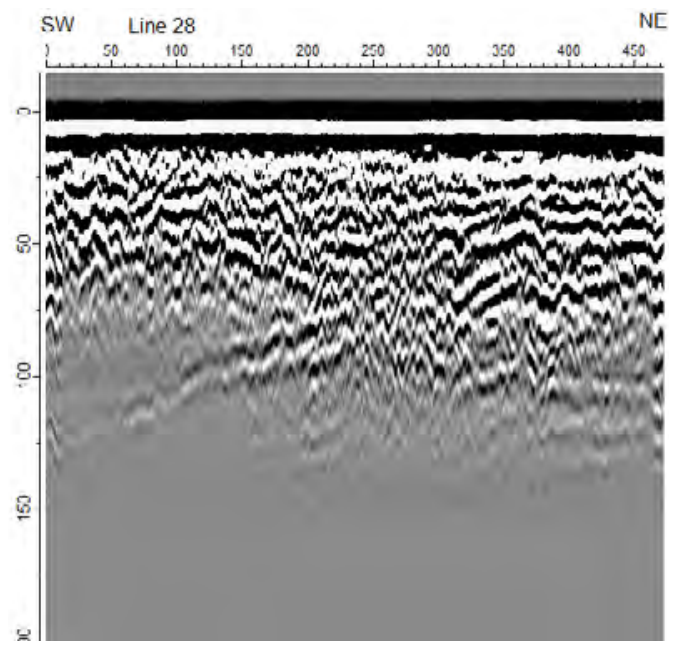

Figure 1-28. Ground-penetrating radar (GPR) profile, line 28, from the Joint Base McGuire-DixLakehurst Land Application Site, New Jersey. No assumption was made with respect to ground velocity. A direct current (DC) removal filter with start sample 660 was applied to all GPR data for calculation of DC level. Vertical scale is time, in nanoseconds. Horizontal scale is distance, in feet.

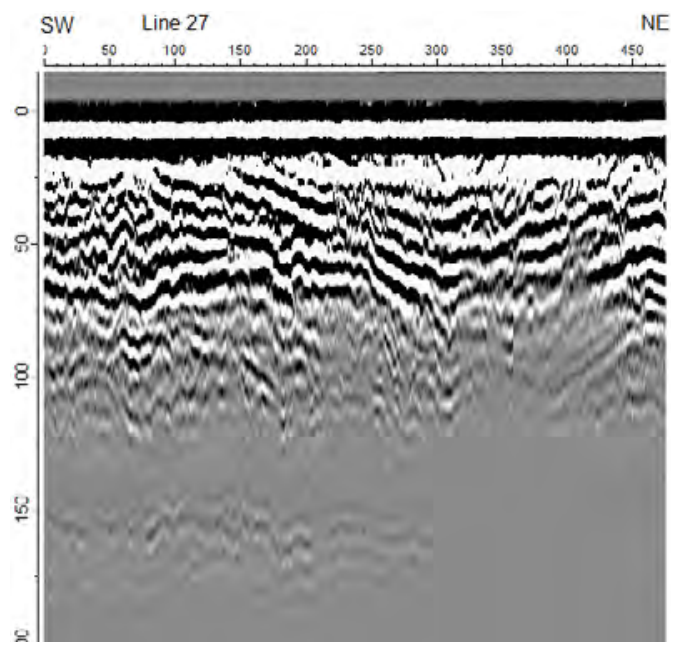

Figure 1-27. Ground-penetrating radar (GPR) profile, line 27, from the Joint Base McGuire-DixLakehurst Land Application Site, New Jersey. No assumption was made with respect to ground velocity. A direct current (DC) removal filter with start sample 660 was applied to all GPR data for calculation of DC level. Vertical scale is time, in nanoseconds. Horizontal scale is distance, in feet.

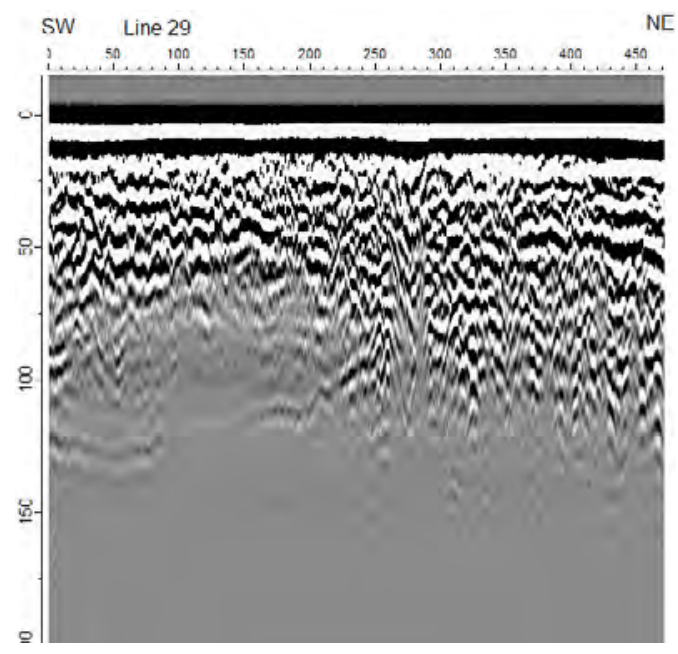

Figure 1-29. Ground-penetrating radar (GPR) profile, line 29, from the Joint Base McGuire-DixLakehurst Land Application Site, New Jersey. No assumption was made with respect to ground velocity. A direct current (DC) removal filter with start sample 660 was applied to all GPR data for calculation of DC level. Vertical scale is time, in nanoseconds. Horizontal scale is distance, in feet. 


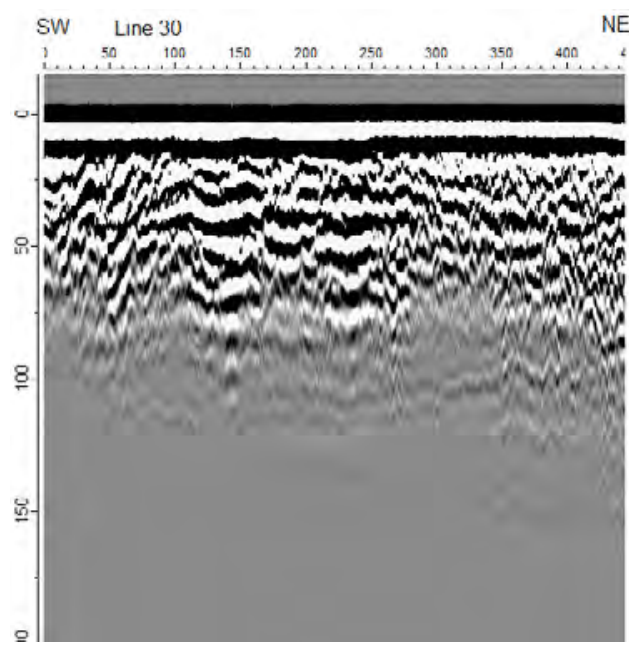

Figure 1-30. Ground-penetrating radar (GPR) profile, line 30, from the Joint Base McGuire-Dix-Lakehurst Land Application Site, New Jersey. No assumption was made with respect to ground velocity. A direct current (DC) removal filter with start sample 660 was applied to all GPR data for calculation of DC level. Vertical scale is time, in nanoseconds. Horizontal scale is distance, in feet.

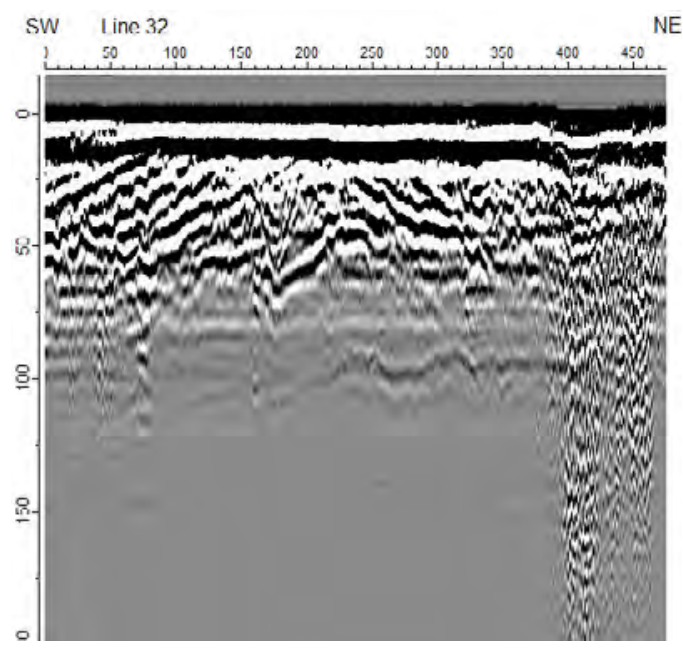

Figure 1-32. Ground-penetrating radar (GPR) profile, line 32, from the Joint Base McGuire-DixLakehurst Land Application Site, New Jersey. No assumption was made with respect to ground velocity. A direct current (DC) removal filter with start sample 660 was applied to all GPR data for calculation of DC level. Vertical scale is time, in nanoseconds. Horizontal scale is distance, in feet.

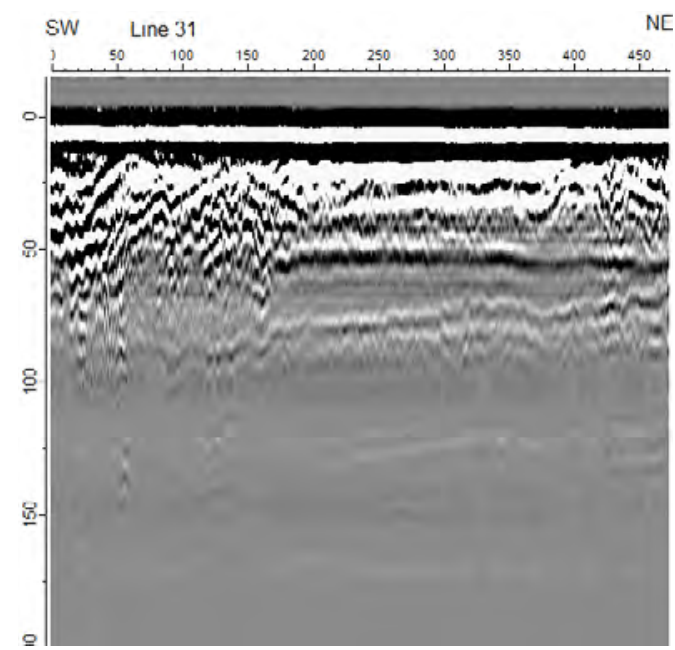

Figure 1-31. Ground-penetrating radar (GPR) profile, line 31, from the Joint Base McGuire-DixLakehurst Land Application Site, New Jersey. No assumption was made with respect to ground velocity. A direct current (DC) removal filter with start sample 660 was applied to all GPR data for calculation of DC level. Vertical scale is time, in nanoseconds. Horizontal scale is distance, in feet.

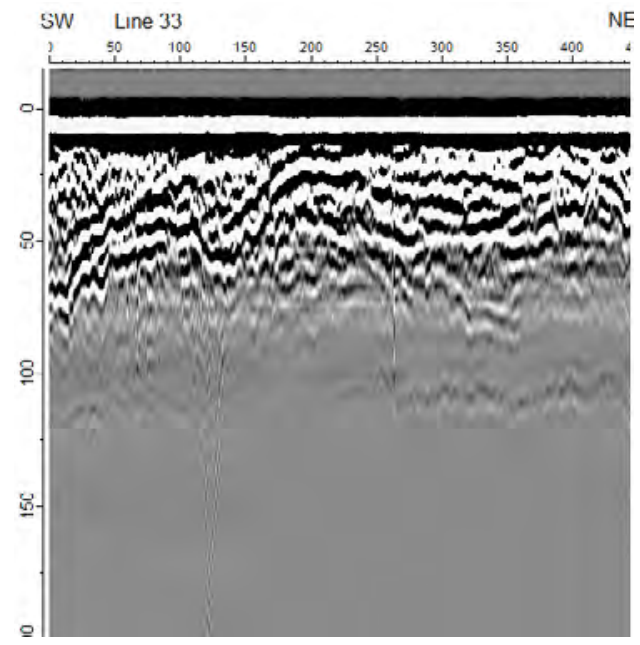

Figure 1-33. Ground-penetrating radar (GPR) profile, line 33, from the Joint Base McGuire-Dix-Lakehurst Land Application Site, New Jersey. No assumption was made with respect to ground velocity. A direct current (DC) removal filter with start sample 660 was applied to all GPR data for calculation of DC level. Vertical scale is time, in nanoseconds. Horizontal scale is distance, in feet. 


\section{Appendix 2}

Natural gamma logs of wells at the Joint Base McGuire-Dix-Lakehurst Land Application Site and vicinity, New Jersey. 

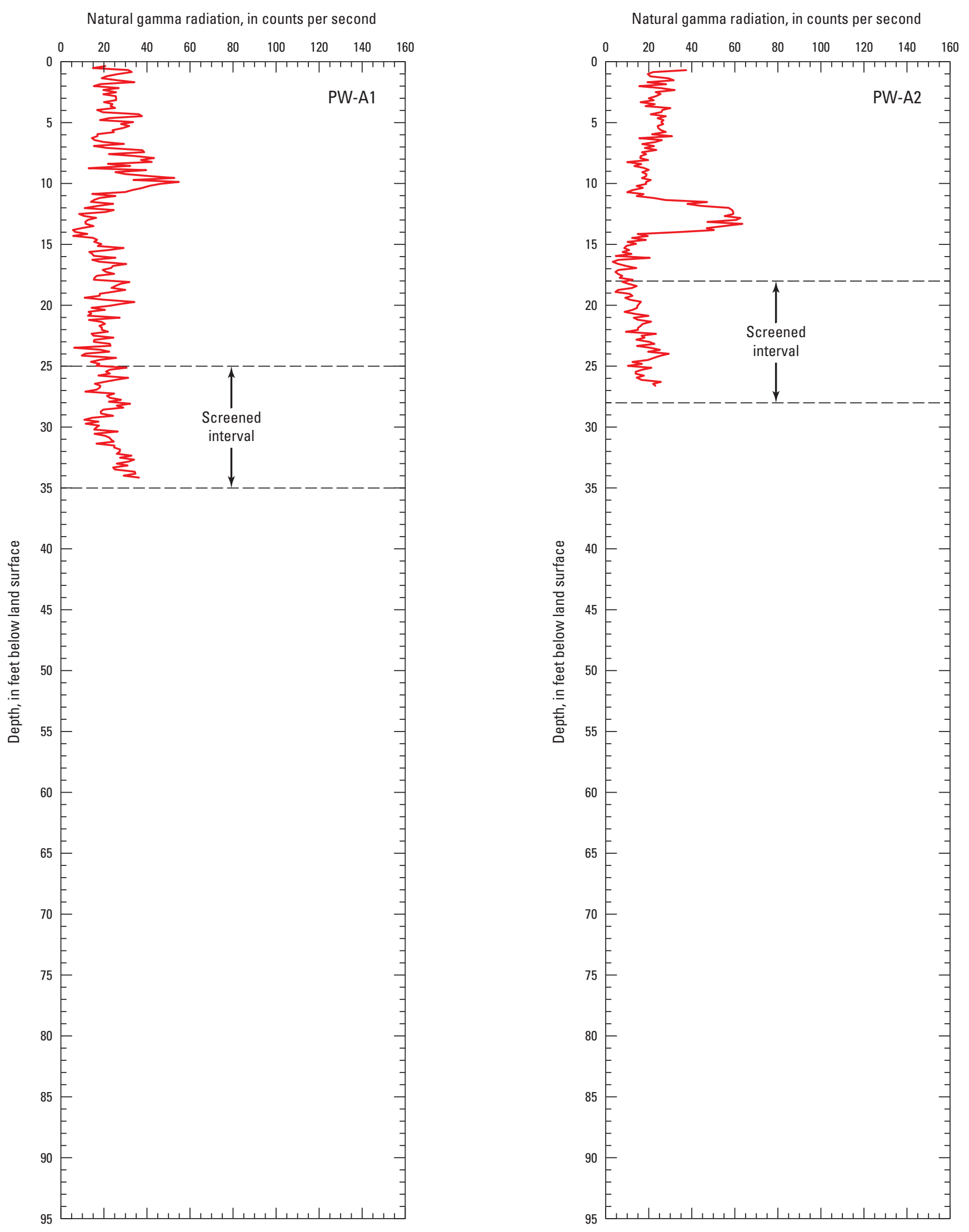

Figure 2-1. Natural gamma logs of wells at the Joint Base McGuire-Dix-Lakehurst Land Application Site and vicinity, New Jersey. 

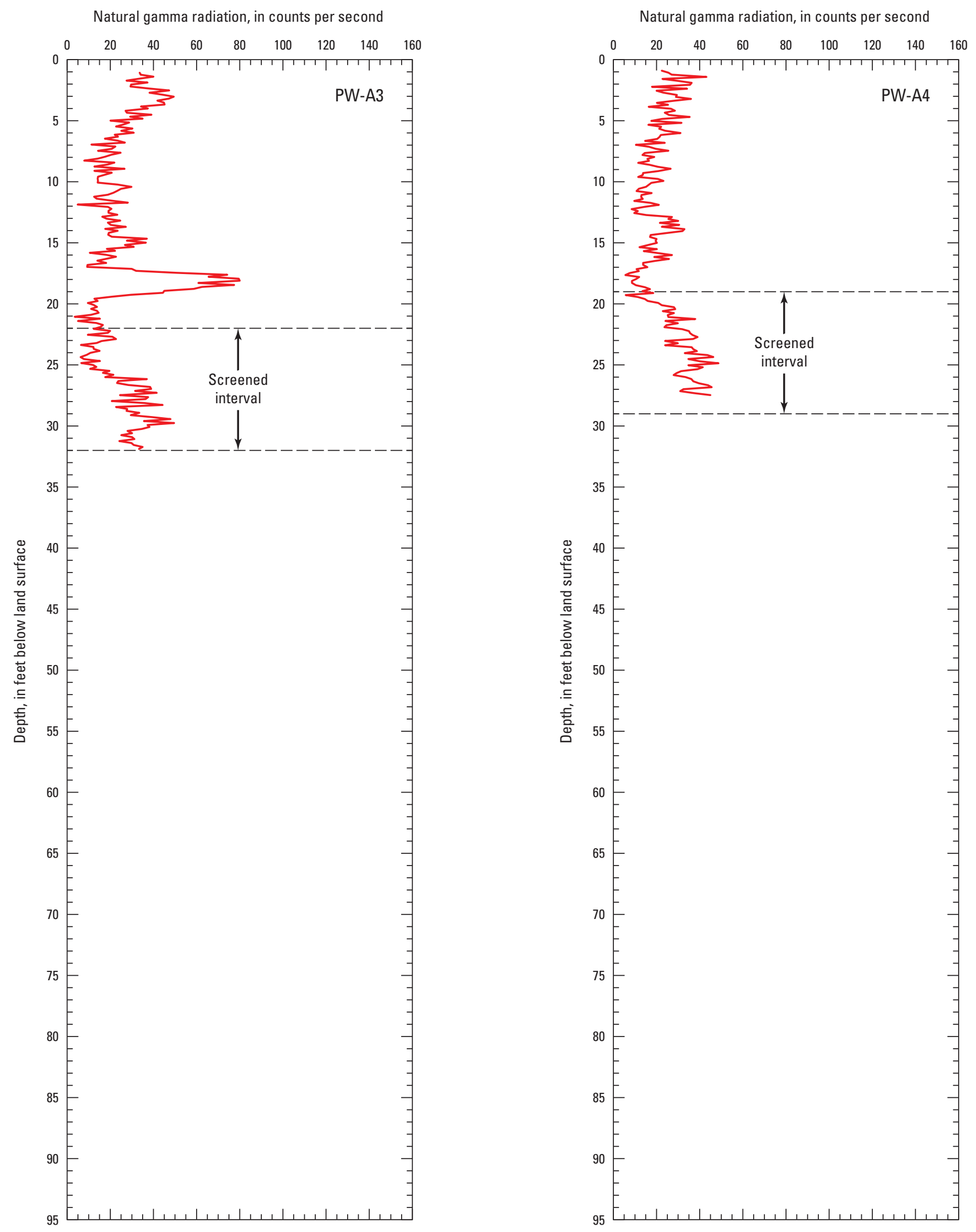

Figure 2-1. Natural gamma logs of wells at the Joint Base McGuire-Dix-Lakehurst Land Application Site and vicinity, New Jersey.-Continued 

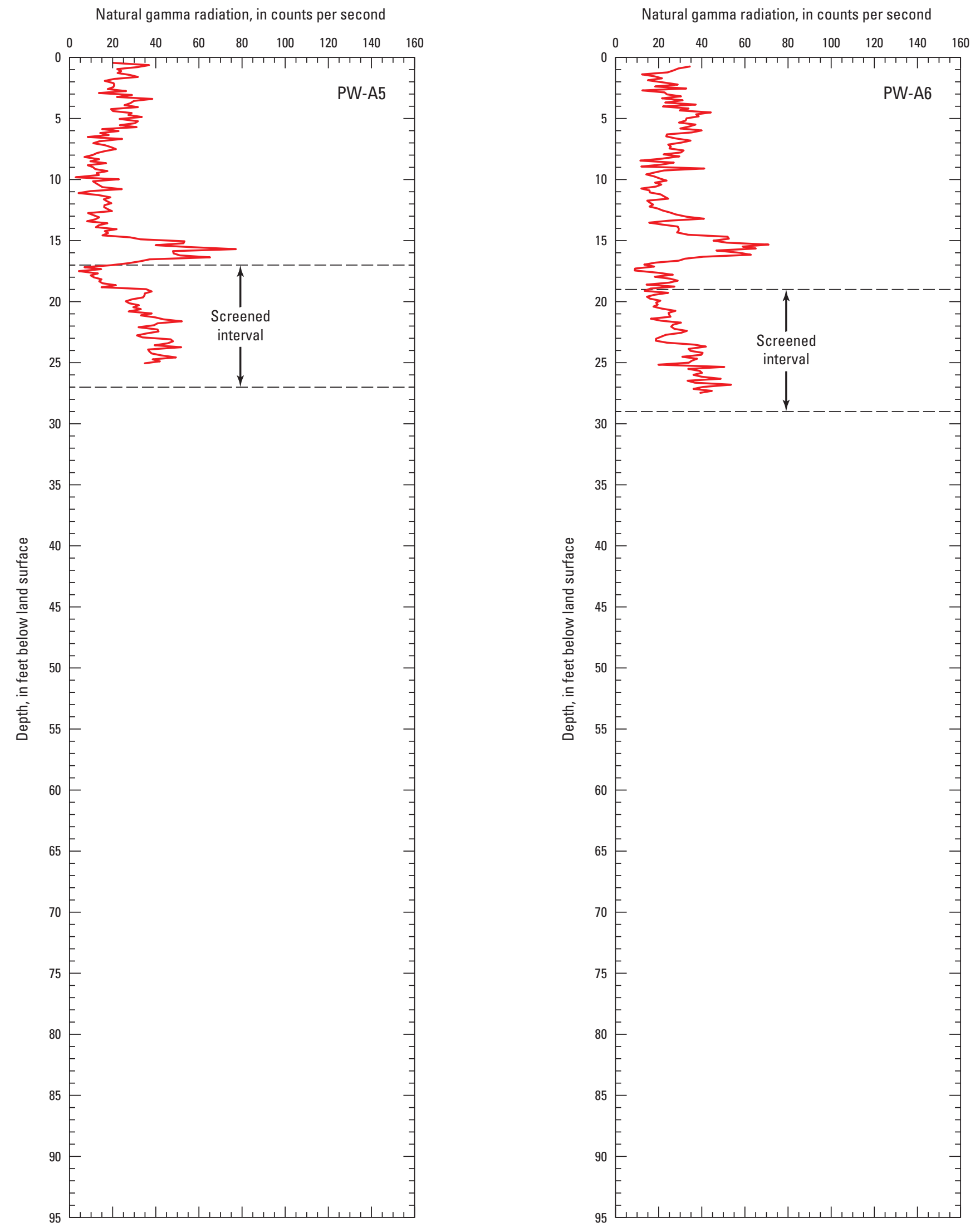

Figure 2-1. Natural gamma logs of wells at the Joint Base McGuire-Dix-Lakehurst Land Application Site and vicinity, New Jersey.-Continued 

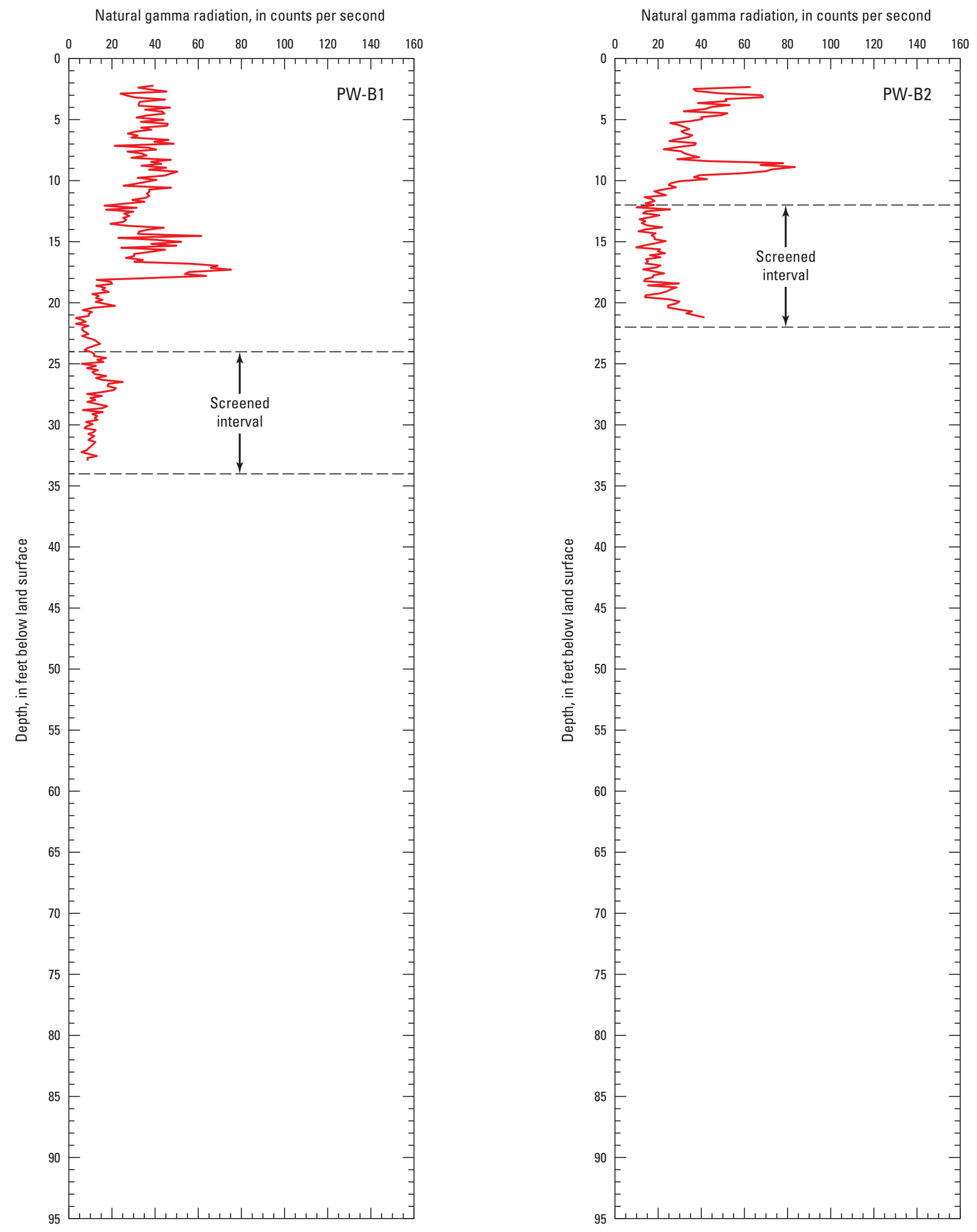

Figure 2-1. Natural gamma logs of wells at the Joint Base McGuire-Dix-Lakehurst Land Application Site and vicinity, New Jersey.-Continued 

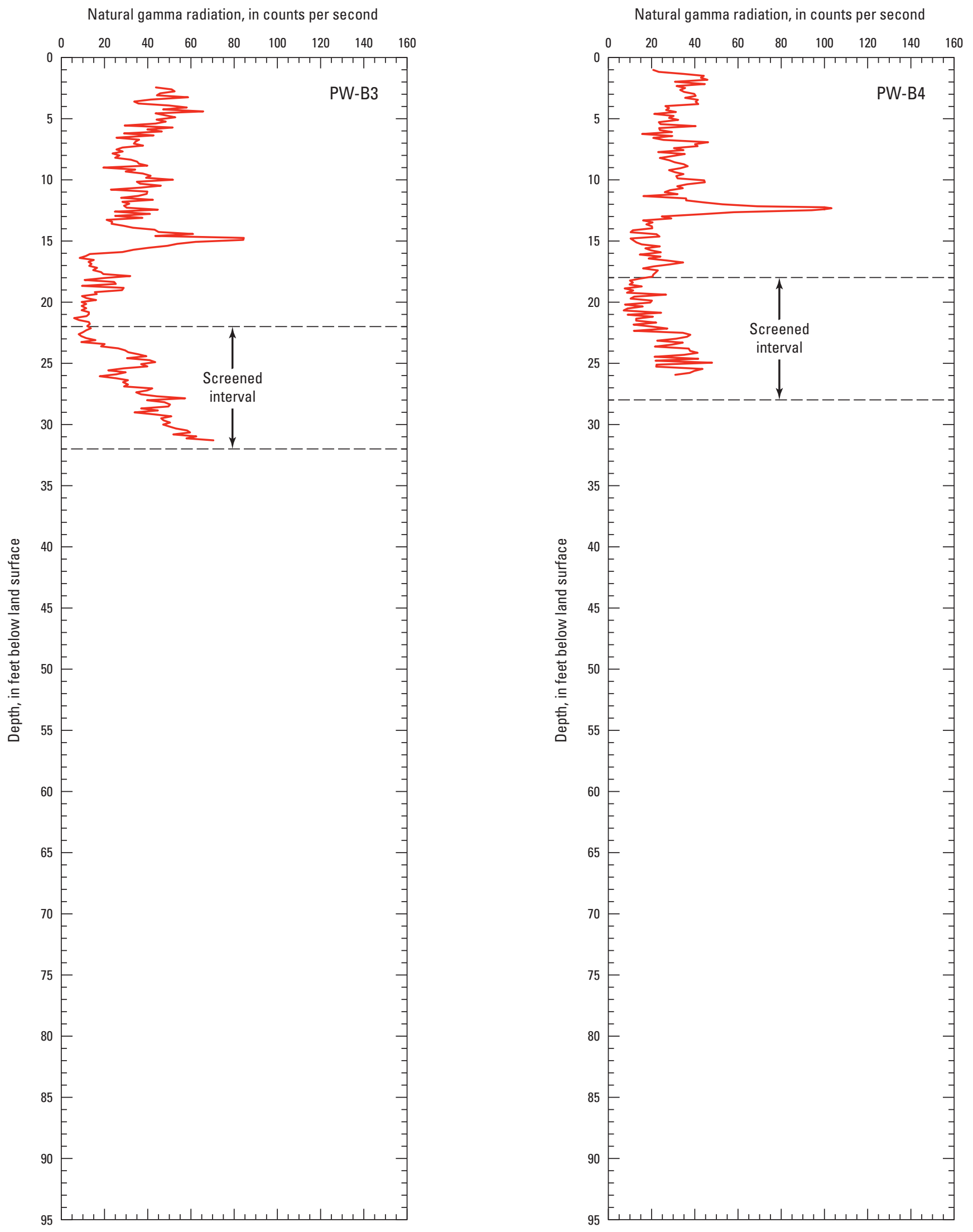

Figure 2-1. Natural gamma logs of wells at the Joint Base McGuire-Dix-Lakehurst Land Application Site and vicinity, New Jersey.-Continued 

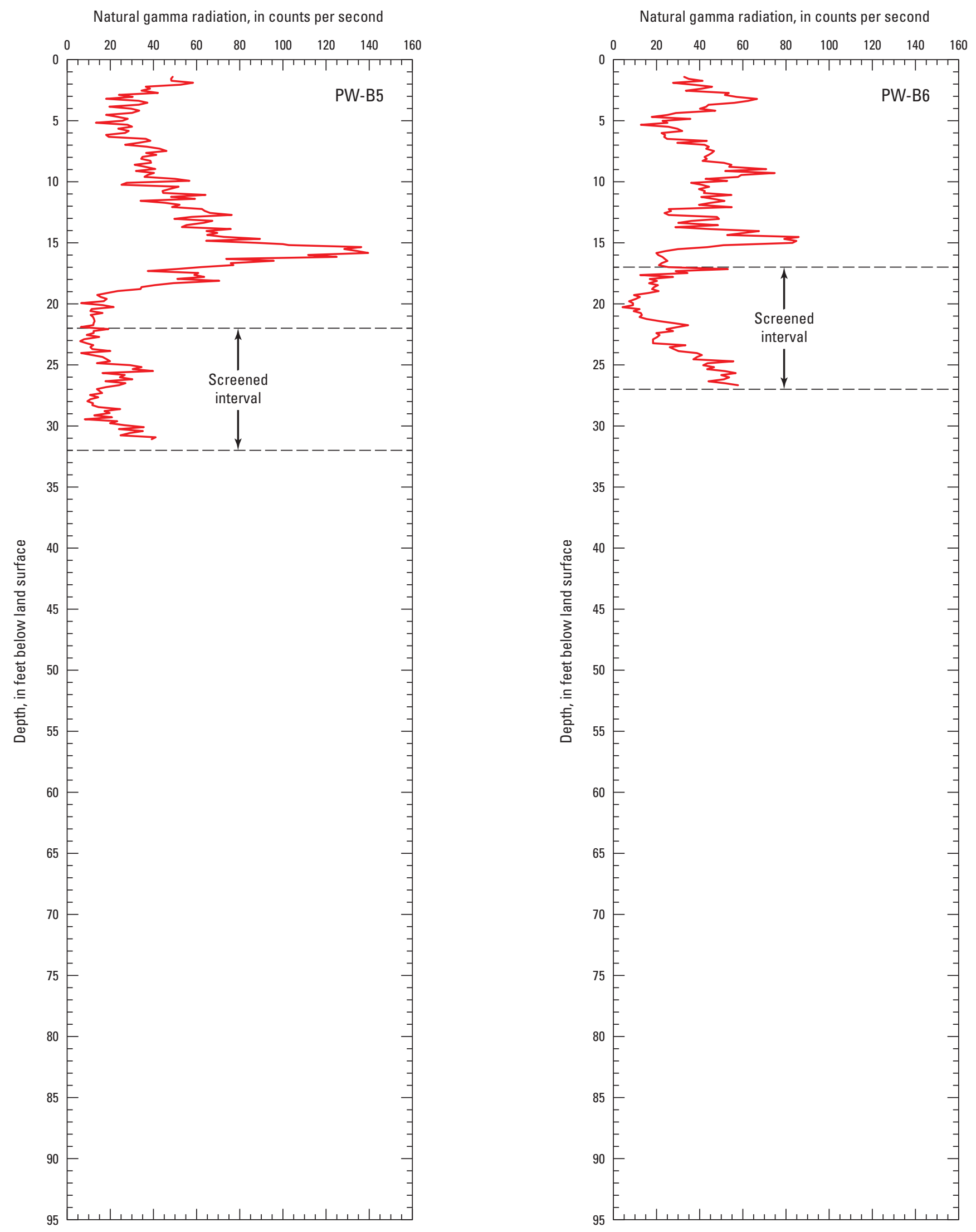

Figure 2-1. Natural gamma logs of wells at the Joint Base McGuire-Dix-Lakehurst Land Application Site and vicinity, New Jersey.-Continued 

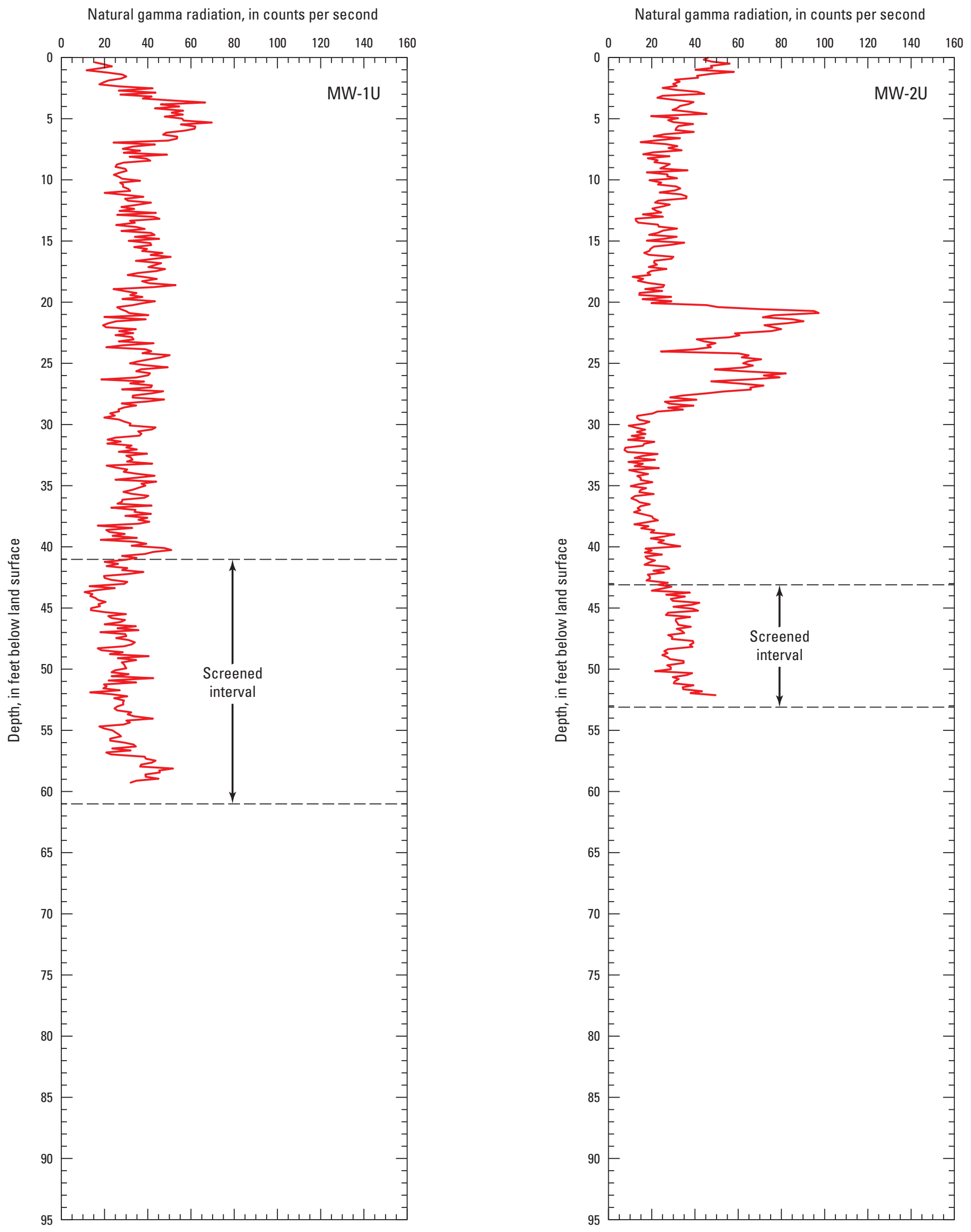

Figure 2-1. Natural gamma logs of wells at the Joint Base McGuire-Dix-Lakehurst Land Application Site and vicinity, New Jersey.-Continued 
Natural gamma radiation, in counts per second

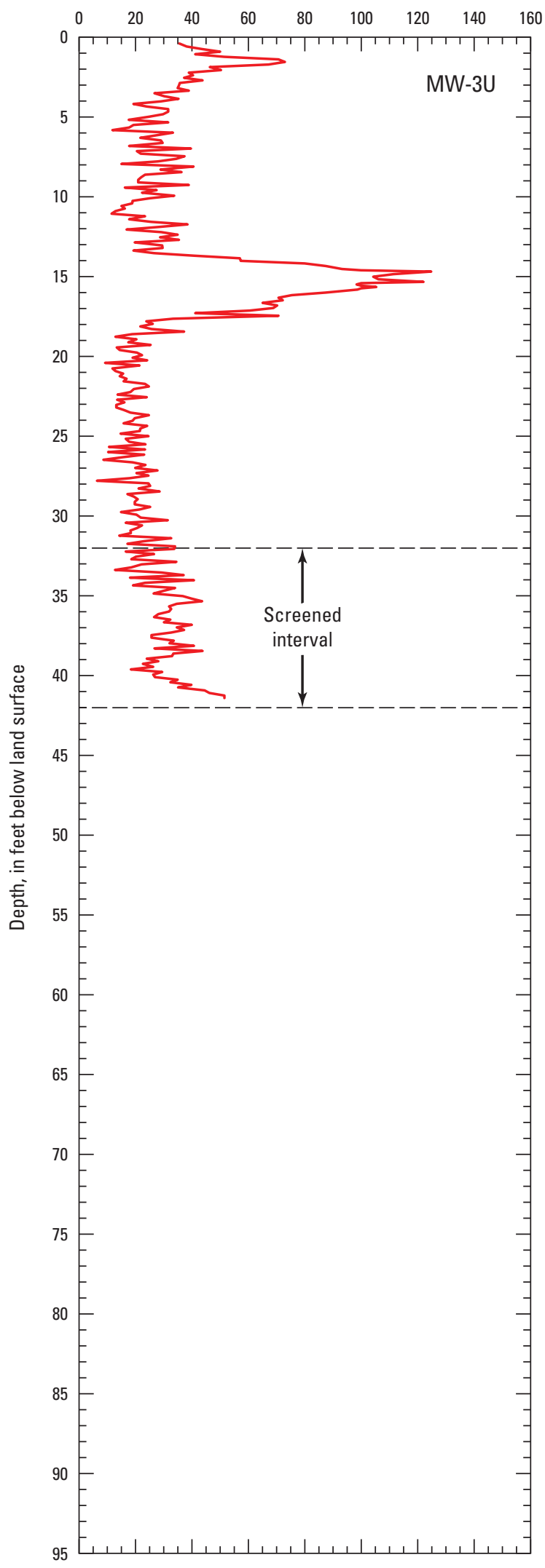

Natural gamma radiation, in counts per second

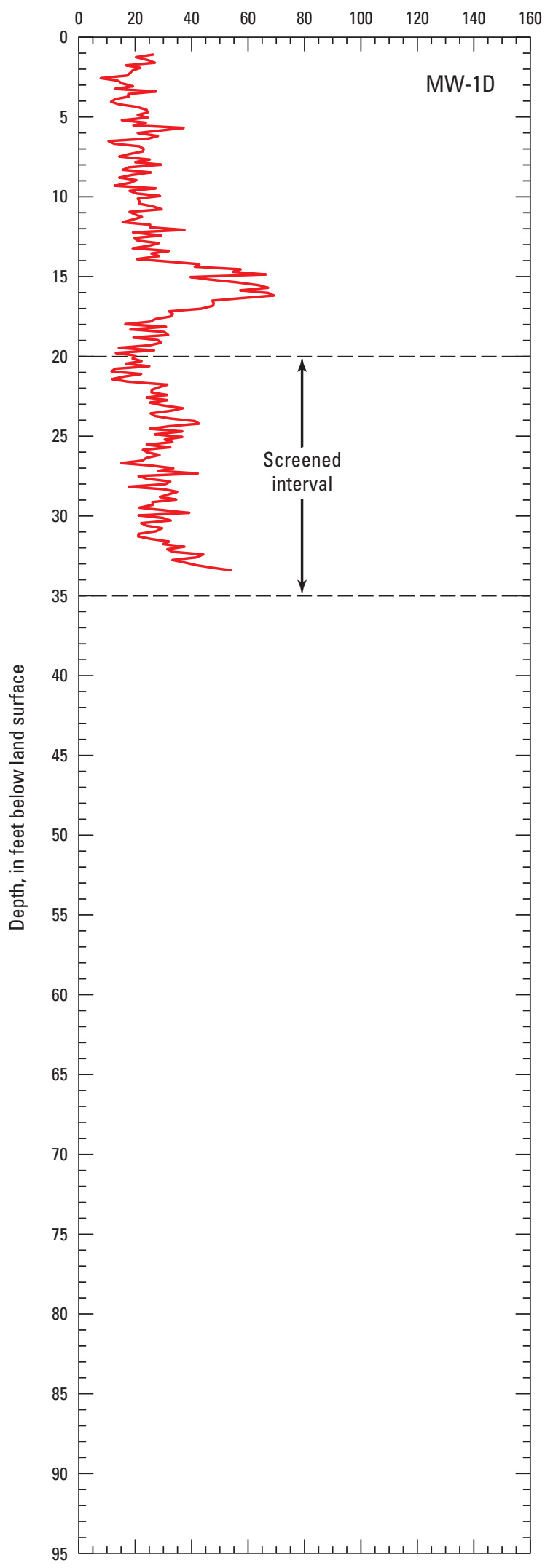

Figure 2-1. Natural gamma logs of wells at the Joint Base McGuire-Dix-Lakehurst Land Application Site and vicinity, New Jersey.-Continued 

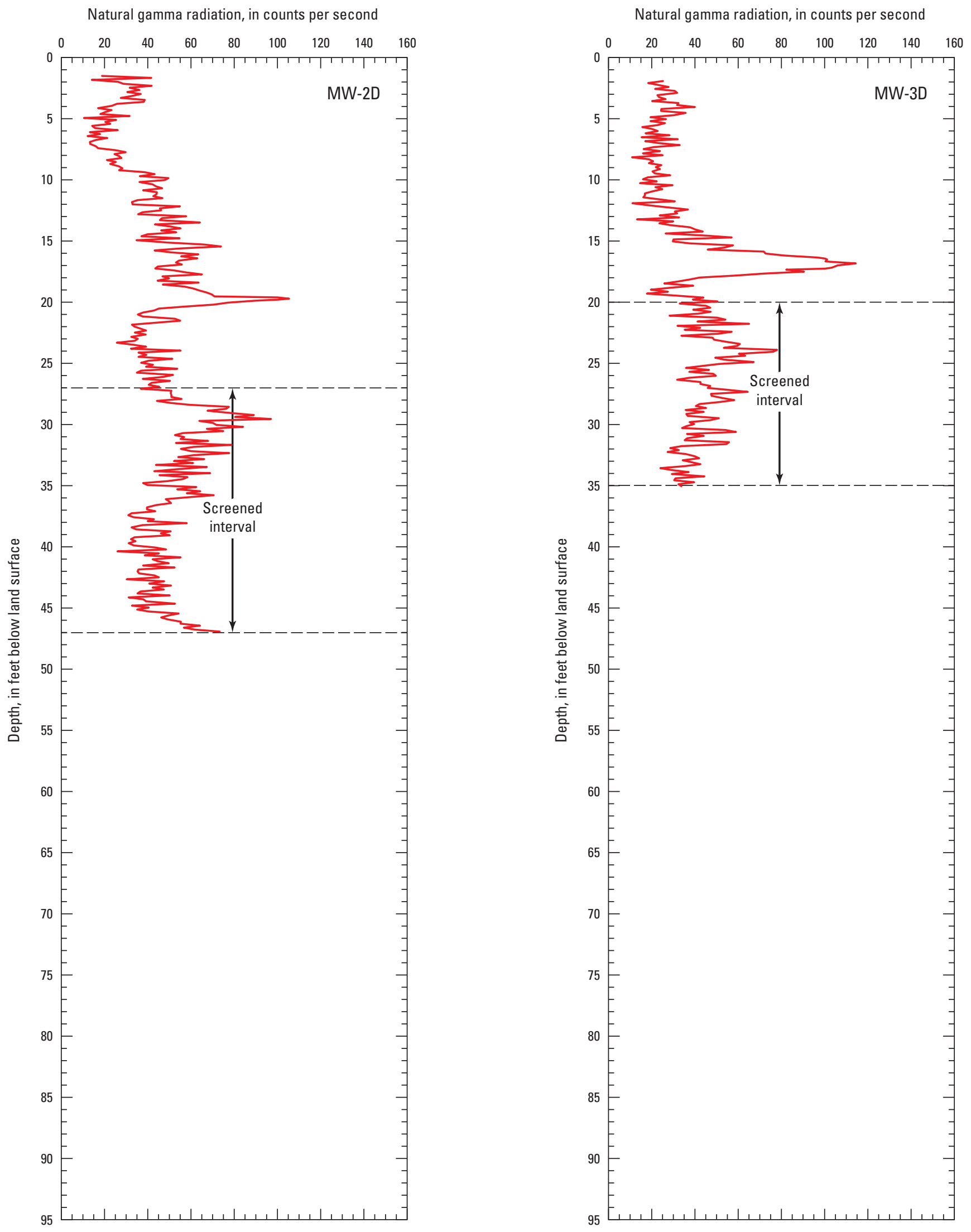

Figure 2-1. Natural gamma logs of wells at the Joint Base McGuire-Dix-Lakehurst Land Application Site and vicinity, New Jersey.-Continued 
Natural gamma radiation, in counts per second

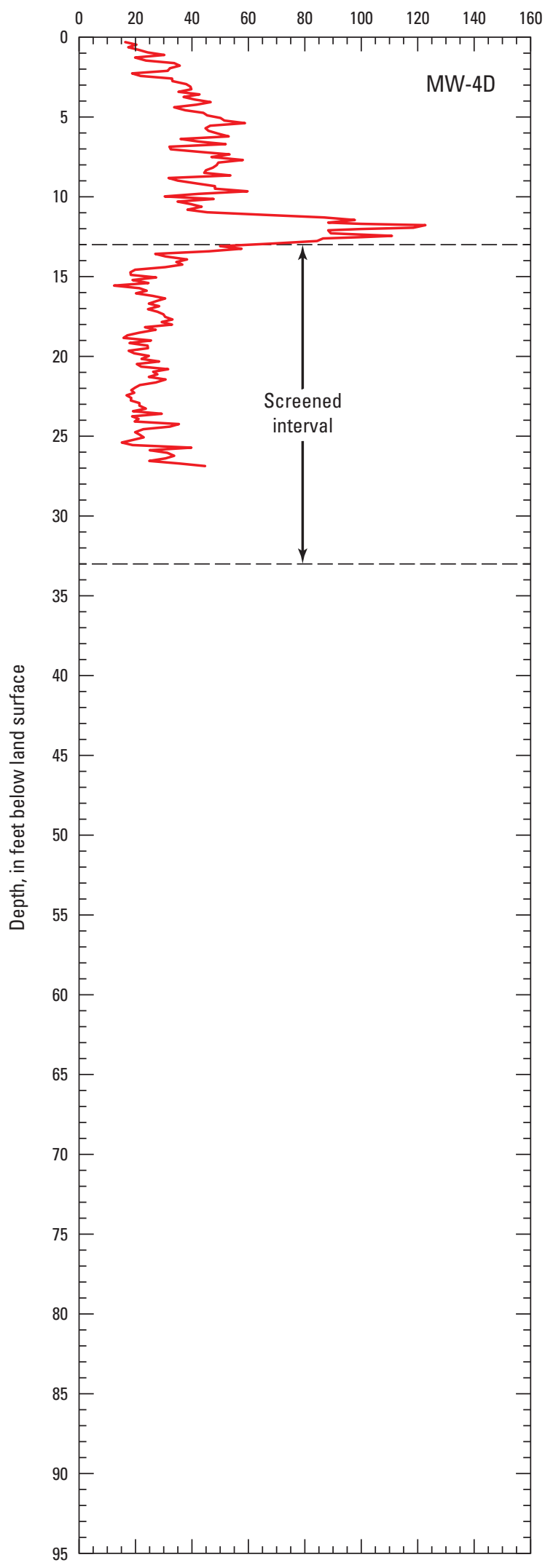

Natural gamma radiation, in counts per second

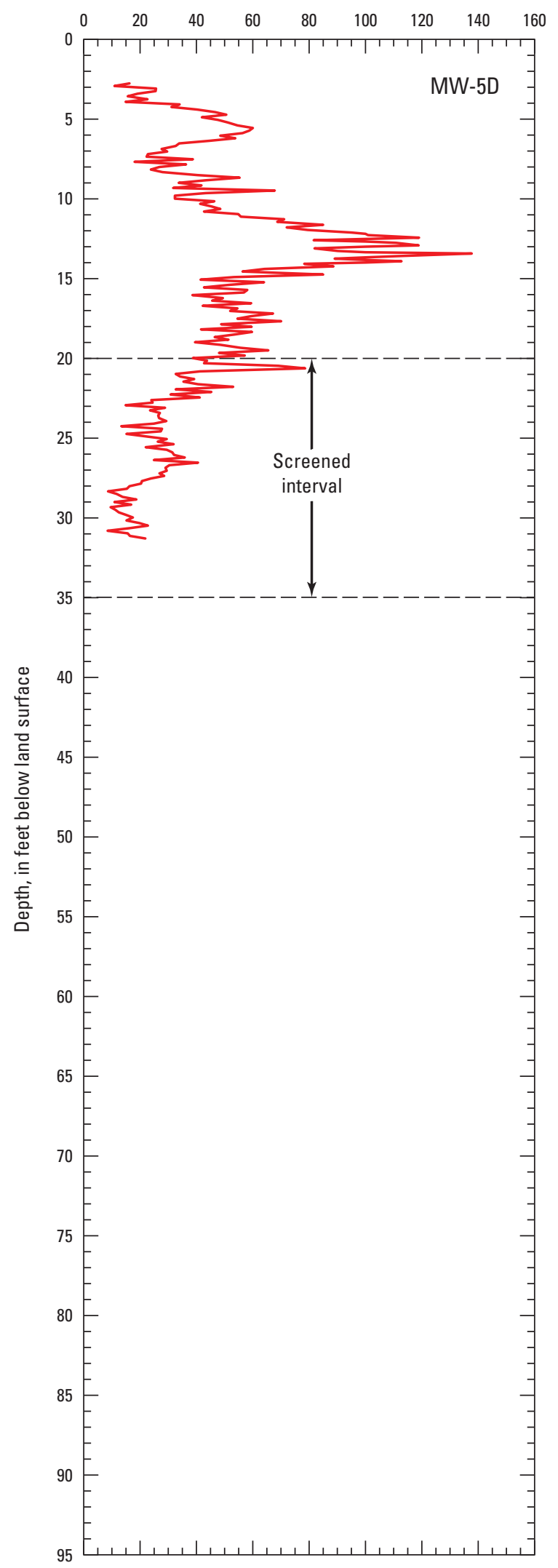

Figure 2-1. Natural gamma logs of wells at the Joint Base McGuire-Dix-Lakehurst Land Application Site and vicinity, New Jersey.-Continued 

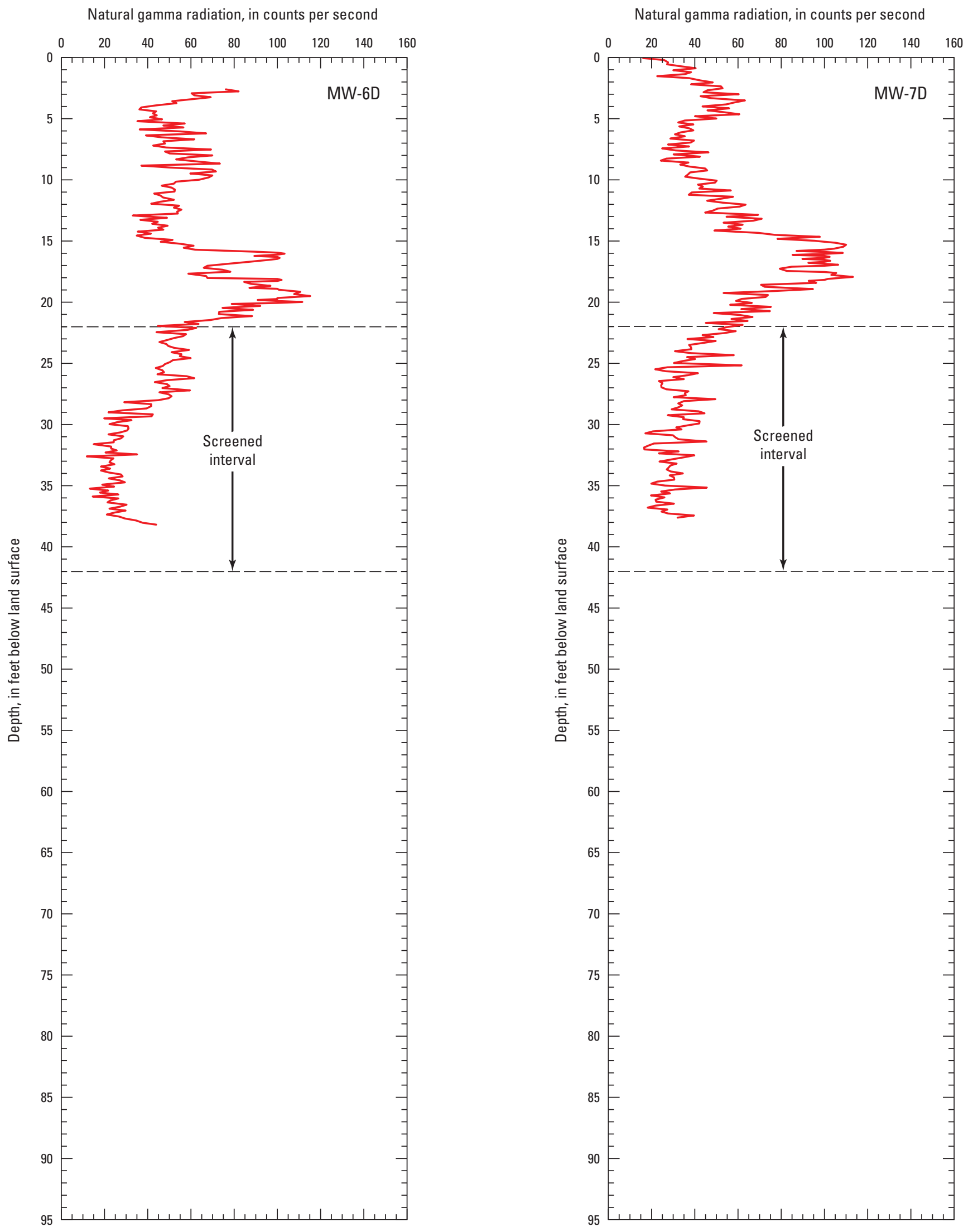

Figure 2-1. Natural gamma logs of wells at the Joint Base McGuire-Dix-Lakehurst Land Application Site and vicinity, New Jersey.-Continued 

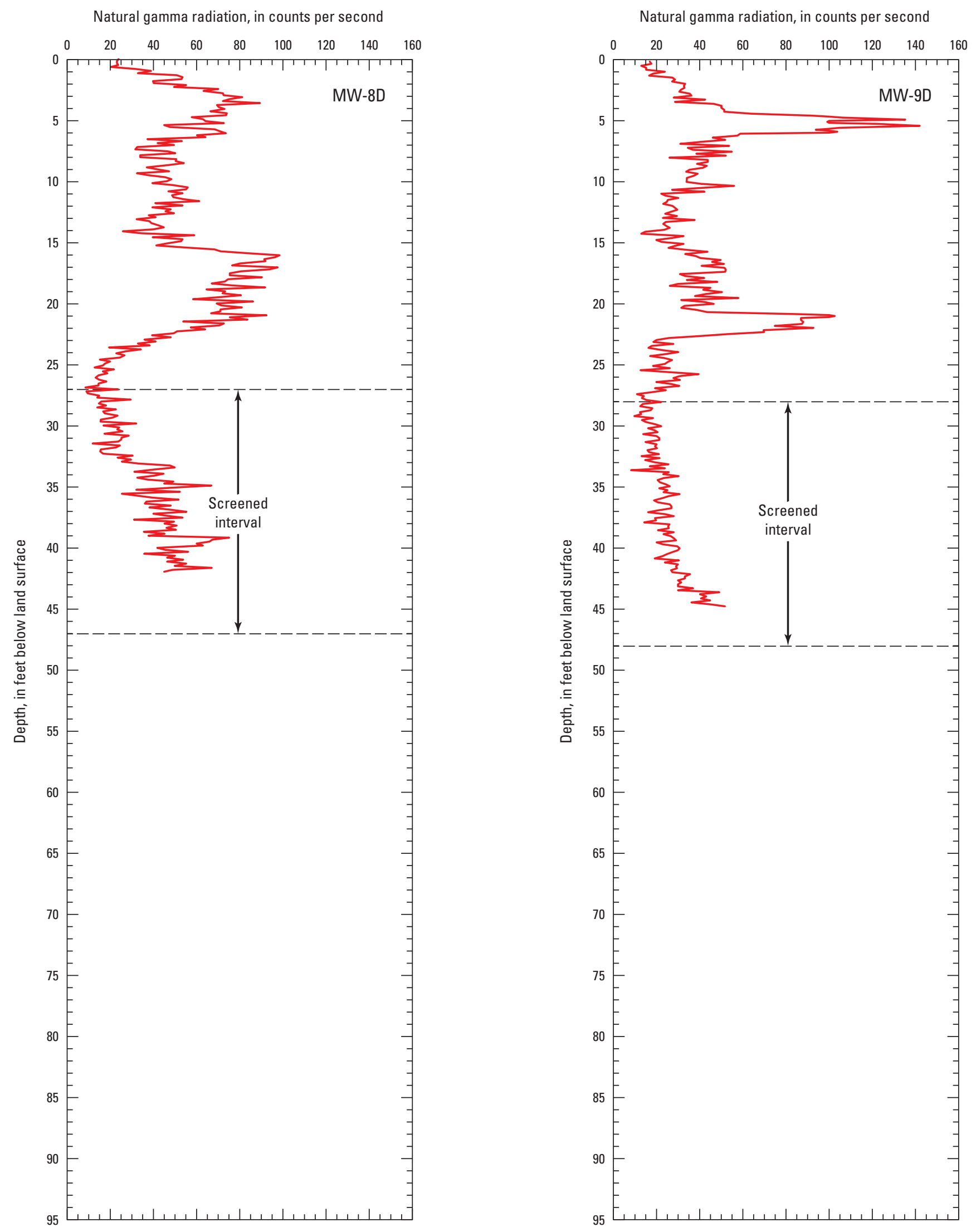

Figure 2-1. Natural gamma logs of wells at the Joint Base McGuire-Dix-Lakehurst Land Application Site and vicinity, New Jersey.-Continued 

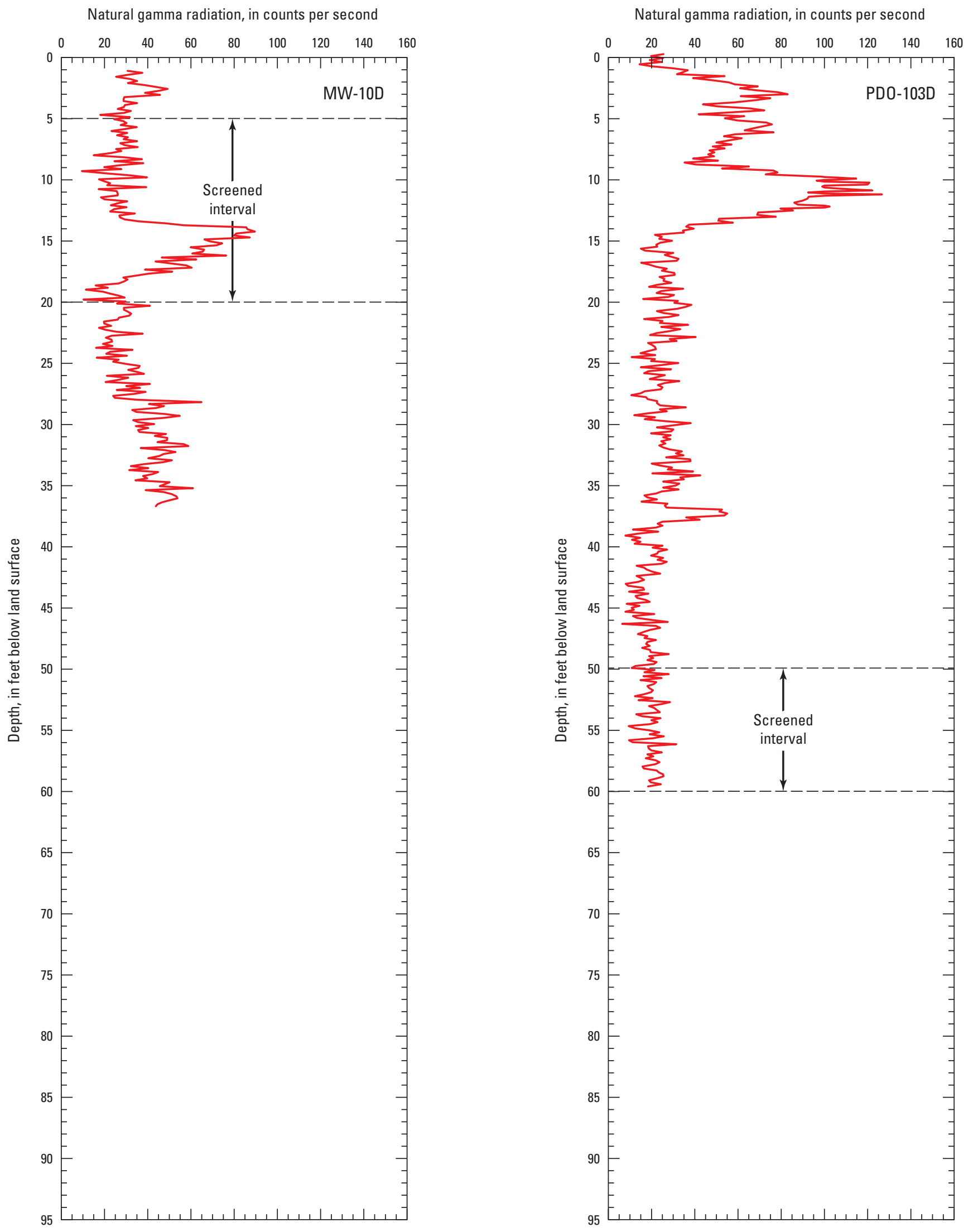

Figure 2-1. Natural gamma logs of wells at the Joint Base McGuire-Dix-Lakehurst Land Application Site and vicinity, New Jersey.-Continued 

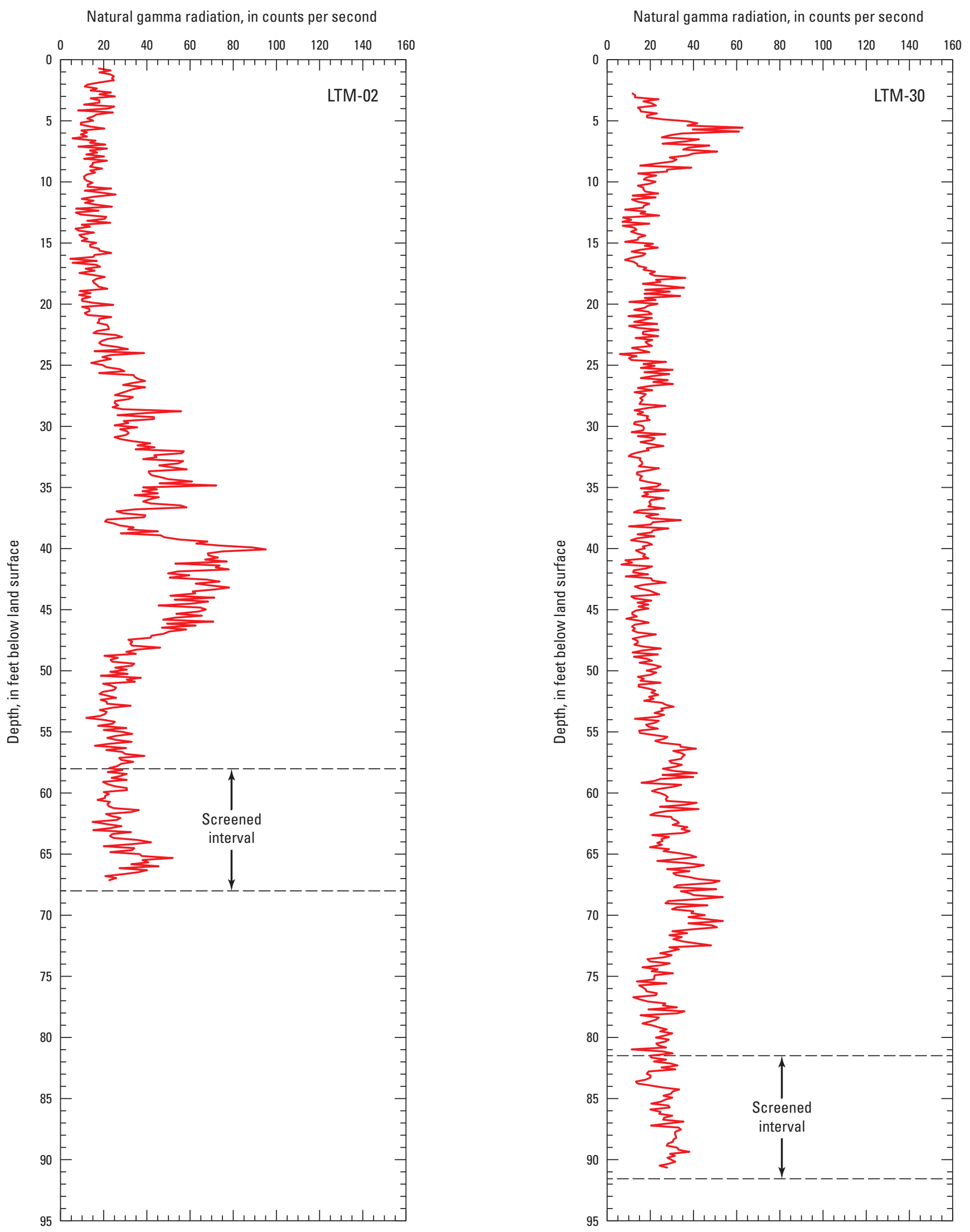

Figure 2-1. Natural gamma logs of wells at the Joint Base McGuire-Dix-Lakehurst Land Application Site and vicinity, New Jersey.-Continued 


\section{Appendix 3}

Table of well construction and driller log descriptions from wells at the Joint Base McGuire-DixLakehurst Land Application Site and vicinity, New Jersey. 


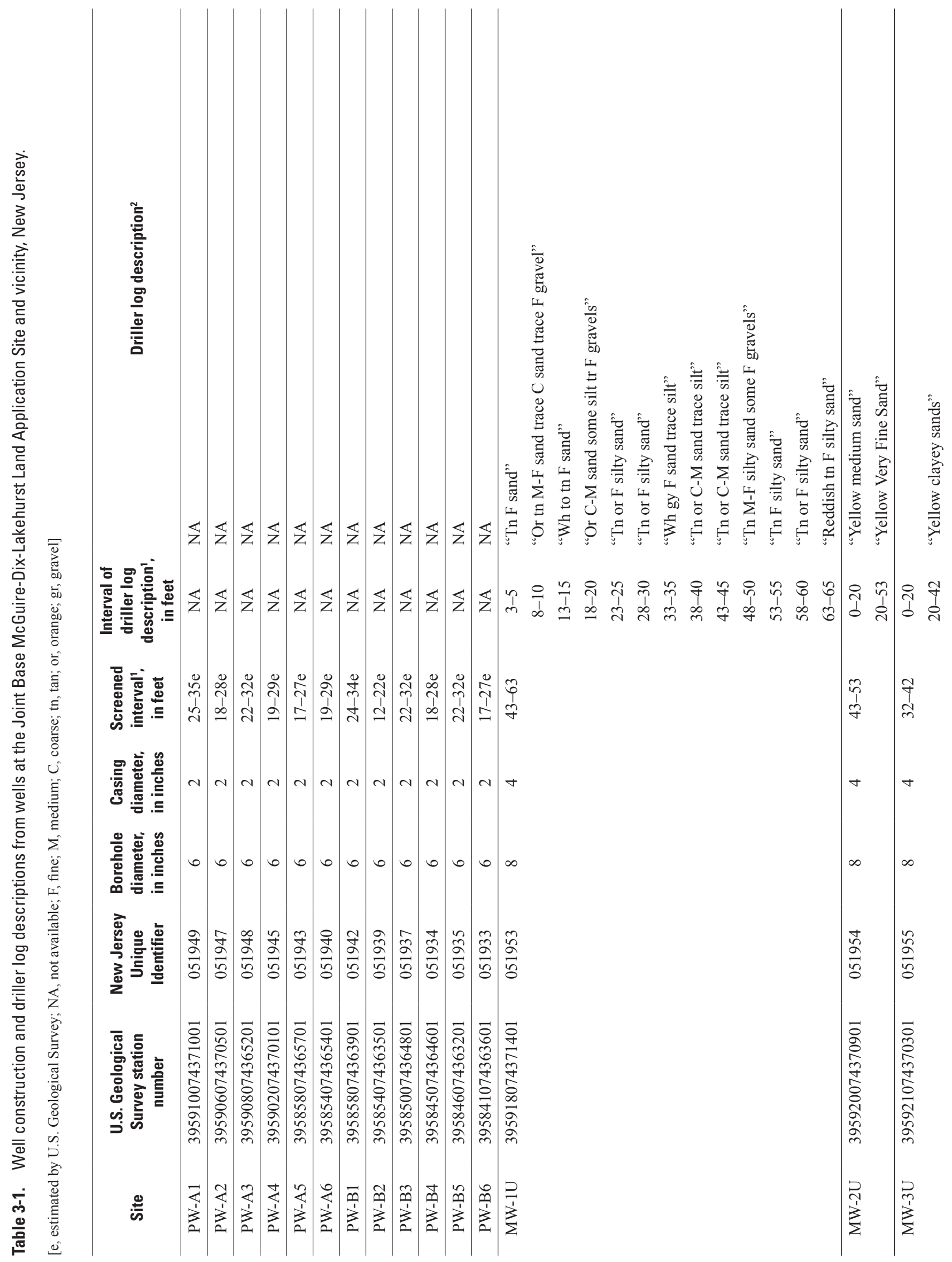




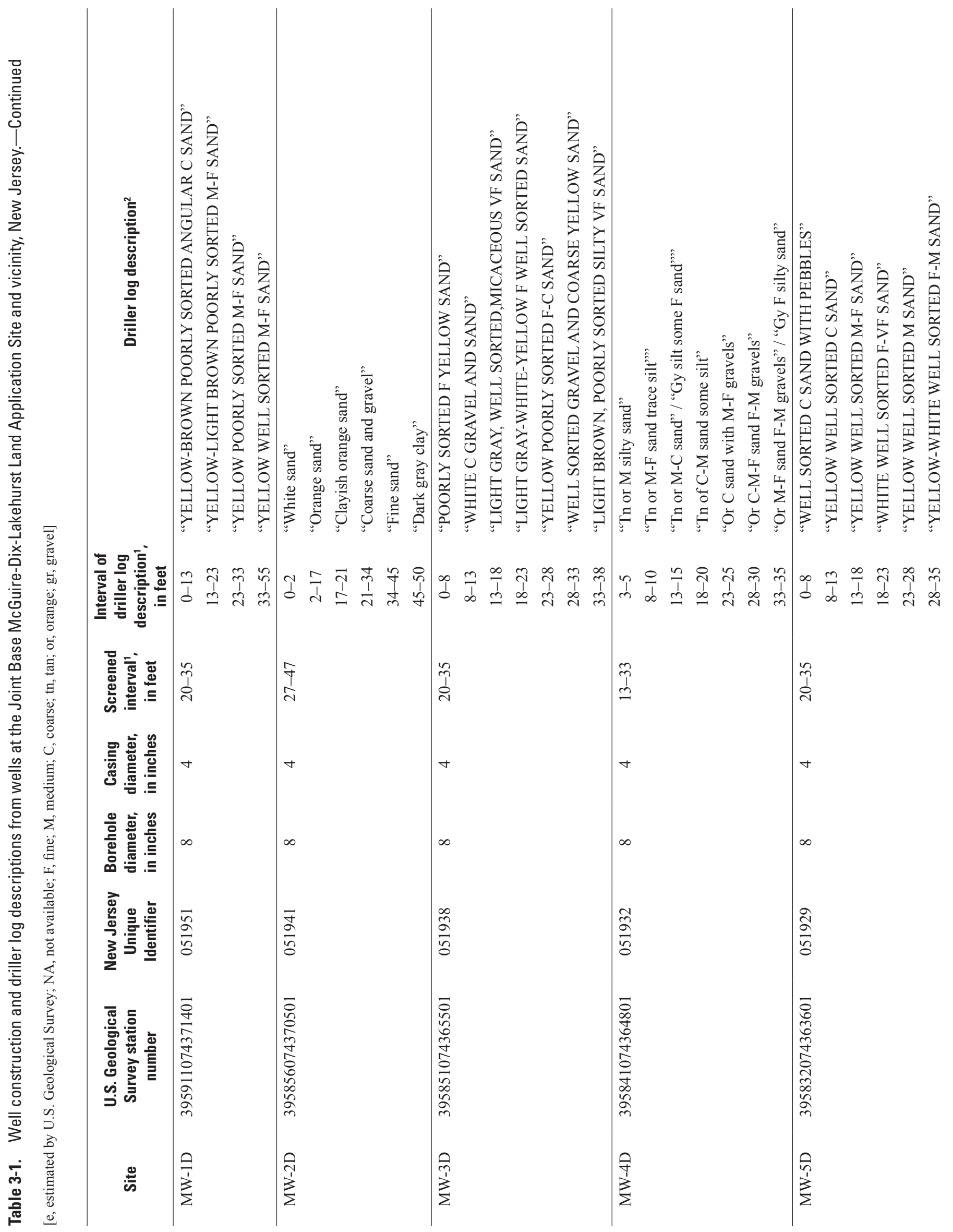




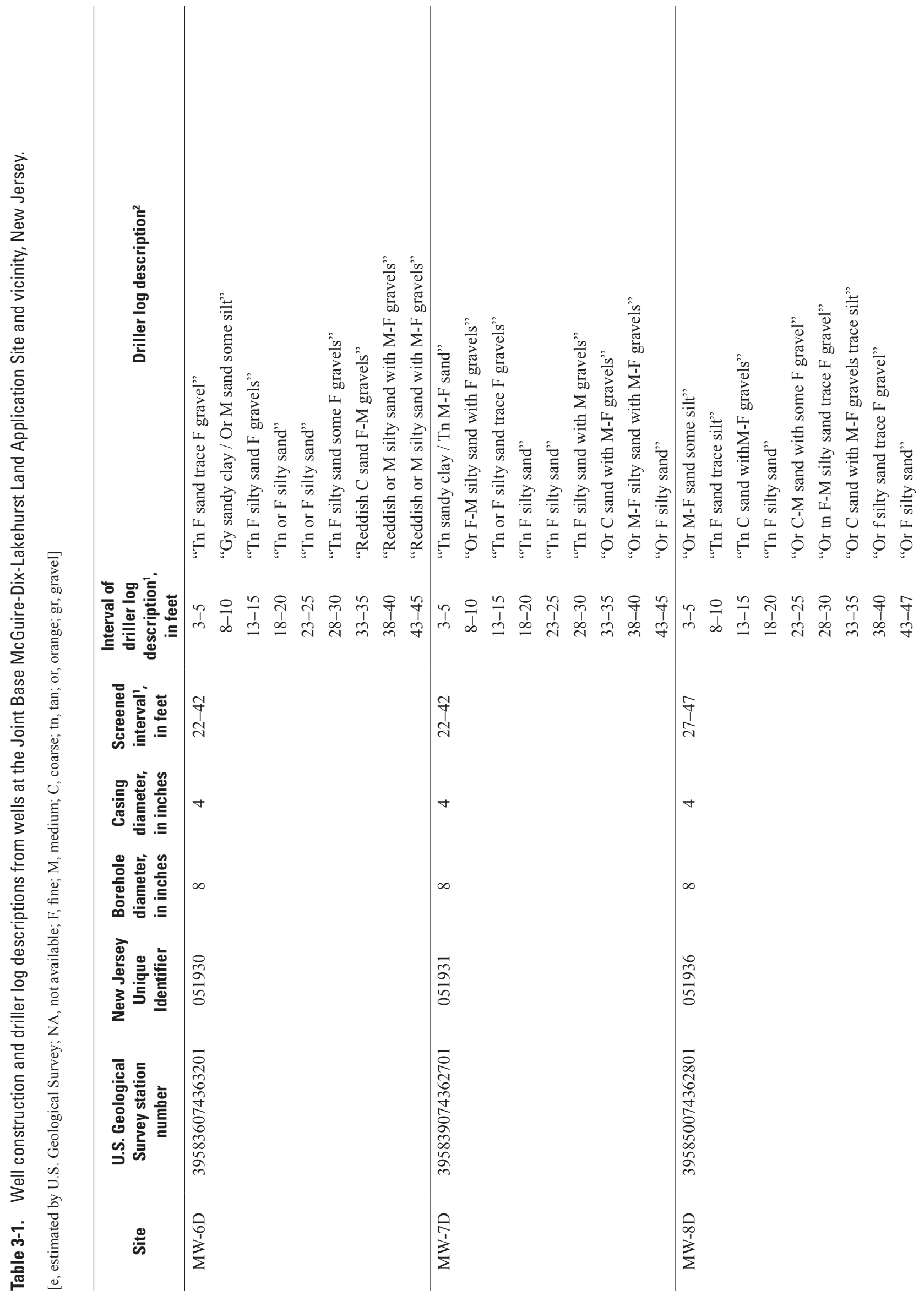




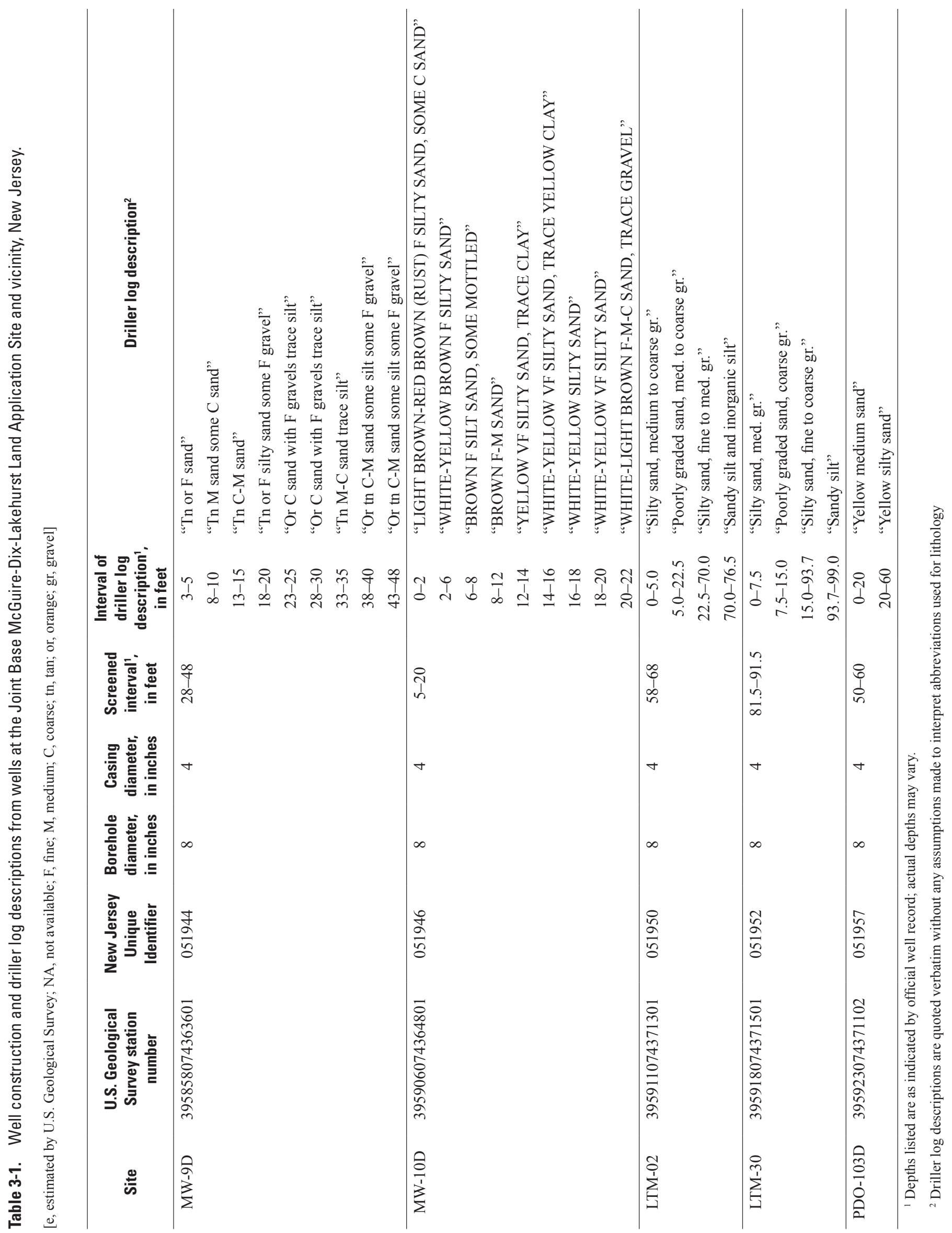




\section{Appendix 4}

Normalized water-level displacement as a function of time during slug tests of piezometer wells at the Joint Base McGuire-Dix-Lakehurst Land Application Site, New Jersey, using Bouwer and Rice (1976) solution. 

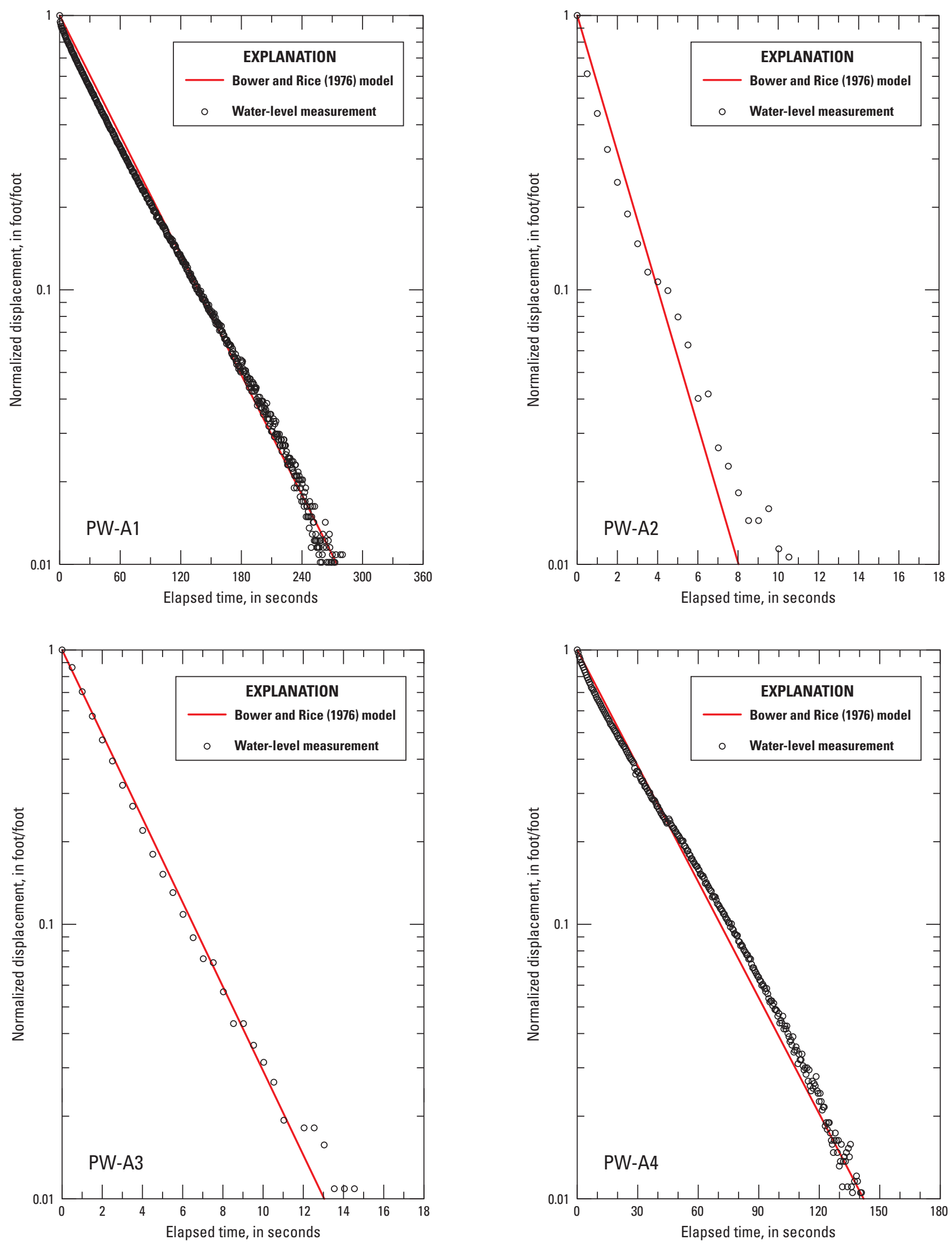

Figure 4-1. Normalized water-level displacement as a function of time during slug tests of piezometer wells at the Joint Base McGuireDix-Lakehurst Land Application Site, New Jersey, using Bouwer and Rice (1976) solution. 

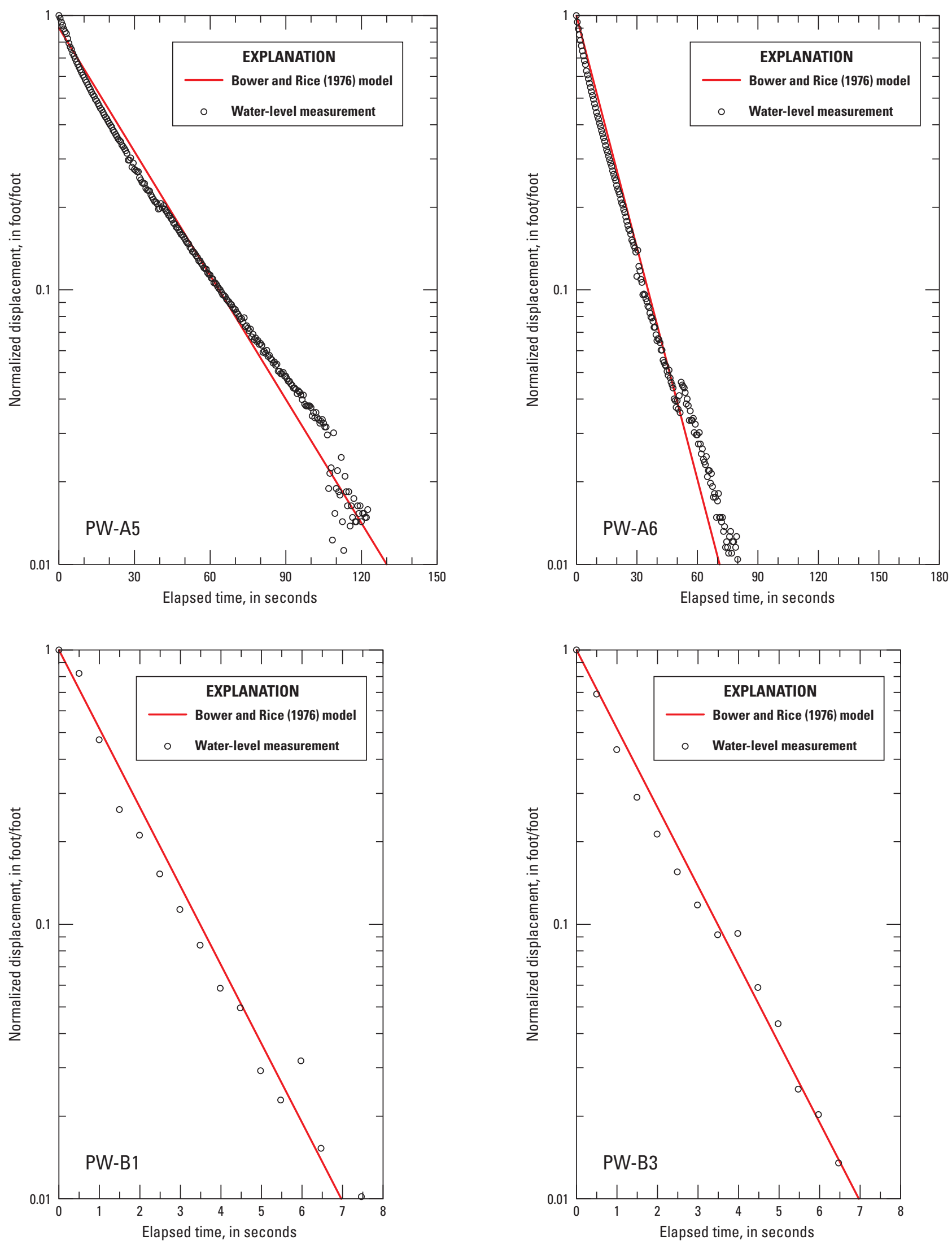

Figure 4-1. Normalized water-level displacement as a function of time during slug tests of piezometer wells at the Joint Base McGuireDix-Lakehurst Land Application Site, New Jersey, using Bouwer and Rice (1976) solution.-Continued 

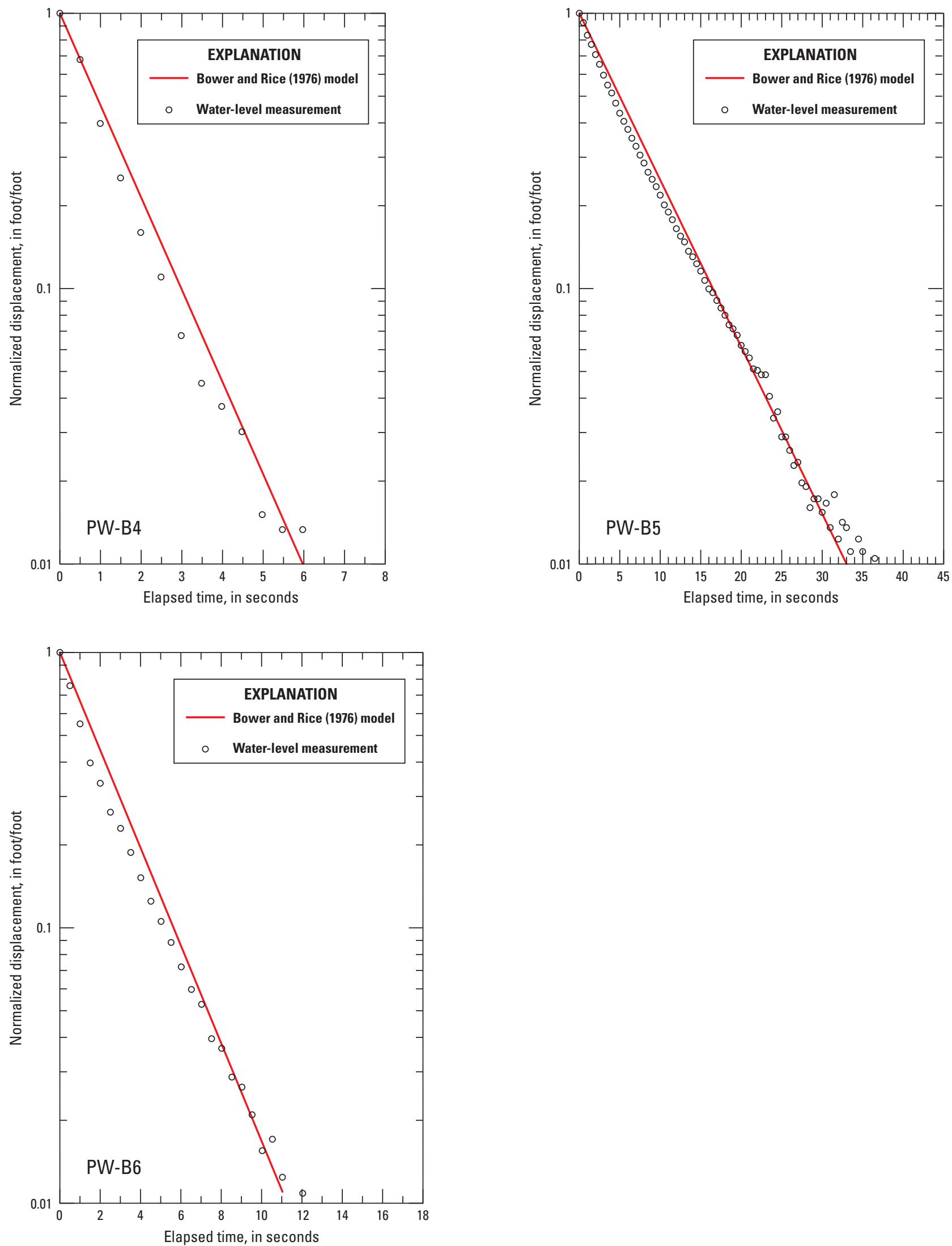

Figure 4-1. Normalized water-level displacement as a function of time during slug tests of piezometer wells at the Joint Base McGuireDix-Lakehurst Land Application Site, New Jersey, using Bouwer and Rice (1976) solution._Continued 


\section{Appendix 5}

Table of discrete water-level altitudes in piezometer wells at the Joint Base McGuire-

Dix-Lakehurst Land Application Site, New Jersey, as measured by site operators from January 2000-December 2014. 


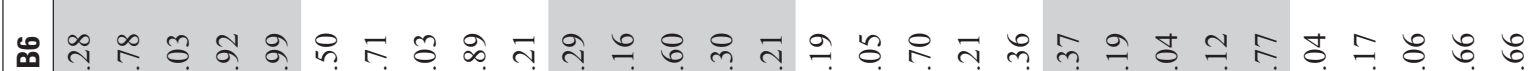
ja

以

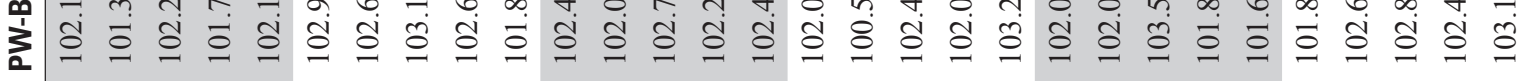

य ป ๆ

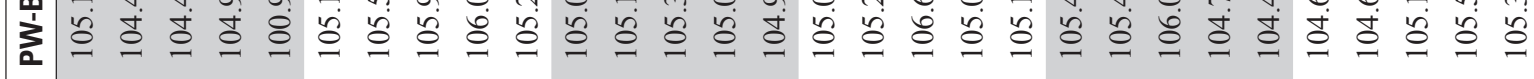

m

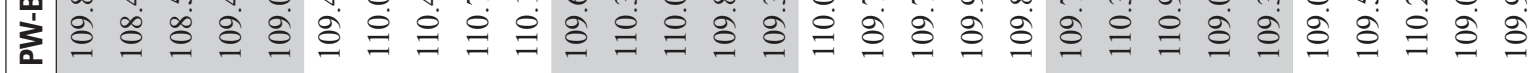

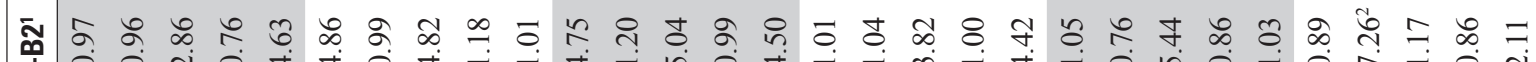

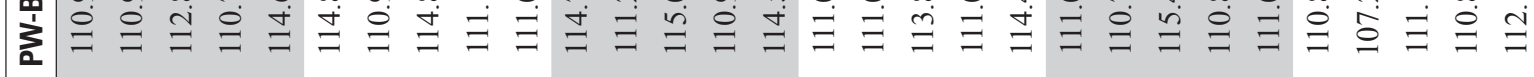

- ๆ

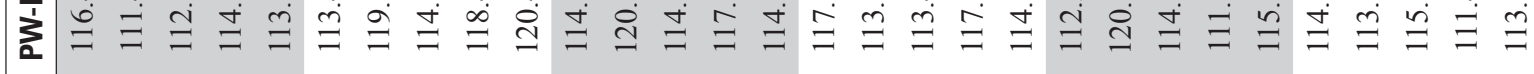

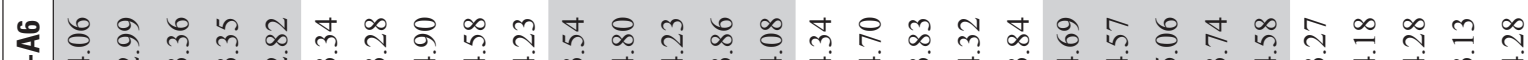

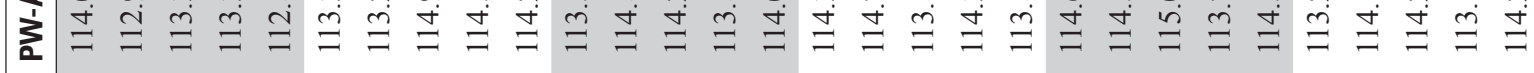

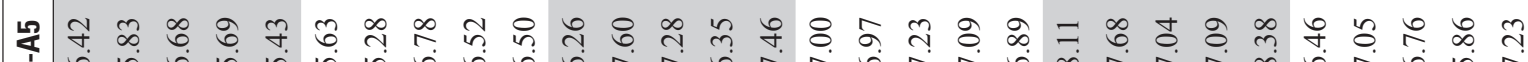

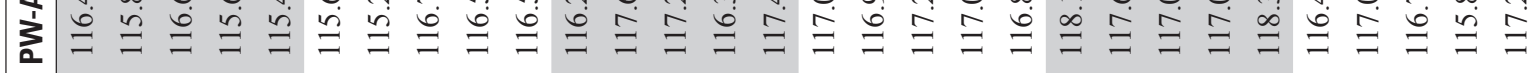

स

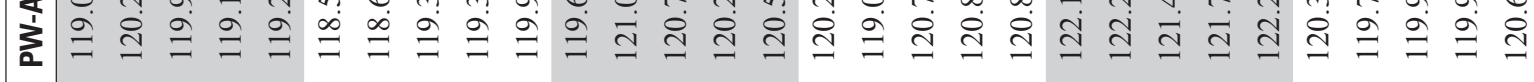

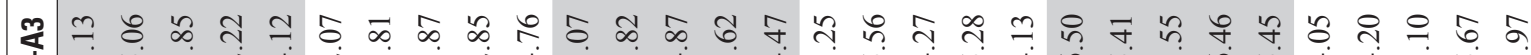
尚

భै का

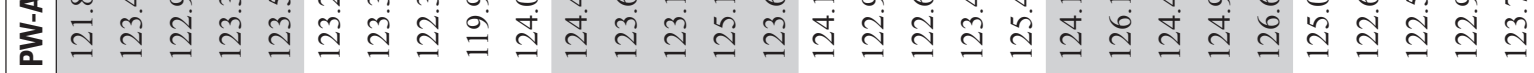

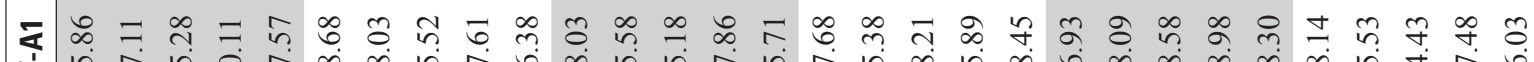
文光

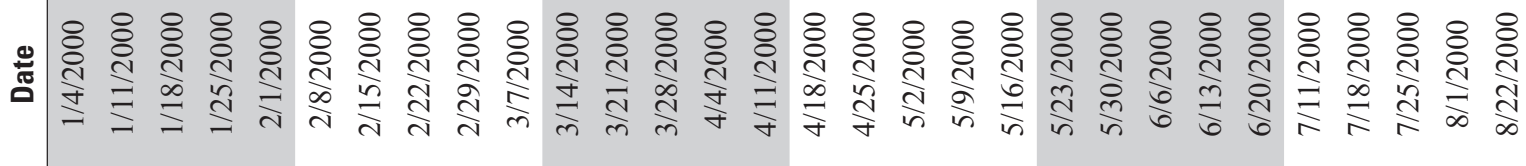




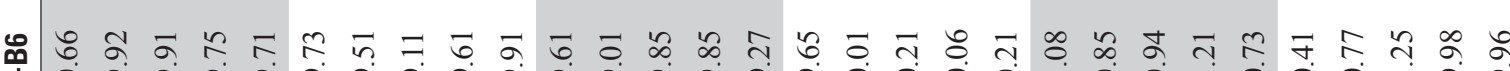
3

L मू

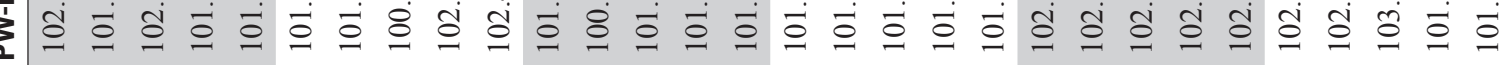

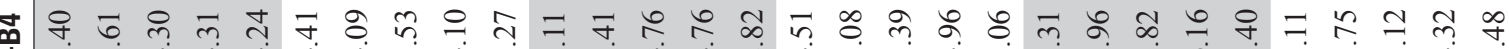

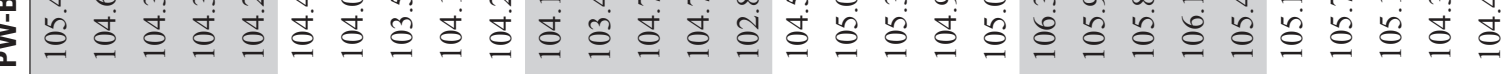

๓

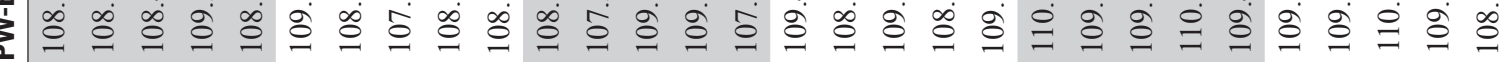

ఫై

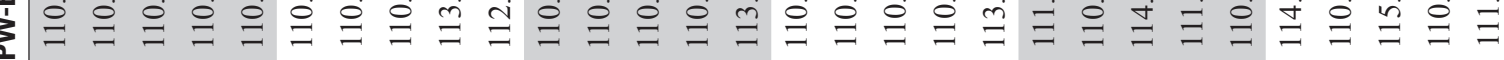

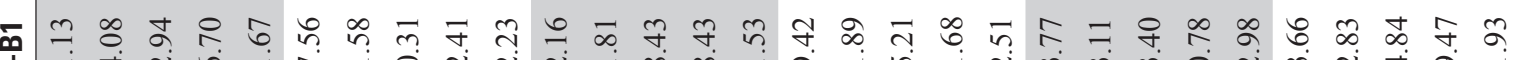

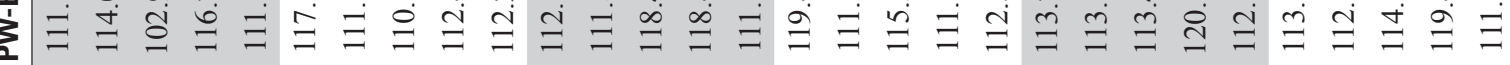

눈

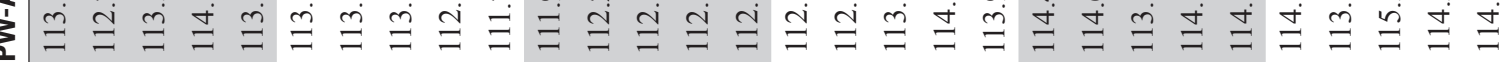

\&ุ⿱

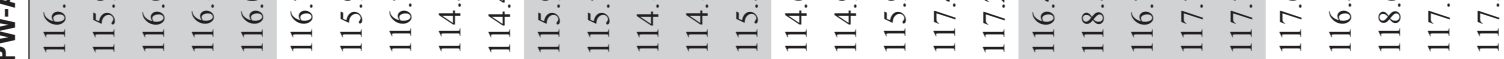

से

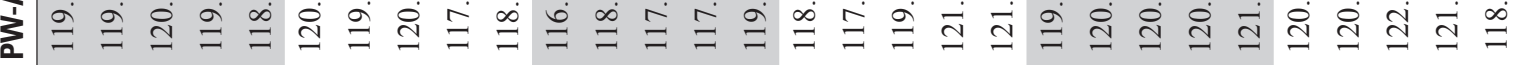

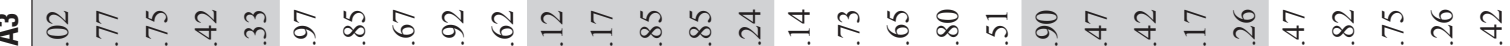

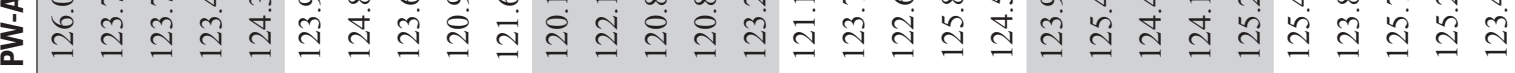

ఇै $\cong$ f 光至

₹

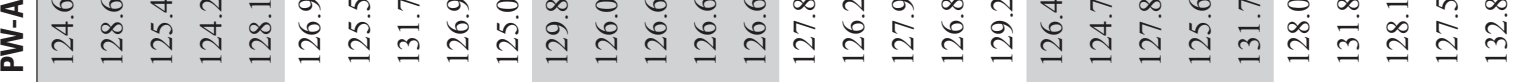

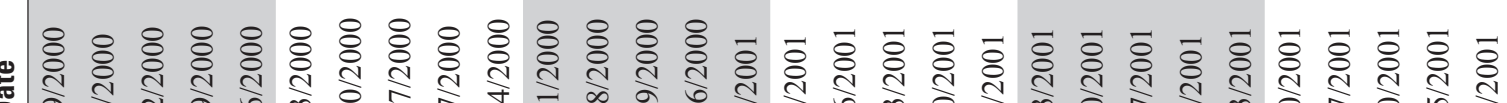

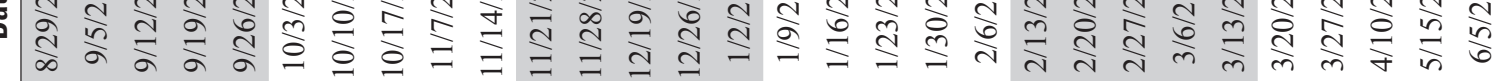




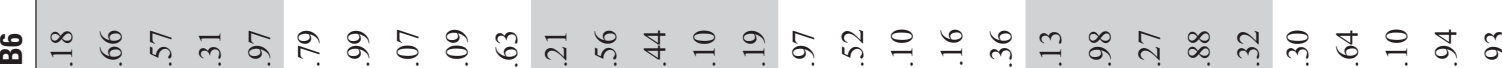

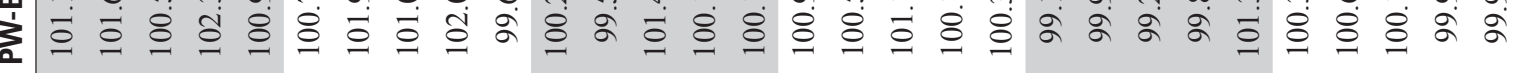

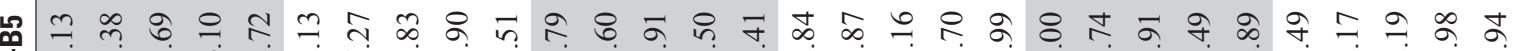
jô

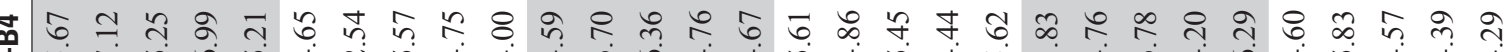

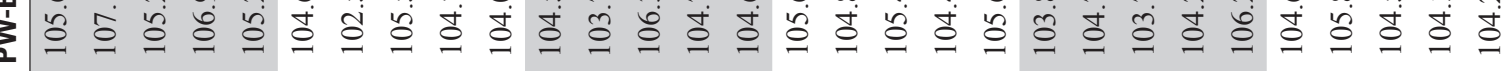

m

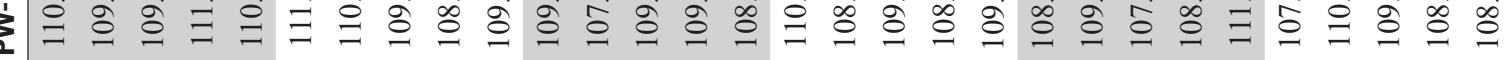

ฟิ)

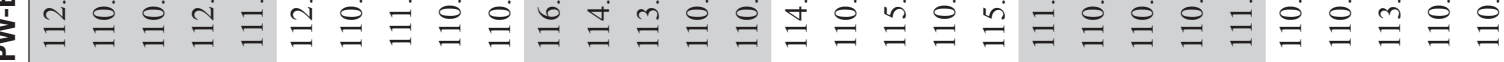

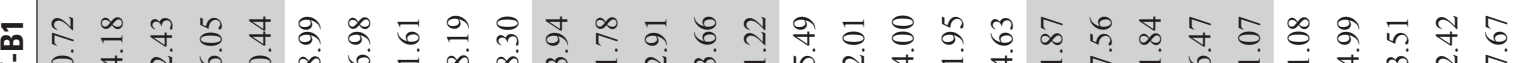

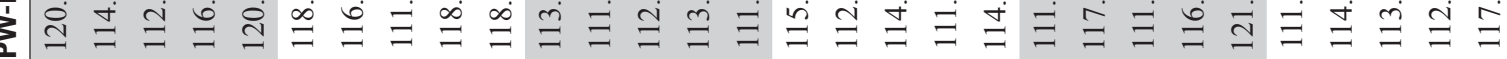

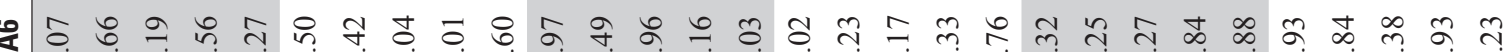

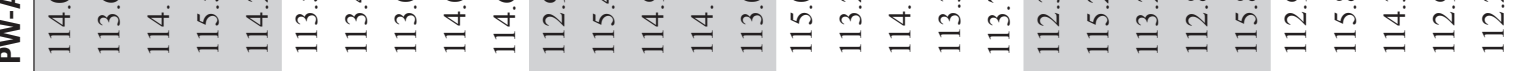

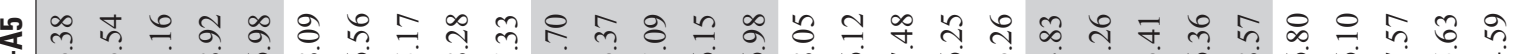

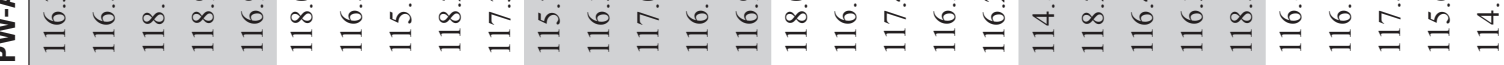

स 产

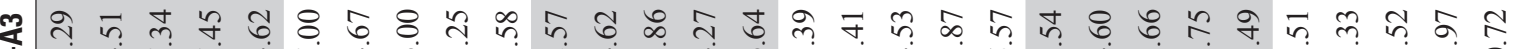

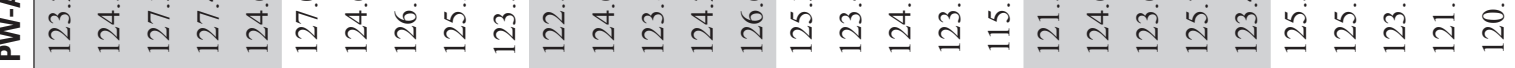

భै

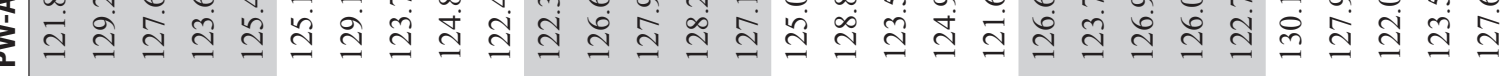

₹ भ

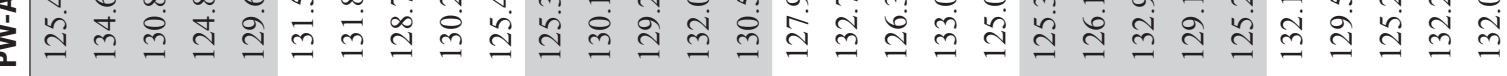

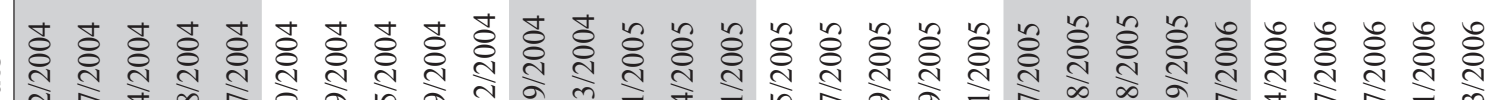

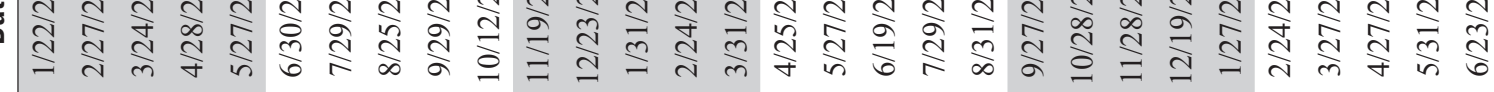


누 ३ె்

एᄋ 产

म jân

m خై

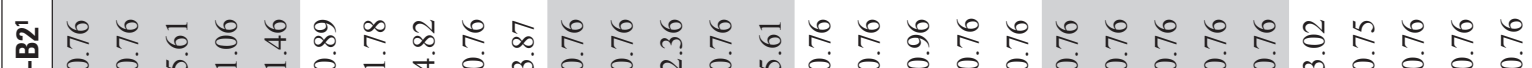

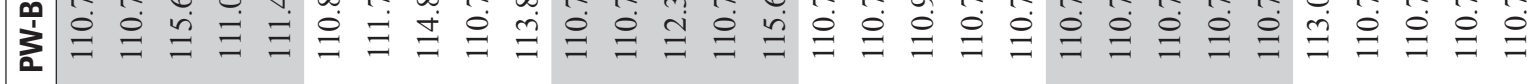

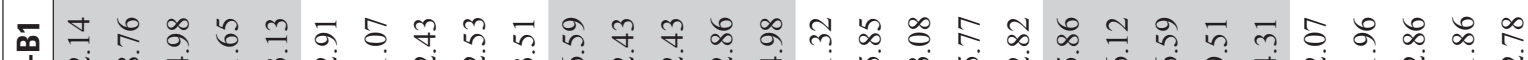

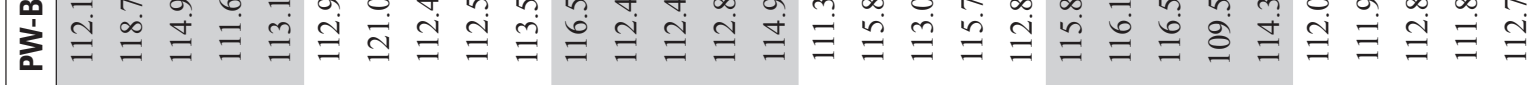

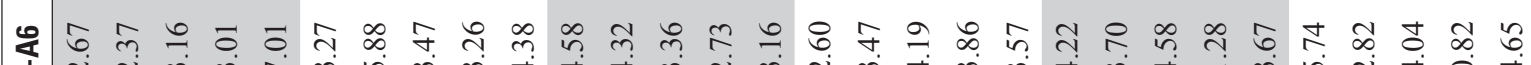

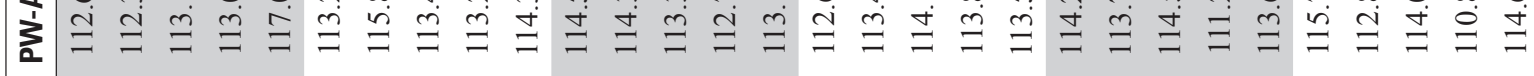

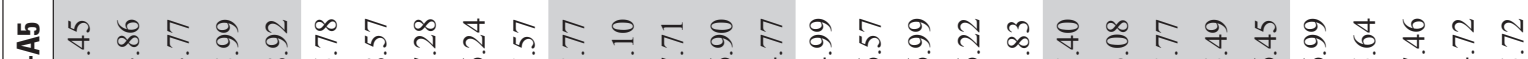

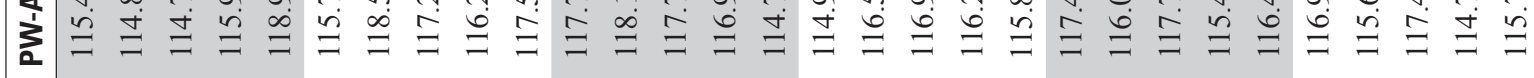

य운

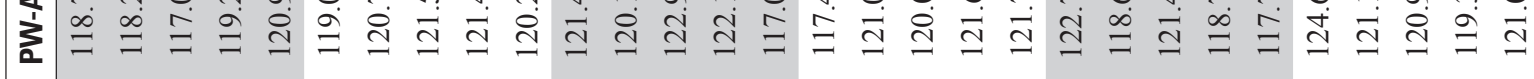

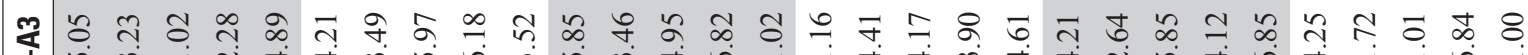
尚さ

₹ี $\bar{\tau}$ ก 范

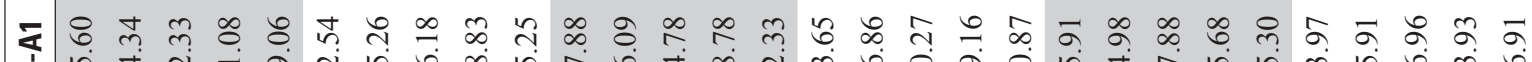

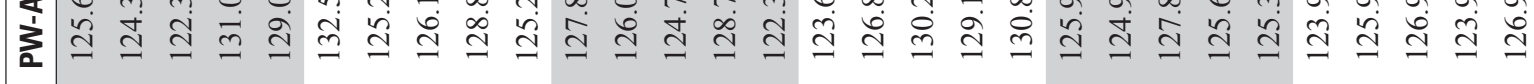

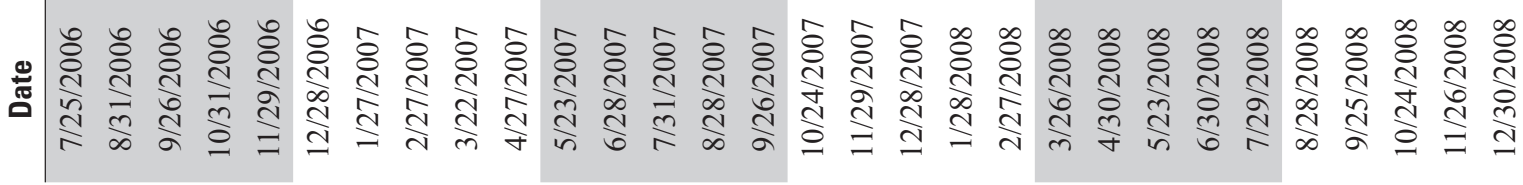


๓ 3ై

щ

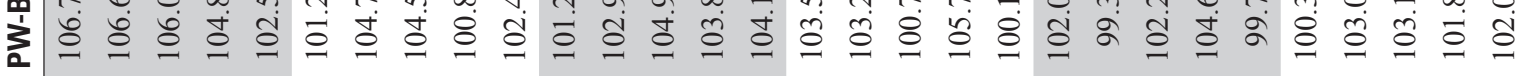

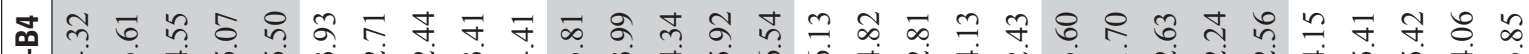

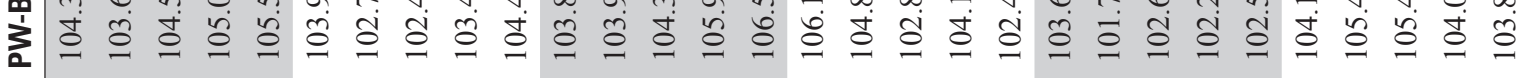

m

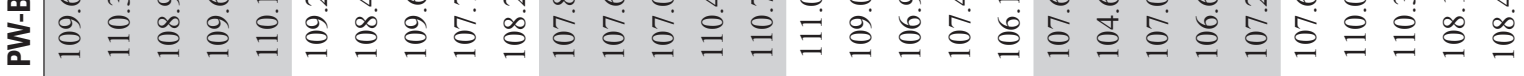

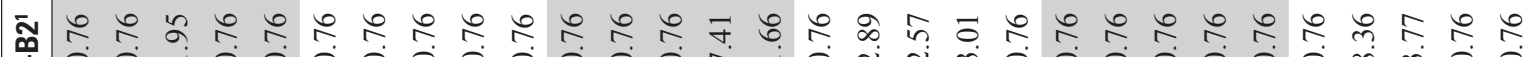

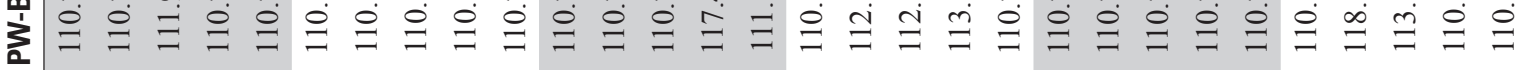

$\bar{m} \infty$ $\infty$

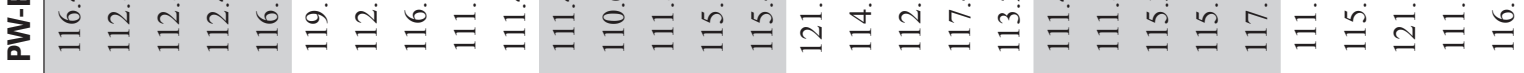

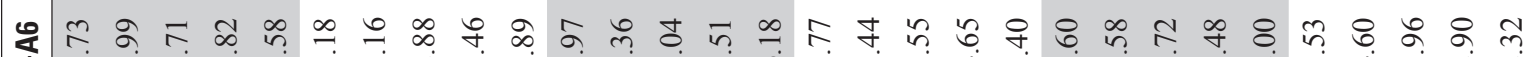

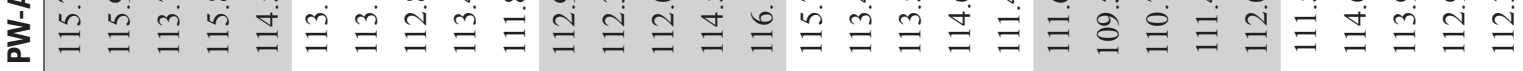

นา

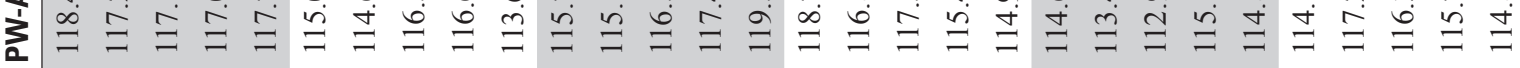

स 啇方

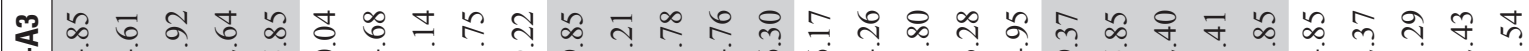

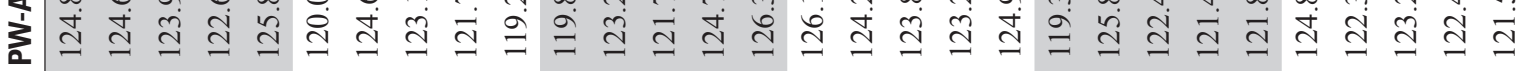

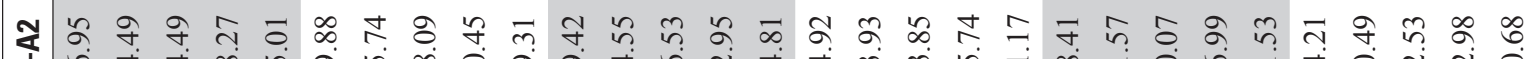

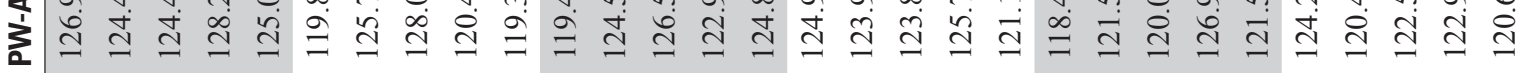

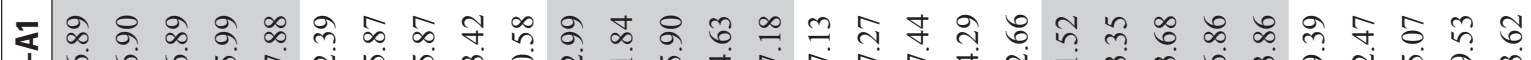
永

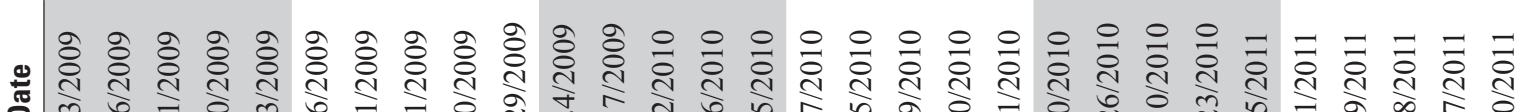

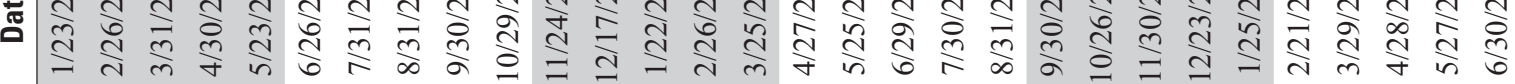


๓

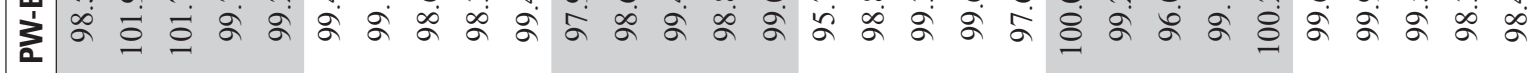

以 8 \&

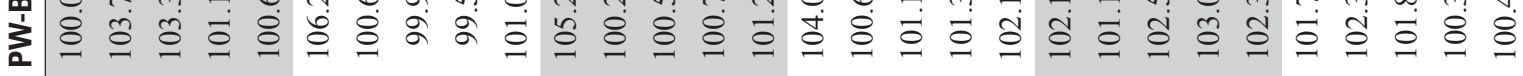

घ

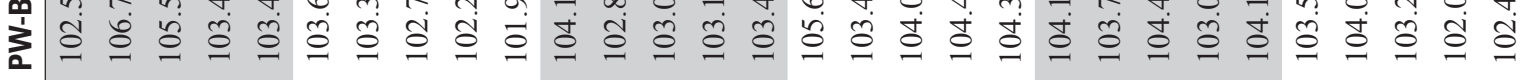

m

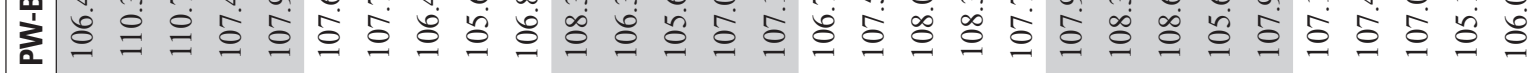

มี่

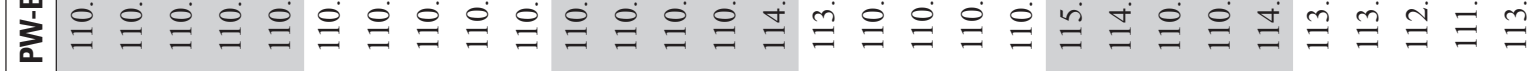

-

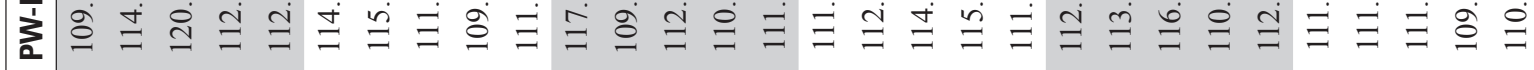

ঋ) กี

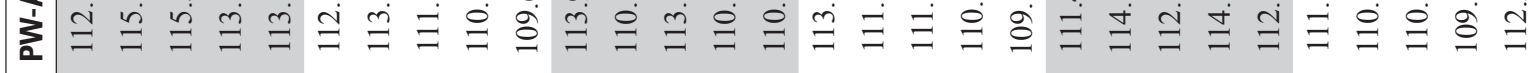

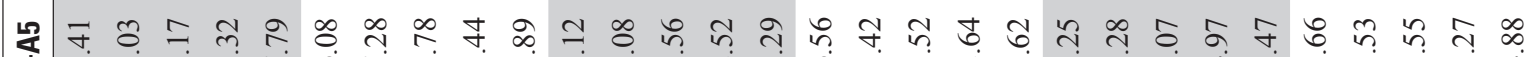

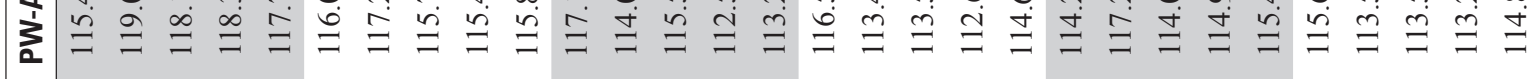

य

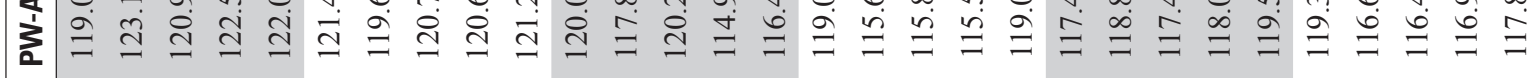

ఇ⿻

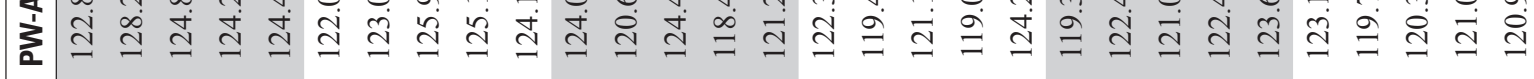

భน

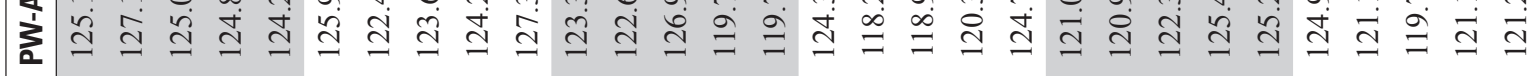

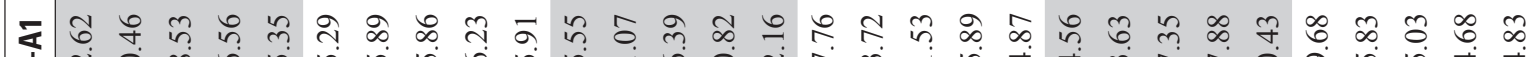
范

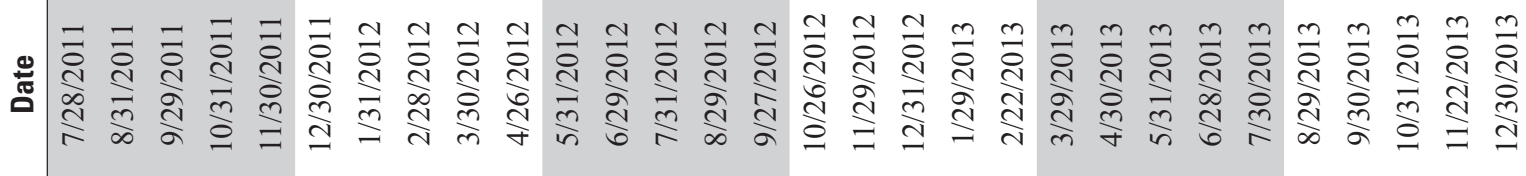



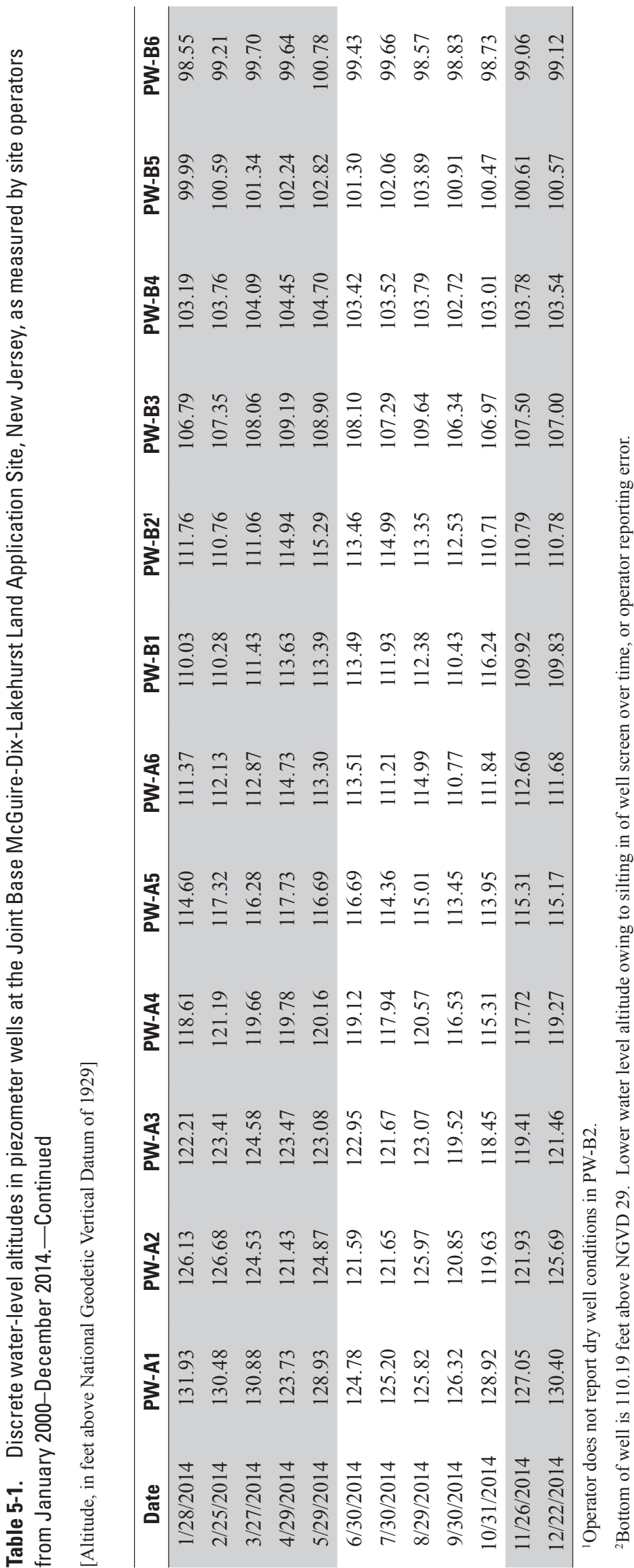


\section{Appendix 6}

Discrete water levels in piezometer wells at the Joint Base McGuire-Dix-Lakehurst

Land Application Site, New Jersey, as measured by site operators from January 2000-

December 2014. 

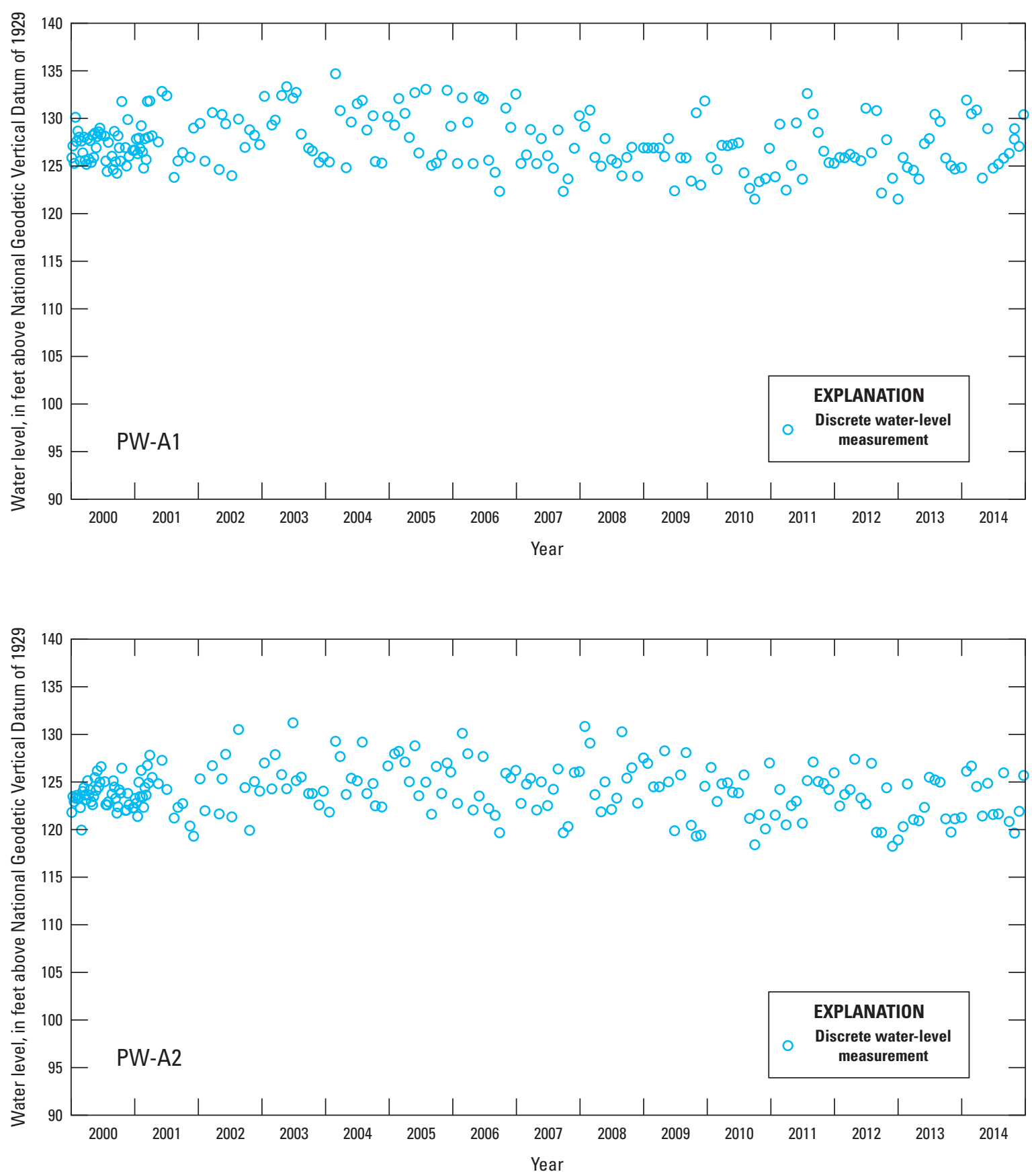

Figure 4-1. Discrete water levels in piezometer wells at the Joint Base McGuire-Dix-Lakehurst Land Application Site, New Jersey, as measured by site operators from January 2000-December 2014. 

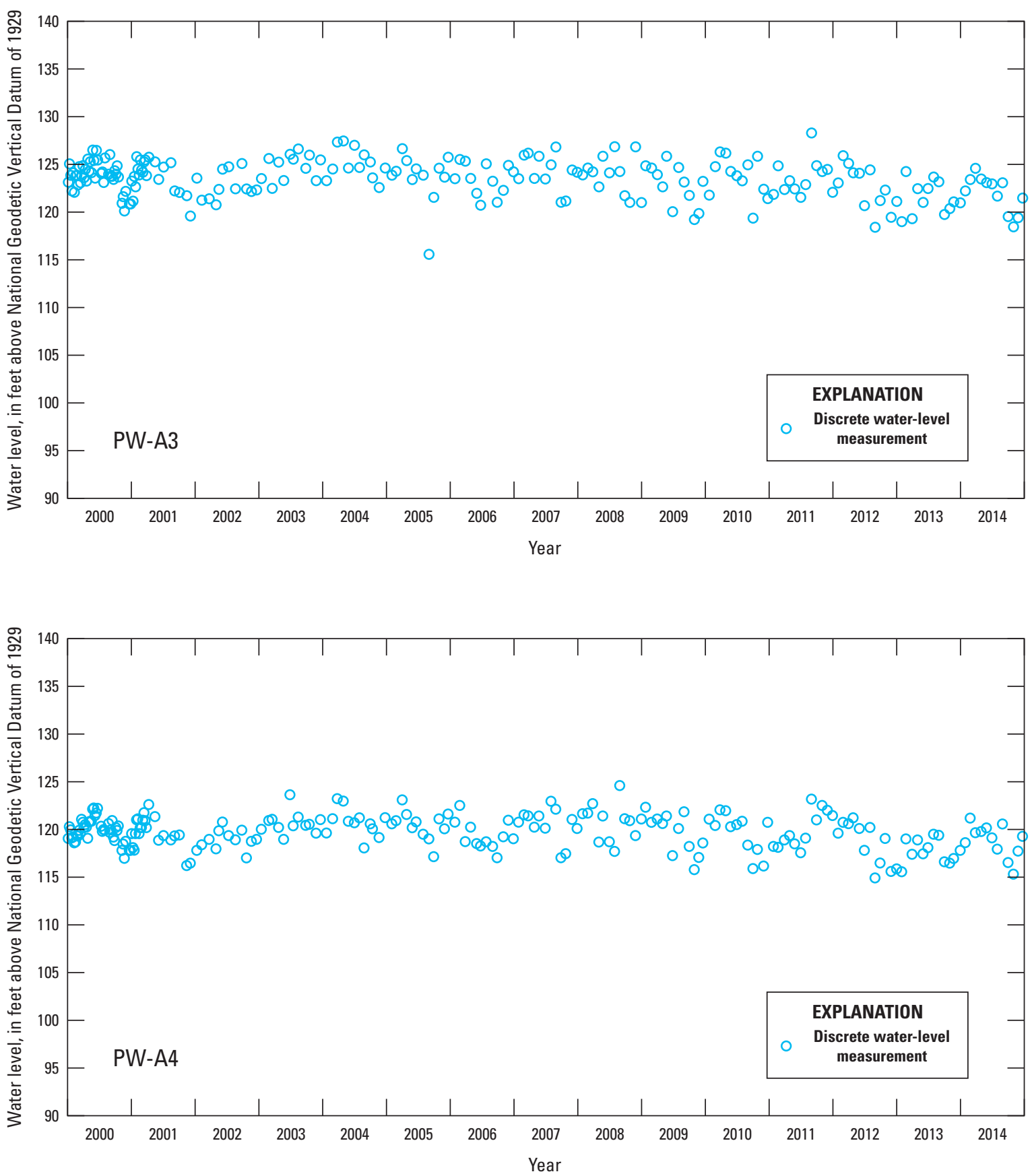

Figure 4-1. Discrete water levels in piezometer wells at the Joint Base McGuire-Dix-Lakehurst Land Application Site, New Jersey, as measured by site operators from January 2000-December 2014. - Continued 

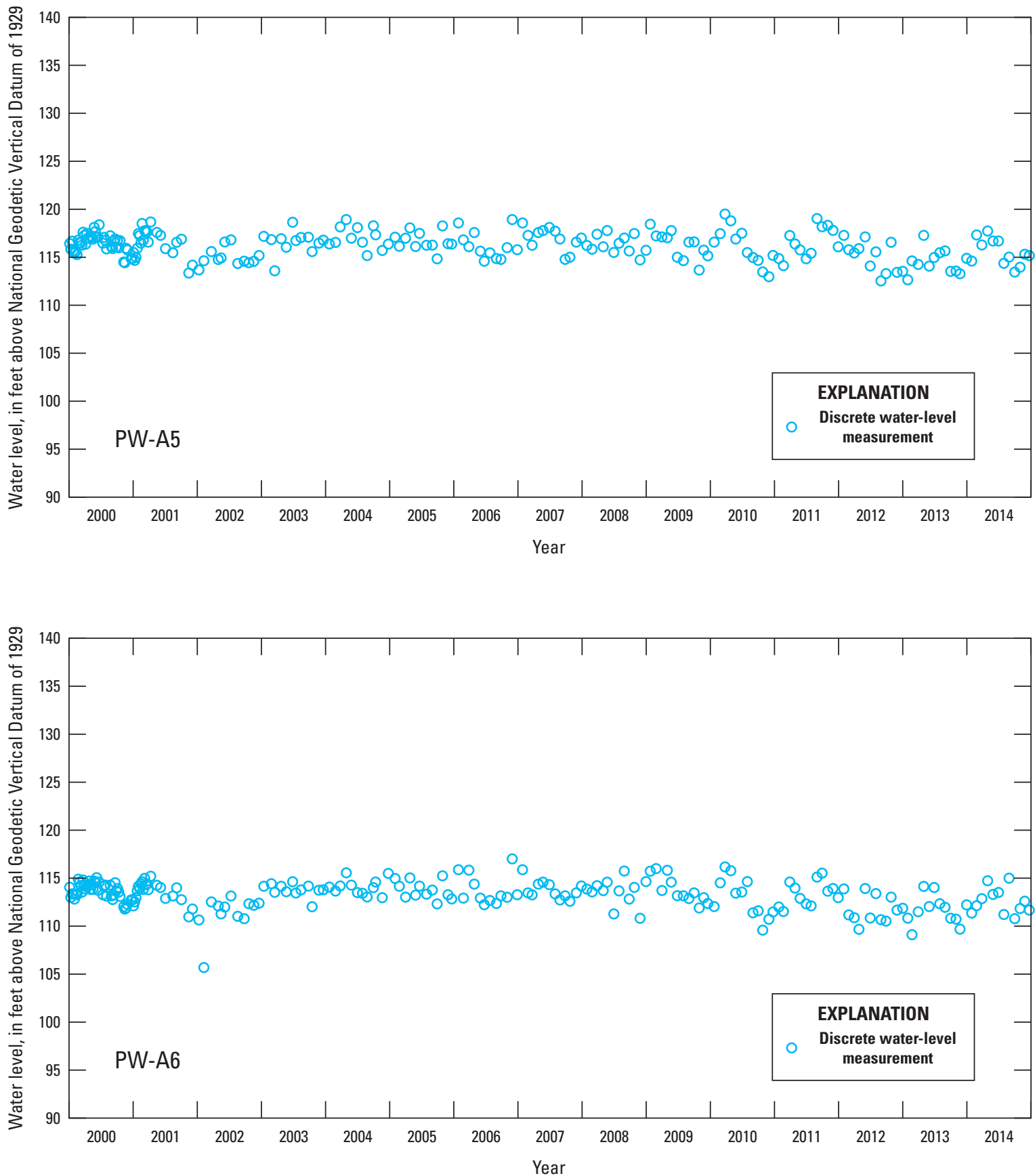

Figure 4-1. Discrete water levels in piezometer wells at the Joint Base McGuire-Dix-Lakehurst Land Application Site, New Jersey, as measured by site operators from January 2000-December 2014._Continued 

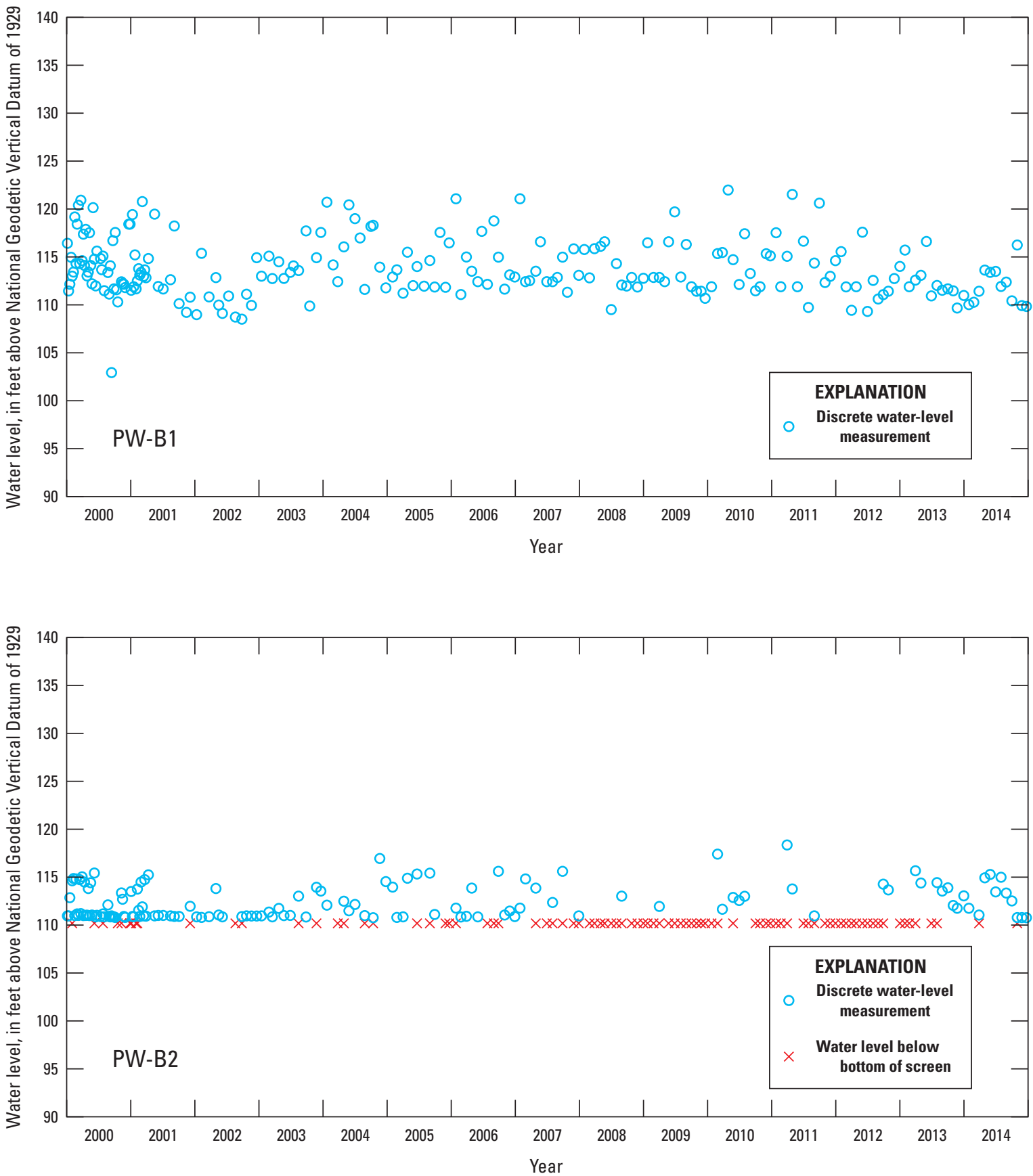

Figure 4-1. Discrete water levels in piezometer wells at the Joint Base McGuire-Dix-Lakehurst Land Application Site, New Jersey, as measured by site operators from January 2000-December 2014.-Continued 

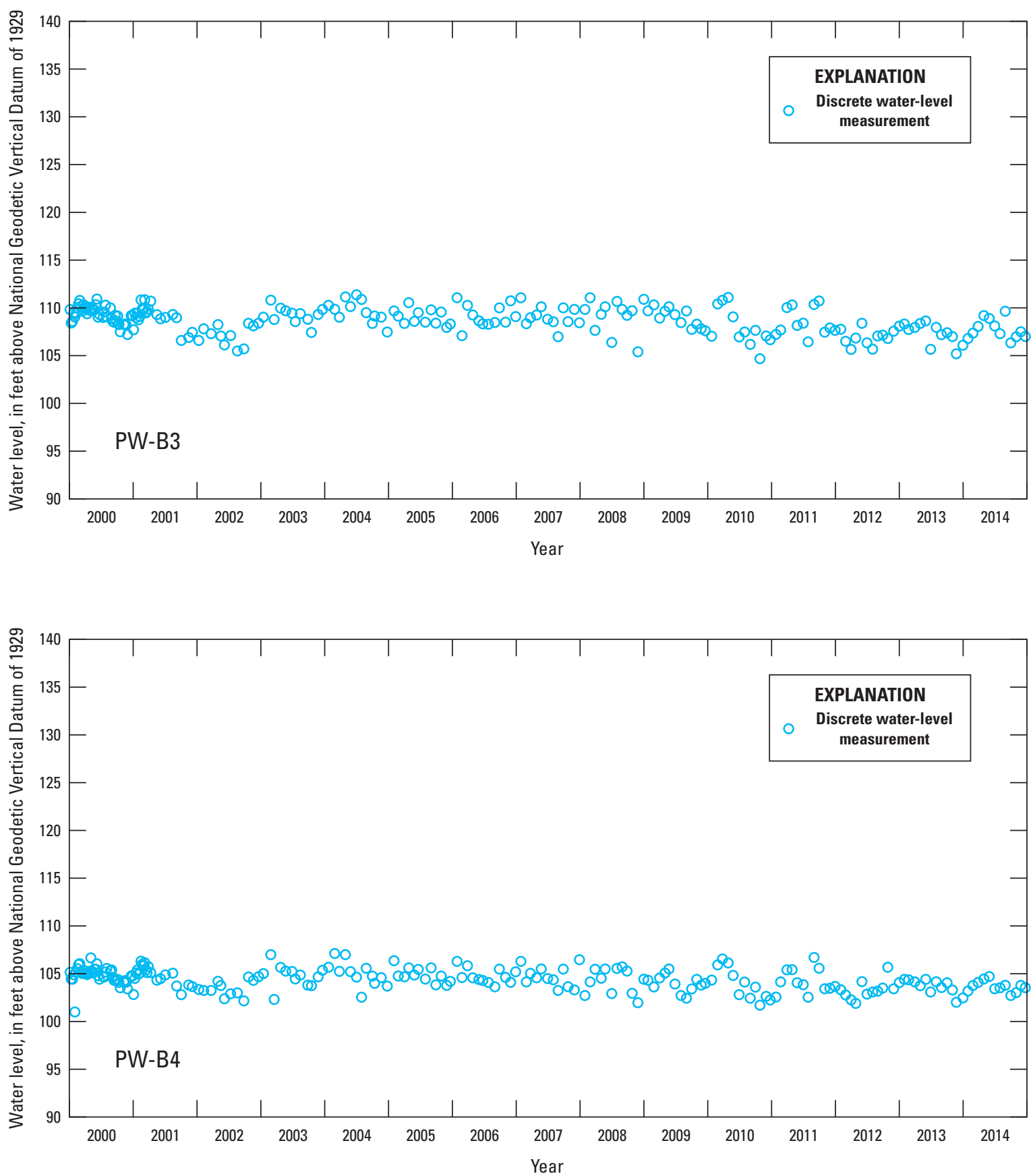

Figure 4-1. Discrete water levels in piezometer wells at the Joint Base McGuire-Dix-Lakehurst Land Application Site, New Jersey, as measured by site operators from January 2000-December 2014.—Continued 

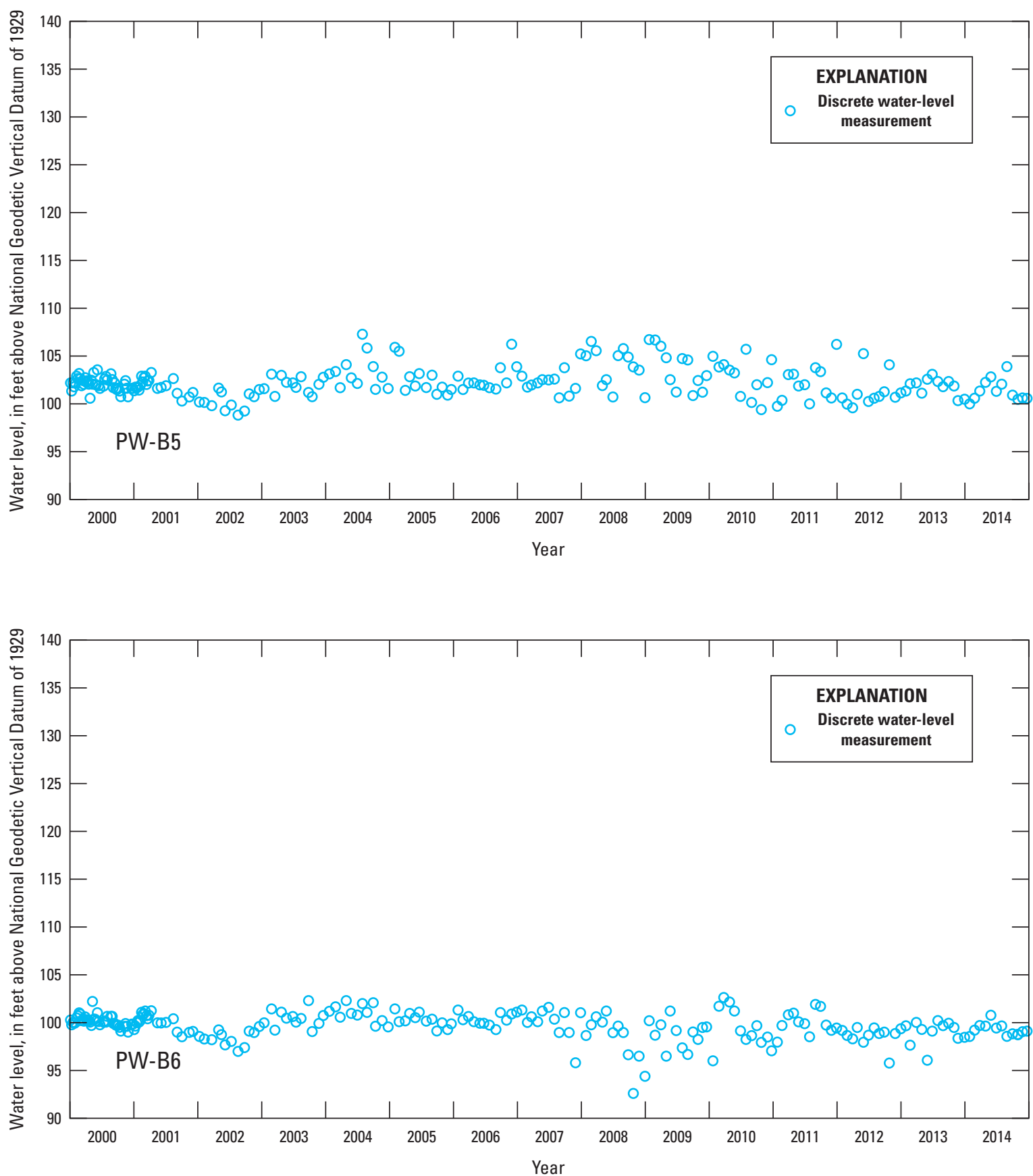

Figure 4-1. Discrete water levels in piezometer wells at the Joint Base McGuire-Dix-Lakehurst Land Application Site, New Jersey, as measured by site operators from January 2000-December 2014. - Continued 

For additional information:

Director

U.S. Geological Survey

3450 Princeton Pike, Suite 110

Lawrenceville, NJ 08648

http://nj.usgs.gov/ 
$x_{2} \sin ^{5}$

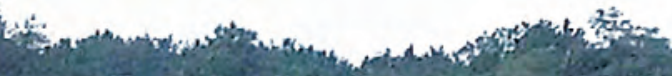

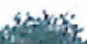

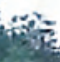

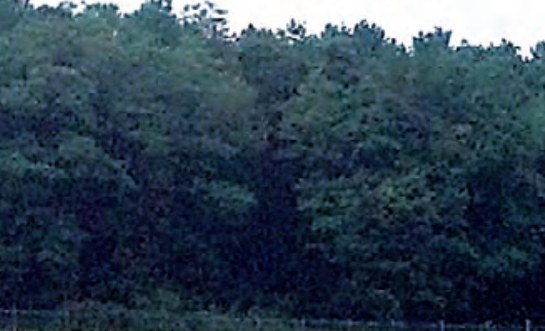

7.

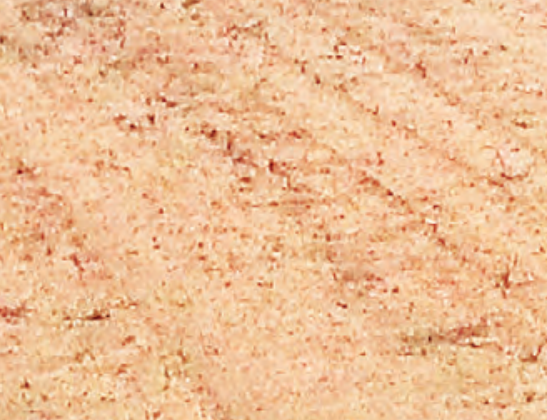

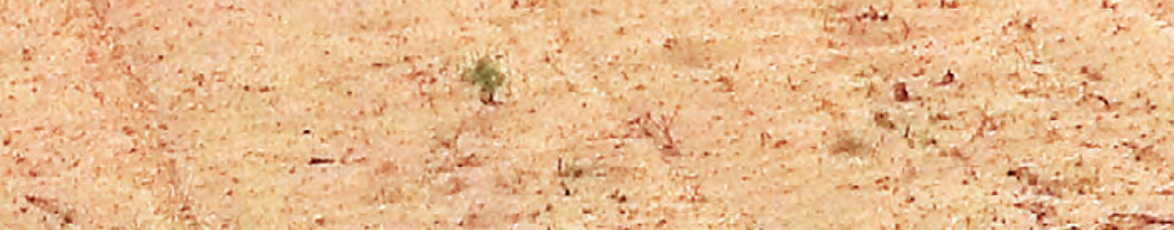

5.5

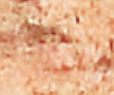

it.

$3-4$ 